The Effects of Management Practices on Grassland BirdsGrasshopper Sparrow (Ammodramus savannarum)

Chapter GG of

The Effects of Management Practices on Grassland Birds

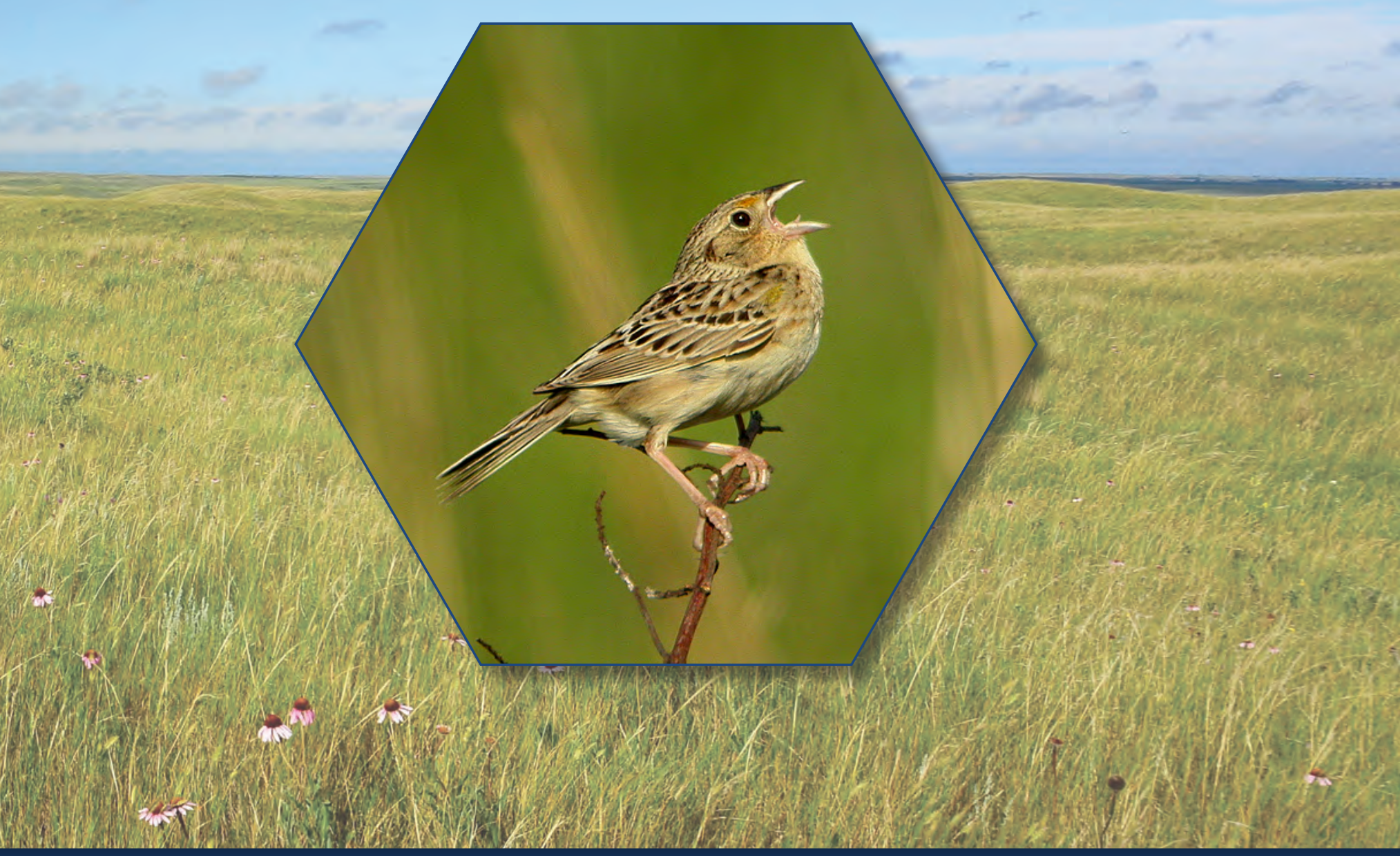

Professional Paper 1842-GG

U.S. Department of the Interior U.S. Geological Survey 
Cover. Grasshopper Sparrow. Photograph by David 0. Lambeth, used with permission. Background photograph: Northern mixed-grass prairie in North Dakota, by Rick Bohn, used with permission. 


\section{The Effects of Management Practices on Grassland Birds-Grasshopper Sparrow (Ammodramus savannarum)}

By Jill A. Shaffer, 'Lawrence D. Igl,' Douglas H. Johnson,' Marriah L. Sondreal, ${ }^{1}$ Christopher M. Goldade, ${ }^{1,2}$ Melvin P. Nenneman, ${ }^{1,3}$ Travis L. Wooten, ${ }^{1,4}$ and Betty R. Euliss ${ }^{1}$

Chapter GG of

The Effects of Management Practices on Grassland Birds

Edited by Douglas H. Johnson,' Lawrence D. Igl, ' Jill A. Shaffer, and John P. DeLong ${ }^{1,5}$

\footnotetext{
${ }^{1}$ U.S. Geological Survey.

${ }^{2}$ South Dakota Game, Fish and Parks (current).

${ }^{3}$ U.S. Fish and Wildlife Service (current).

${ }^{4}$ San Diego Zoo Institute for Conservation Research (current).

${ }^{5}$ University of Nebraska-Lincoln (current).
}

Professional Paper 1842-GG 


\section{U.S. Geological Survey, Reston, Virginia: 2021}

For more information on the USGS - the Federal source for science about the Earth, its natural and living resources, natural hazards, and the environment-visit https://www.usgs.gov or call 1-888-ASK-USGS.

For an overview of USGS information products, including maps, imagery, and publications, visit https://store.usgs.gov.

Any use of trade, firm, or product names is for descriptive purposes only and does not imply endorsement by the U.S. Government.

Although this information product, for the most part, is in the public domain, it also may contain copyrighted materials as noted in the text. Permission to reproduce copyrighted items must be secured from the copyright owner.

Suggested citation:

Shaffer, J.A., Igl, L.D., Johnson, D.H., Sondreal, M.L., Goldade, C.M., Nenneman, M.P., Wooten, T.L., and Euliss, B.R., 2021, The effects of management practices on grassland birds-Grasshopper Sparrow (Ammodramus savannarum), chap. GG of Johnson, D.H., Igl, L.D., Shaffer, J.A., and DeLong, J.P., eds., The effects of management practices on grassland birds: U.S. Geological Survey Professional Paper 1842, 57 p., https://doi.org/10.3133/pp1842GG.

ISSN 2330-7102 (online) 


\section{Contents}

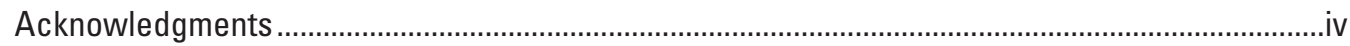

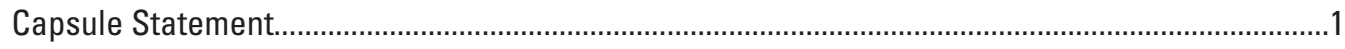

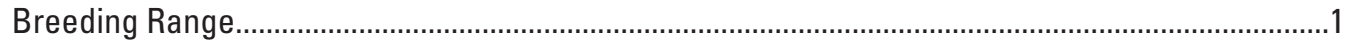

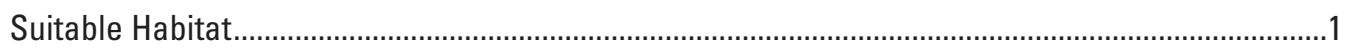

Area Requirements and Landscape Associations ..........................................................................11

Brood Parasitism by Cowbirds and Other Species ........................................................................15

Breeding-Season Phenology and Site Fidelity ..........................................................................15

Species' Response to Management..............................................................................................16

Management Recommendations from the Literature ..................................................................27

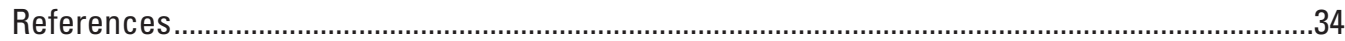

\section{Figure}

GG1. Map showing the breeding distribution of the Grasshopper Sparrow (Ammodramus savannarum) in the United States and southern Canada, based on North American Breeding Bird Survey data, 2008-12.

\section{Table}

GG1. Measured values of vegetation structure and composition in Grasshopper Sparrow (Ammodramus savannarum) breeding habitat by study ....................................................53 


\section{Conversion Factors}

International System of Units to U.S. customary units

\begin{tabular}{lll}
\hline \multicolumn{1}{c}{ Multiply } & By & \multicolumn{1}{c}{ To obtain } \\
\hline decimeter $(\mathrm{dm})$ & Length & inch (in.) \\
centimeter $(\mathrm{cm})$ & 3.937 & inch (in.) \\
millimeter $(\mathrm{mm})$ & 0.3937 & inch (in.) \\
meter $(\mathrm{m})$ & 0.03937 & foot (ft) \\
kilometer $(\mathrm{km})$ & 3.281 & mile (mi) \\
\hline & 0.6214 & \\
\hline square meter $\left(\mathrm{m}^{2}\right)$ & Area & acre \\
hectare $($ ha) & 0.0002471 & acre \\
square kilometer $\left(\mathrm{km}^{2}\right)$ & 2.471 & acre \\
square meter $\left(\mathrm{m}^{2}\right)$ & 247.1 & square foot $\left(\mathrm{ft}^{2}\right)$ \\
hectare $($ ha) & 10.76 & square mile $\left(\mathrm{mi}^{2}\right)$ \\
square kilometer $\left(\mathrm{km}^{2}\right)$ & 0.003861 & square mile $\left(\mathrm{mi}^{2}\right)$ \\
\hline & 0.3861 & pound (lb) \\
\hline kilogram (kg) & Mass & pound (lb) \\
megagram $(\mathrm{Mg})$ & 2.205 &
\end{tabular}

Temperature in degrees Celsius $\left({ }^{\circ} \mathrm{C}\right)$ may be converted to degrees Fahrenheit $\left({ }^{\circ} \mathrm{F}\right)$ as

$$
{ }^{\circ} \mathrm{F}=\left(1.8 \times{ }^{\circ} \mathrm{C}\right)+32 \text {. }
$$

\section{Abbreviations}

\section{2,4,5-T 2,4,5-Trichlorophenoxyacetic acid}

AUM animal unit month

BBS Breeding Bird Survey

CREP Conservation Reserve Enhancement Program

CRP Conservation Reserve Program

DDE dichlorodiphenyldichloroethylene

DNC dense nesting cover

PCP Permanent Cover Program

PDSI Palmer Drought Severity Index

SPI standardized precipitation index

spp. species (applies to two or more species within the genus)

STI standardized temperature index 


\section{Acknowledgments}

Major funding for this effort was provided by the Prairie Pothole Joint Venture, the U.S. Fish and Wildlife Service, and the U.S. Geological Survey. Additional funding was provided by the U.S. Forest Service, The Nature Conservancy, and the Plains and Prairie Potholes Landscape Conservation Cooperative. We thank the following cooperators who provided access to their bibliographic files: Louis B. Best, Carl E. Bock, Brenda C. Dale, Stephen K. Davis, James J. Dinsmore, James R. Herkert, Fritz L. Knopf (deceased), Rolf R. Koford, David R.C. Prescott, Mark R. Ryan, David W. Sample, David A. Swanson, Peter D. Vickery (deceased), and John L. Zimmerman (deceased). We thank Christopher M. Goldade for his illustration of the Grasshopper Sparrow and the U.S. Geological Survey's Eastern Ecological Science Center, Laurel, Maryland, for providing the range map. We thank Courtney L. Amundson, Joel S. Brice, Rachel M. Bush, James 0. Church, Shay F. Erickson, Silka L.F. Kempema, Emily C. McLean, Susana Rios, Bonnie A. Sample, and Robert O. Woodward for their assistance with various aspects of this effort. Lynn M. Hill and Keith J. Van Cleave, U.S. Geological Survey, acquired many publications for us throughout this effort, including some that were very old and obscure. Earlier versions of this account benefitted from insightful comments from William E. Jensen, Nicholas L. Rodenhouse, and Brian A. Tangen. 



\title{
The Effects of Management Practices on Grassland Birds-Grasshopper Sparrow (Ammodramus savannarum)
}

\author{
By Jill A. Shaffer, ${ }^{1}$ Lawrence D. Igl, ${ }^{1}$ Douglas H. Johnson, ${ }^{1}$ Marriah L. Sondreal, ${ }^{1}$ Christopher M. Goldade, ${ }^{1,2}$ \\ Melvin P. Nenneman, ${ }^{1,3}$ Travis L. Wooten, ${ }^{1,4}$ and Betty R. Euliss ${ }^{1}$
}

\section{Capsule Statement}

The key to Grasshopper Sparrow (Ammodramus savannarum) management is providing large areas of contiguous grassland of intermediate height with moderately deep litter and low shrub density. Grasshopper Sparrows have been reported to use habitats with $8-166$ centimeters $(\mathrm{cm})$ average vegetation height, $4-80 \mathrm{~cm}$ visual obstruction reading, 12-95 percent grass cover, 4-40 percent forb cover, less than $(<) 35$ percent shrub cover, less than or equal to $(\leq) 38$ percent bare ground, 5-61 percent litter cover, and $\leq 9 \mathrm{~cm}$ litter depth. The descriptions of key vegetation characteristics are provided in table GG1 (after the "References" section). Vernacular and scientific names of plants and animals follow the Integrated Taxonomic Information System (https://www.itis.gov).

\section{Breeding Range}

Grasshopper Sparrows breed from southern British Columbia to southern Ontario, Quebec, and Maine and south to southern California, south-central Texas, and Florida (National Geographic Society, 2011). A detailed description of the Grasshopper Sparrow breeding, winter, and year-round distributions are provided in Ruth (2015). The relative densities of Grasshopper Sparrows in the United States and southern Canada, based on North American Breeding Bird Survey (BBS) data (Sauer and others, 2014), are shown in figure GG1 (not all geographic places mentioned in report are shown on figure), which indicates that highest densities occur in the Great Plains, from North Dakota south to northern Texas, and east to northern Missouri.

\footnotetext{
${ }^{1}$ U.S. Geological Survey.

${ }^{2}$ South Dakota Game, Fish and Parks (current).

${ }^{3}$ U.S. Fish and Wildlife Service (current).

${ }^{4}$ San Diego Zoo Institute for Conservation Reseach (current).
}

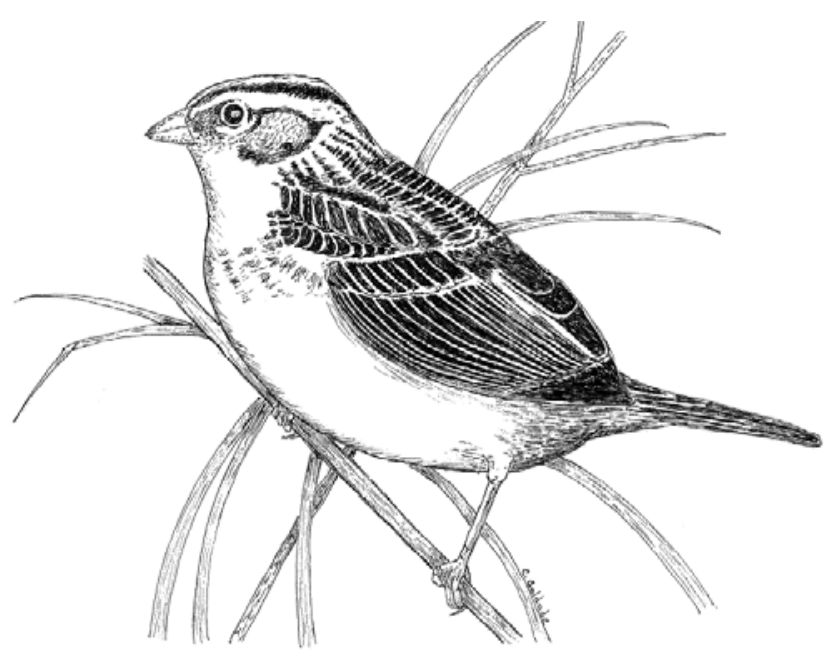

Grasshopper Sparrow. Illustration by Christopher M. Goldade, U.S. Geological Survey.

\section{Suitable Habitat}

Grasshopper Sparrows prefer grasslands of intermediate height and moderately deep litter and generally are associated with clumped vegetation interspersed with patches of bare ground (Smith, 1963, 1968; Wiens, 1969, 1970; Blankespoor, 1980; Kahl and others, 1985; Arnold and Higgins, 1986; McMaster and Davis, 2001; Vickery, 2020). Grasshopper Sparrows seem to avoid areas with tall, dense, or excessively shrubby habitats (Smith, 1968; Whitmore, 1981; Laubach, 1984; Sample, 1989; Herkert, 1991; Patterson and Best, 1996; Winter, 1998; Grant and others, 2004; Hubbard and others, 2006; Igl and others, 2008; Greer, 2009; Jacobs and others, 2012).

Grasshopper Sparrows breed in a variety of habitats, including native bunchgrass grasslands, semiarid grasslands and shrubsteppe, and sagebrush (Artemisia species [spp.]) (Walcheck, 1970; Janes, 1983; Bock and Webb, 1984; Vander Haegen and others, 2000; Rao and others, 2008; Earnst and others 2009; Holmes and Miller, 2010; Earnst and Holmes, 2012; Roberts and others, 2012; Holcomb and others, 2014; Miller and others, 2017; Andersen and Steidl, 2019, 2020); and shortgrass, mixed-grass, and tallgrass prairies that are 


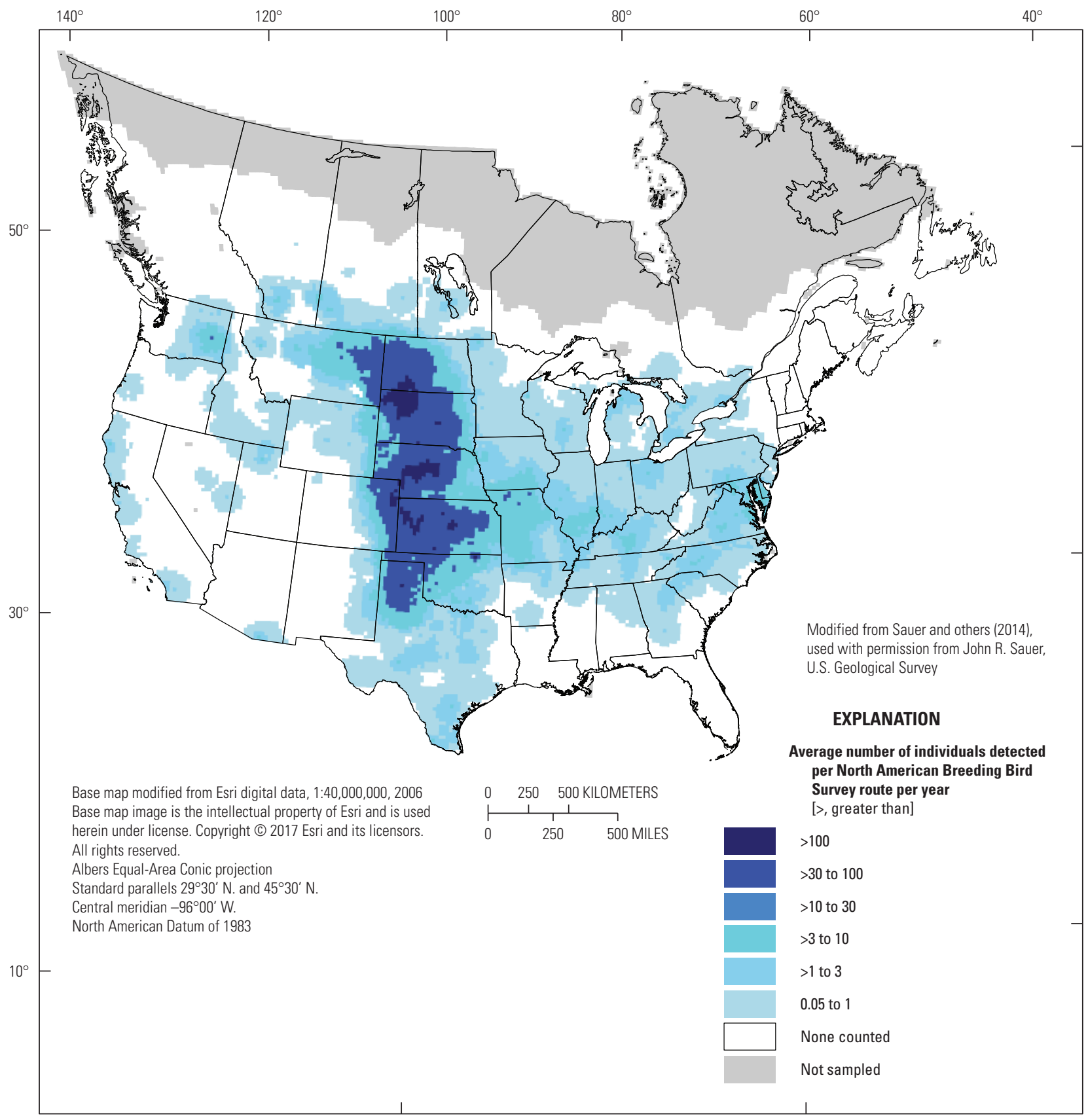

Figure GG1. The breeding distribution of the Grasshopper Sparrow (Ammodramus savannarum) in the United States and southern Canada, based on North American Breeding Bird Survey (BBS) data, 2008-12. The BBS abundance map provides only an approximation of breeding range edges.

idle, burned, hayed, or grazed (Wiens, 1970, 1973; Knapton, 1979; Kantrud, 1981; Renken, 1983; Zimmerman and Finck, 1983; Laubach, 1984; Sample, 1989; Johnson and Temple, 1990; Prescott, 1997; Zimmerman, 1997; Bock and others, 1999; Jensen, 1999; Chapman and others, 2004; Powell, 2006; Jones and others, 2010; Pillsbury and others, 2011; Jacobs and others, 2012; Richardson, 2012; Roberts and others, 2012; Davis and others, 2016a,b; Lipsey and Naugle, 2017; Igl and others, 2018; Sliwinski and others, 2020). The species also breeds in transition zones between prairies and woodlands, such as dry sand prairies in oak (Quercus spp.) savannas and oak barrens, sand shinnery oak (Quercus havardii), honey mesquite (Prosopis glandulosa) mottes, and saw palmetto (Serenoa repens) (Delany and others, 1995; Cunningham and Johnson, 2006; Smythe, 2006; Vos and Ribic, 2011, 2013; Wood and others, 2011; Bielfelt, 2013; Ruth, 2015). The species uses tame grasslands (Smith, 1963; Harrison, 1974; Bollinger, 1988) and reclaimed surface mines (Whitmore, 1980; Piehler, 1987; Galligan and others, 2006; Ingold and others, 2010). Planted cover, such as Conservation 
Reserve Program (CRP) grasslands, Conservation Reserve Enhancement Program (CREP) fields, dense nesting cover (DNC), Waterfowl Production Areas, and Permanent Cover Program (PCP) fields, also provide suitable habitat (Renken and Dinsmore, 1987; Johnson and Schwartz, 1993a, 1993b; Johnson and Igl, 1995; Klute, 1994; Berthelsen and Smith, 1995; Patterson and Best, 1996; Delisle and Savidge, 1997; Koford, 1999; McMaster and Davis, 2001; Igl, 2009; Wentworth and others, 2010; Adams and others, 2013).

Grasshopper Sparrows occasionally inhabit cropland, such as corn (Zea mays), wheat (Triticum spp.), and oat (Avena spp.) fields, but at lower densities than found in grassland habitats (Smith, 1963, 1968; Ducey and Miller, 1980; Basore and others, 1986; Faanes and Lingle, 1995; Johnson and Igl, 1995; Best and others, 1997; Lokemoen and Beiser, 1997; McLachlan, 2007; Igl and others, 2008). Grasshopper Sparrows occur at low densities in colonies of black-tailed (Cynomys ludovicianus) and white-tailed (Cynomys leucurus) prairie dogs (Clark and others, 1982; Agnew and others, 1986), but the species tends to be more abundant in adjacent shortgrass and mixed-grass prairies unoccupied by prairie dogs (Agnew and others, 1986; Smith and Lomolino, 2004; Duchardt and others, 2018, 2019; Geaumont and others, 2019). Grasshopper Sparrows rarely are associated with wetlands or wetland edges (Igl and others, 2017).

Grasshopper Sparrows use native and tame grasslands (Kendeigh, 1941; Birkenholz, 1973; Whitmore, 1979; Sample, 1989; Madden, 1996; Igl and others, 2008). Within the sagebrush communities of the Columbia Basin of Washington, northern Oregon, and Idaho, Vander Haegen and others (2000), Holmes and Miller (2010), Earnst and Holmes (2012), and Miller and others (2017) reported that Grasshopper Sparrows were more abundant in native plant communities with little invasion by tame species than in native communities highly invaded by tame species or in predominantly tame vegetation communities, whereas in the Snake River Plain ecoregion of Idaho, Rockwell and others (2021) reported the opposite finding. In the Columbia Basin, Grasshopper Sparrows were most common in native bunchgrass grasslands (primarily Sandberg's bluegrass [Poa secunda] and needle and thread [Hesperostipa comata]) and preferred sagebrush (primarily Wyoming big sagebrush [Artemisia tridentata subspecies wyomingensis]) with an understory of native bunchgrasses rather than big sagebrush with an understory of tame cheatgrass (also known as downy brome [Bromus tectorum]) (Earnst and Holmes, 2012). Holmes and Miller (2010) reported similar results, although the grasslands in their study were dominated by bluebunch wheatgrass (Pseudoroegneria spicata); Grasshopper Sparrows were most abundant in native grasslands and least abundant in sagebrush communities invaded by cheatgrass. Transitions from native grass or native sagebrush communities to tame grass or sagebrush communities with tame grassland understories resulted in greatly diminished numbers of Grasshopper Sparrows. Vander Haegen and others (2000) determined that, although Grasshopper Sparrows were more likely to occur in native grasslands, soil type and range condition (as measured by percentage cover of climax vegetation on study sites and ranked as good, fair, or poor) of vegetation communities did not affect Grasshopper Sparrows. No significant differences in Grasshopper Sparrow abundance were detected among loamy, sandy, or shallow soils and range conditions of good, fair, and poor. In the Snake River Plain of southeastern Idaho, Rockwell and others (2021) studied the use by Grasshopper Sparrows of three habitats: natural sagebrush habitats with a native-grass understory, sagebrush with a tame grass understory of primarily crested wheatgrass (Agropyron cristatum), and sites dominated by crested wheatgrass. Grasshopper Sparrows were more abundant in the crested wheatgrass habitat than in the sagebrush habitats. In Idaho, restoring sagebrush habitats from crested wheatgrass-dominated sites would decrease Grasshopper Sparrow occupancy (Rockwell and others, 2021).

Within the Canadian Prairie Provinces, Davis and Duncan (1999), Davis and others (2016b), and Wilson and Belcher (1989) reported that Grasshopper Sparrows were more abundant in tame than in native plant communities. In southcentral Saskatchewan tame and native pastures, occurrence of Grasshopper Sparrows was higher in pastures with monotypic stands of crested wheatgrass and pastures with crested wheatgrass and other tame grasses (such as smooth brome [Bromus inermis] and bluegrass [Poa spp.]) than in native mixed-grass pastures, and higher in pastures of monotypic crested wheatgrass than in pastures with crested wheatgrass and alfalfa (Medicago sativa) (Davis and Duncan, 1999). Grasshopper Sparrow occurrence was positively associated with crested wheatgrass, thickspike wheatgrass (Elymus macrourus), bluegrass, and needlegrass (Nassella spp., Hesperostipa spp.) (Davis and Duncan, 1999). In southern Saskatchewan, Grasshopper Sparrows were more abundant in tame grasslands and tame hayland than in native pastures (Davis and others, 2016b). Mean number of Grasshopper Sparrow young per nest and per successful nest did not differ between tame pastures and tame hayland. In southwestern Saskatchewan, Grasshopper Sparrow abundance did not differ between lightly grazed stands of crested wheatgrass and lightly grazed mixed-grass prairies (Sutter and Brigham, 1998). In tame and native grasslands in Manitoba, Grasshopper Sparrow abundance was positively correlated with tame Kentucky bluegrass (Poa pratensis) and negatively correlated with native species such as junegrass (Koeleria macrantha) (Wilson and Belcher, 1989).

Within the northern Great Plains in the United States, Madden and others (2000), Grant and others (2004), Schneider (1998), and Bakker and Higgins (2009) indicated a high likelihood of use by Grasshopper Sparrows for grasslands with a component of tame grass species. In periodically burned mixed-grass prairies in northwestern and north-central North Dakota, Madden and others (2000) reported that Grasshopper Sparrow occurrence was positively associated with tame grasses (smooth brome, Kentucky bluegrass, and quackgrass [Elymus repens]), and Grant and others (2004) found that the percentage cover of Kentucky bluegrass and smooth brome was higher in grasslands occupied by Grasshopper Sparrows 
The Effects of Management Practices on Grassland Birds - Grasshopper Sparrow (Ammodramus savannarum)

than in unoccupied grasslands. Occurrence was not related to percentage cover of native grass and forb species or to tame legumes such as sweet clover (Melilotus spp.). In a third study in mixed-grass pastures in North Dakota, abundance of Grasshopper Sparrows was positively associated with plant communities dominated by shrubs and tame grasses and with plant communities dominated by Kentucky bluegrass and native grasses (green needlegrass [Nassella viridula], needle and thread, blue grama [Bouteloua gracilis], junegrass, and little bluestem [Schizachyrium scoparium]) (Schneider, 1998). Abundance was negatively associated with plant communities dominated solely by native grasses. In eastern South Dakota and western Minnesota, Grasshopper Sparrow densities were similar among native tallgrass prairies and fields planted to cool- and warm-season seeding mixtures, monotypic stands of native switchgrass (Panicum virgatum), and monotypic stands of tame wheatgrass (Bakker and Higgins, 2009).

Grasshopper Sparrow response to native versus tame grasslands is more variable in the tallgrass prairie, desert grasslands, and coastal prairie ecoregions. In southern Iowa, daily nest survival of Grasshopper Sparrows was negatively associated with the abundance of cool-season grass coverage within 5 meters (m) of nests (Hovick and others, 2012). In northwestern Iowa, Kendeigh (1941) reported that the species preferred areas of restored prairie and was absent in stands of Kentucky bluegrass. Conversely, in northern Illinois, Grasshopper Sparrows occurred only in stands of Kentucky bluegrass, which had drier soils and lower foliage coverage at $30 \mathrm{~cm}$, than in nearby native prairies (Birkenholz, 1973). In southern Illinois, Grasshopper Sparrows were most abundant in fields with annual weeds dominated by foxtail (Setaria spp.) and daisy fleabane (Erigeron strigosus), followed by fields that were grazed or mowed cool-season grasses, grazed warm-season grasses, idle cool-season grasses, mowed warmseason grasses, burned cool-season grasses, and idle warmseason grasses (Walk and Warner, 2000).

In southeastern Arizona desert grasslands, Andersen and Steidl (2020) examined the response of Grasshopper Sparrows along a gradient of dominance ranging from 0 to 100 percent of total grass cover for two tame species of lovegrass, Lehmann lovegrass (Eragrostis lehmanniana) and weeping lovegrass (Eragrostis curvula), to examine whether structural differences between nonnative plants and the native plants that they displaced can alter the quantity of habitat available to animals, especially species with narrow habitat breadths. During the first 2 weeks of the settlement period, Grasshopper Sparrows established breeding territories on plots dominated by native grasses, which tended to be shorter and less dense but more structurally heterogeneous and floristically diverse than areas dominated by either tame species. As the settlement period progressed and native-dominated areas became occupied by conspecifics, Grasshopper Sparrows increasingly established territories in areas dominated by Lehmann lovegrass, which is more structurally similar to native grasses than weeping lovegrass, but did not establish territories on plots where weeping lovegrass exceeded 21 percent of grass cover.
Andersen and Steidl (2020) suggested that Grasshopper Sparrows preferred areas dominated by native plants in the absence of conspecific competition, and that the species may have perceived areas dominated by Lehmann lovegrass as suitable breeding habitat and areas dominated by weeping lovegrass as unsuitable breeding habitat. In coastal sand and southern Texas plains communities, Bielfelt (2013) examined the response of Grasshopper Sparrows across a gradient of dominance of tanglehead (Heteropogon contortus), a native grass species with growth characteristics of an invasive plant that is becomingly increasingly prevalent in southern Texas, especially in areas with clay loam soils. Grasshopper Sparrow presence and density remained stable along the dominance gradient ranging from 0 to 60 percent absolute cover.

Several researchers have compared Grasshopper Sparrow use of conservation fields planted to native and tame species of grasses relative to other habitats such as native prairies. In southern Wisconsin, Blank and others (2014) evaluated Grasshopper Sparrow use of cropland and bioenergy (or biomass) plantings, including grassland monocultures of warm-season grass species, grass-dominated grasslands (that is, greater than $[>] 50$ percent live vegetation cover in warmseason grass species), and forb-dominated grasslands (that is, $<50$ percent live vegetation cover). Grasshopper Sparrows were not present in cropland and occurred at low densities in forb-dominated grasslands, moderate densities in grass monocultures, and highest densities in grass-dominated grasslands. In another Wisconsin study, Grasshopper Sparrow densities were significantly higher in remnant prairies than in coolseason CRP grasslands, pastures, grass and alfalfa hayland, or strip crops (that is, corn or soybeans [Glycine max] alternated with alfalfa hayland, oats, or wheat); densities in prairies were 10 times higher than in strip crops (Ribic and others, 2009a). Densities were significantly higher in pastures than in either strip crops or CRP grasslands, and the species did not occur in alfalfa haylands. In central Iowa, Grasshopper Sparrows were significantly more abundant in CRP fields planted to tame grass species and alfalfa than in row-crop fields, and the species only nested within CRP grasslands (Patterson and Best, 1996). Nests were found exclusively in smooth brome or orchard grass (Dactylis glomerata) litter. In western Iowa and eastern Nebraska, Grasshopper Sparrow density was higher in warm-season conservation grasslands than in cool-season grasslands, and the level of diversity of the seeding mixture (low, medium, or high) did not affect Grasshopper Sparrow densities (Cox and others, 2014). In southeastern Nebraska, King and Savidge (1995) reported that Grasshopper Sparrow abundance was similar among prairie and CRP fields planted to cool-season grass species or to warm-season grass species, but their findings may have been confounded by haying and burning on some fields. In northern and western Missouri, Grasshopper Sparrow densities were higher in grazed native and tame pastures and hayfields than in cool- or warm-season CRP grasslands (Jacobs and others, 2012). In north-central Missouri, Grasshopper Sparrows were more abundant in CRP fields planted to cool-season grasses than in fields planted to 
warm-season grasses, but nest success was similar in the two habitats (McCoy and others, 2001). Mean fecundity likely was adequate to maintain the populations, and both planting types likely supported source populations (McCoy and others, 1999, 2001).

Within the Kansas Flint Hills ecoregion in which CRP fields were planted to native, warm-season species of grasses, Grasshopper Sparrows were significantly less abundant within CRP fields than within native pastures (Klute and others, 1997). Klute and others (1997) did not find any Grasshopper Sparrow nests within CRP fields, and Rahmig and others (2009) reported too few nests within CRP fields to run statistical analyses. Conversely, Hull and others (1996) reported that Grasshopper Sparrows were common in Kansas CRP fields and successfully nested within them. Within CRP fields located west of the Kansas Flint Hills ecoregion and planted to monocultures of tame yellow bluestem (Bothriochloa ischaemum), Grasshopper Sparrows were as abundant within CRP fields as within native or tame grasslands (Hickman and others, 2006). In north-central Oklahoma, George and others (2013) reported that Grasshopper Sparrows were more abundant in CRP fields planted to monocultures of yellow bluestem than in native mixed-grass prairies. In another north-central Oklahoma study, Chapman and others (2004) found no difference in Grasshopper Sparrow abundance between native mixed-grass prairies and CRP fields planted to yellow bluestem. In the Texas Panhandle, Grasshopper Sparrows were equally abundant in CRP fields planted to several native grass species (sideoats grama [Bouteloua curtipendula], blue grama, green sprangletop [Leptochloa dubia], switchgrass, and buffalograss [Bouteloua dactyloides]) as in fields planted to tame grass species (weeping lovegrass and yellow bluestem) (Thompson and others, 2009). In the Southern High Plains of the Texas Panhandle, nest densities within native and tame CRP grasslands did not differ by cover type (blue grama-sideoats grama, blue grama-kleingrass [Panicum coloratum], and blue grama-yellow bluestem) (Berthelsen, 1989; Berthelsen and Smith, 1995).

In central Ohio, Grasshopper Sparrow abundance did not differ between Wildlife Production Areas planted to switchgrass, a native warm-season grass, and those planted to timothy (Phleum pratense), a tame cool-season grass (Hull, 2002). In pastures and hayland planted to either cool- or warm-season grass species in Pennsylvania, Grasshopper Sparrow abundance was higher in warm-season grasslands (Giuliano and Daves, 2002). In Pennsylvania CREP grasslands, Grasshopper Sparrow density was positively associated with the proportion of cool-season grasses (Wentworth and others, 2010).

Numerous studies have evaluated the effects of vegetation structure and composition on Grasshopper Sparrow distribution and abundance. Within the sagebrush steppe community of the Columbia Basin in Idaho, Miller and others (2017) reported that the probability of Grasshopper Sparrow occupancy increased as species of perennial grasses and forbs increased. In Alberta, Manitoba, and Saskatchewan fields enrolled in the PCP, Grasshopper Sparrow presence was positively associated with the number of clumped grass contacts $0-10 \mathrm{~cm}$ above ground, standing dead vegetation contacts $20-30 \mathrm{~cm}$ above ground, and the interaction between ecoregion and clumped grass contacts $20-30 \mathrm{~cm}$ above ground (McMaster and Davis, 2001). Presence was negatively associated with number of contacts of broad-leaved grasses and forbs $0-10 \mathrm{~cm}$ above ground and with latitude. In mixedgrass prairies in southern Saskatchewan, Grasshopper Sparrow occurrence was negatively related to the density of live grasses 30-40 cm above the ground (Davis, 2004). In Saskatchewan tame and native pastures, Grasshopper Sparrow occurrence was positively associated with vegetation height (Davis and Duncan, 1999). In another study in mixed-grass prairies of Saskatchewan, Grasshopper Sparrows were most abundant where vegetation was about $12 \mathrm{~cm}$ tall and coverage of grasses was high (Kalyn Bogard and Davis, 2014). In southwestern Saskatchewan, Grasshopper Sparrow abundance increased with increasing vegetation height-density; Grasshopper Sparrow abundance decreased with increasing plant species richness and increasing heterogeneity of vegetation structure (Henderson and Davis, 2014).

In mixed-grass prairies in northeastern Montana, Grasshopper Sparrow abundance was positively related to coverage of grass, forbs, and small clubmoss (Selaginella densa) and negatively related to bare ground cover (Lipsey and Naugle, 2017). Abundance was positively related to maximum vegetation height, litter depth, and several parameters measuring vegetation density (total vegetation, live, dead, $<10 \mathrm{~cm}$, $10-20 \mathrm{~cm},>20 \mathrm{~cm}$, and grass). In mixed-grass prairies in northeastern Montana and western North Dakota, Grasshopper Sparrow abundance was maximized at about 10 percent bare ground cover, $15 \mathrm{~cm}$ residual grass height, and $3 \mathrm{~cm}$ litter depth (Vold and others, 2019). In mixed-grass prairies in northwestern North Dakota, Grasshopper Sparrow occurrence increased with decreasing visual obstruction (vegetation height-density) and increasing frequency of broad-leaved, tame species of grasses (Madden and others, 2000). In northcentral North Dakota mixed-grass prairies, Grasshopper Sparrows were present in grasslands with low coverage of live vegetation (Grant and others, 2004). Occurrence was not related to litter depth, maximum vegetation height, or year. Indicated pairs declined as coverage of leafy spurge (Euphorbia esula) increased (Grant and others, 2010). Within grazed mixed-grass prairies in North Dakota, abundance of Grasshopper Sparrows was positively associated with percentage of grass cover, litter depth, visual obstruction, and vegetation density (Schneider, 1998). Abundance was negatively associated with percentage cover of small clubmoss. The strongest vegetational predictors of the presence of Grasshopper Sparrows were decreasing small clubmoss coverage, decreasing bare ground, and increasing litter. In DNC grasslands and in mixed-grass prairies in North Dakota, territories were located in areas with shorter vegetation than unused areas, and densities were negatively correlated with litter depth and effective vegetation height (Renken, 1983). In tallgrass prairies in southeastern North Dakota, Grasshopper Sparrow abundance 
The Effects of Management Practices on Grassland Birds - Grasshopper Sparrow (Ammodramus savannarum)

was lowest at intermediate levels of litter-depth variability (Ahlering and Merkord, 2016). In CRP fields in Montana, North Dakota, South Dakota, and Minnesota, Grasshopper Sparrow abundance was lower where legumes were more common (Johnson and Schwartz, 1993b). In mixed-grass and tallgrass prairies managed by the U.S. Fish and Wildlife Service in Montana, North Dakota, South Dakota, and Minnesota, Grasshopper Sparrow densities declined with increasing visual obstruction and increasing cover of bare ground (Igl and others, 2018).

In South Dakota mixed-grass prairies, Grasshopper Sparrow occurrence was positively related to litter depth and negatively related to vegetation height-density and effective leaf height (Bakker and others, 2002). Also in South Dakota, Grasshopper Sparrows were more abundant in grassland communities that were in late seral stages than in early seral stages (Fritcher and others, 2004). In another study in South Dakota mixed-grass prairies, competitive models explaining densities of Grasshopper Sparrow singing males included only local vegetation variables, which were inconsistent among competitive models (Greer and others, 2016). Occurrence of Grasshopper Sparrows was negatively associated with visual obstruction, litter coverage, and litter depth, depending on the model (Greer, 2009; Greer and others, 2016). In restored prairies in South Dakota, Grasshopper Sparrows nested in areas with decreased vertical and horizontal plant density and effective plant height (Blankespoor, 1980). In Nebraska, abundance was positively related to litter and grass coverage and negatively related to vertical density and litter depth (Delisle and Savidge, 1997).

In portions of Colorado, Kansas, Montana, Nebraska, Oklahoma, South Dakota, Texas, Wisconsin, and Wyoming, abundance of Grasshopper Sparrows was positively correlated with percentage grass cover, percentage litter cover, total number of vertical vegetation hits, effective vegetation height, maximum height of vegetation hits, and litter depth; abundance was negatively correlated with percentage bare ground, amount of variation in litter depth and average height of forbs and shrubs, and horizontal variation in forb and shrub height (Rotenberry and Wiens, 1980). In Colorado, Montana, New Mexico, Oklahoma, South Dakota, and Texas, Grasshopper Sparrows preferred sites with tall, emergent (that is, extends above overall canopy) vegetation, and a high proportion of plant material $>10 \mathrm{~cm}$ tall (Wiens, 1973). In tallgrass pastures, the species occupied grazed areas with shorter vegetation, less litter, and a higher density of forbs than unused areas (Wiens, 1973). In CRP grasslands in Colorado, Kansas, Nebraska, and Oklahoma, Grasshopper Sparrow abundance was highest when $>75$ percent of the grass was taller than $15 \mathrm{~cm}$ (McLachlan, 2007). In tallgrass prairies of Nebraska and Iowa, Grasshopper Sparrow density and occurrence were positively related to shrub density (McLaughlin and others, 2014). Mean vegetation height was negatively related to Grasshopper Sparrow density but not related to occurrence. In tallgrass prairies in Oklahoma, Grasshopper Sparrow abundance was negatively related to vegetation height (Coppedge and others, 2008). In tallgrass prairies in northeastern Oklahoma, Grasshopper Sparrow abundance decreased with increasing litter depth (Hovick and others, 2015).

Within organic farm fields in the central Great Plains, Quinn and others (2012) reported that Grasshopper Sparrow abundance was higher at avian survey points with greater vegetation height, lower at points with greater vegetation density, and unaffected by coverage of bare ground and total vegetation cover. Grasshopper Sparrow abundance was higher at avian survey points with contiguous patches of grassland within $50 \mathrm{~m}$ and unaffected by percentage of linear patches of grassland or by linear or contiguous patches of woodland. Grasshopper Sparrow abundance was lower at avian survey points with higher percentage of corn within $50 \mathrm{~m}$ of survey points and unaffected by percentage of alfalfa, small grains, or soybeans. In Wisconsin grasslands, areas unoccupied by Grasshopper Sparrows had lower forb density and greater forb height, vegetation density, and litter depth than occupied areas (Wiens, 1969). Sample (1989) found that abundance of Grasshopper Sparrows in Wisconsin grasslands was positively correlated with percentage of bare ground, plant species richness, number of dead stems 3-6 $\mathrm{m}$ tall, and percentage of woody cover 3-6 m tall, and was negatively correlated with maximum vegetation height and vegetation height-density. In unharvested switchgrass CRP fields in Wisconsin, Grasshopper Sparrows occupied fields with the lowest vegetation height-densities (Roth and others, 2005). In pastures in southwestern Wisconsin, Grasshopper Sparrow abundance was negatively associated with percent live vegetation in each of the 3 years of the study (Renfrew and Ribic, 2008). In remnant tallgrass prairies in Minnesota, Elliott and Johnson (2017) reported a negative relationship between Grasshopper Sparrow density and visual obstruction and litter depth. The relationship between Grasshopper Sparrow density and coverage of bare ground was curvilinear; Grasshopper Sparrow density peaked at 8 percent bare ground coverage. Grasshopper Sparrow density declined with increasing vegetation height, especially up to about $45 \mathrm{~cm}$. In CRP grasslands in Iowa, abundance of Grasshopper Sparrows was negatively correlated with vertical cover of vegetation, and the species was most abundant in CRP fields with moderate grass height (shorter than $50 \mathrm{~cm}$ ) and vertical cover $(<30 \mathrm{~cm})$ (Patterson and Best, 1996). In restored tallgrass prairies in Iowa, Grasshopper Sparrow densities were negatively correlated with total vegetation coverage and vertical vegetation density (Fletcher and Koford, 2002). In Iowa pastures, postfledging survival rates of Grasshopper Sparrows were best predicted by age, whereas vegetation features such as forb abundance and vegetation height had negative but nonsignificant effects (Hovick and others, 2011). In Illinois, Grasshopper Sparrow densities were negatively correlated with mean grass height, mean vegetation height, and total number of live and dead vegetation contacts (Herkert, 1991). In Illinois grasslands, the best predictor of Grasshopper Sparrow density was height of dead vegetation; densities increased with decreasing vegetation height (Buxton and Benson, 2016). 
In Missouri grasslands, including hayed and grazed native and tame grasslands and idle CRP grasslands, Grasshopper Sparrow abundance decreased as vegetation heightdensity and litter depth increased (Jacobs and others, 2012). Counts of Grasshopper Sparrows decreased 70 percent and 79 percent over the range of increasing litter depth and vegetation height-density, respectively. In Missouri tallgrass prairies, density of Grasshopper Sparrows decreased with increasing vegetation height (Winter, 1998), and occurrence was negatively correlated with litter and positively associated with drier prairie fragments, areas containing a variety of moisture conditions, and prairie patch quality (that is, an index of the degree of native plant diversity relative to the amount of weed and brush coverage) (Swengel and Swengel, 2001).

In reclaimed coal mines in Indiana, Grasshopper Sparrows were positively associated with vegetation density, and the species was more common in grass-dominated than in forb-dominated sites (Scott and others, 2002). In a second study of reclaimed coal mines in Indiana, Grasshopper Sparrows occurred in habitats of open grasslands and shrubsavanna areas (defined as grasslands with many scattered young trees and shrubs) (Galligan and others, 2006). Nest success was positively associated with vegetation height within $1 \mathrm{~m}$ of the nest. In reclaimed surface mines in West Virginia, territories had sparser vegetation, lower grass forb coverage, lower vegetation height, and higher bare ground coverage than nonterritorial areas (Whitmore, 1981). In Pennsylvania CREP grasslands, Grasshopper Sparrow density was positively associated with amount of bare ground and negatively associated with vegetation density and variation in vegetation density (Wentworth and others, 2010). In New York, Grasshopper Sparrows used hayland characterized by relatively short, sparse, patchy, grass-dominated vegetation with greater litter coverage (Bollinger, 1995). In grassland barrens in Maine, abundance was positively correlated with higher coverage of grasses and forbs (Vickery and others, 1994).

Grasshopper Sparrows are generally considered woodland-intolerant species (Grant and others, 2004), but the species occupies grasslands in oak savanna and oak barren habitats (Rao and others, 2008). Grasshopper Sparrows also tolerate a moderate degree of short-statured shrubs within native prairies (Arnold and Higgins, 1986; Schneider, 1998; Henderson and Davis, 2014). The paragraphs immediately below describe Grasshopper Sparrow response to woody vegetation structure within a habitat patch. The effects of woody vegetation from the perspective of area, edge, and fragmentation issues are covered in the "Area Requirements and Landscape Associations" section. Grasshopper Sparrow response to the presence, encroachment, or removal of woody vegetation in grasslands is discussed in the "Species' Response to Management" section.

Within the Columbia Basin of Washington, Earnst and Holmes (2012) indicated that sagebrush cover was an important variable for predicting where Grasshopper Sparrow abundance would be low. In central and southern Idaho shrubsteppe, Grasshopper Sparrow occupancy was negatively related to shrub cover and height (Miller and others, 2017). In the arid grasslands of southeastern Arizona, Andersen and Steidl (2019) found that Grasshopper Sparrows were not present in grasslands once velvet mesquite (Prosopis velutina) cover exceeded 10 percent. Lloyd and others (1998) recorded no Grasshopper Sparrows in Arizona desert grasslands invaded by velvet mesquite. However, in another southeastern Arizona study, Bock and Bock (1992) reported that Grasshopper Sparrow abundance was positively related to shrub cover (on a field site that was included in the Andersen and Steidl [2019] study). Also in southeastern Arizona, Ruth and others (2020) found that shrubs were used by Grasshopper Sparrows as air temperature in desert grasslands increased. Ruth and others (2020) documented the use of shrubs as thermal refugia during periods of extremely high temperatures, such as when the difference between ground temperature in direct sun and ground temperature beneath shrubs differed by 15 degrees Celsius $\left({ }^{\circ} \mathrm{C}\right)$.

In Alberta, Manitoba, and Saskatchewan fields enrolled in the PCP, Grasshopper Sparrow occurrence was positively related to the distance to nearest shrub (Davis, 2004). In southwestern Saskatchewan, Grasshopper Sparrow abundance increased with increasing shrub cover (Henderson and Davis, 2014). In Saskatchewan and North Dakota, Grasshopper Sparrow density was negatively related to coverage of woody vegetation (Ahlering and others, 2009). In mixedgrass prairies in northeastern Montana, Grasshopper Sparrow abundance declined linearly with shrub height and declined dramatically when wooded area within $100 \mathrm{~m}$ of avian pointcount surveys increased beyond 0 percent (Vold and others, 2019). In northeastern Montana, Grasshopper Sparrow abundance was negatively related to coverage of shrubs (Lipsey and Naugle, 2017). In north-central North Dakota mixedgrass prairies, Grasshopper Sparrow reached their maximum probability of occurrence ( $>80$ percent) in open, treeless grasslands within the study area, and the probability of occurrence declined to 50 percent at about 10-25 percent woodland cover (Grant and others, 2004). Grasshopper Sparrows were present in grasslands with low coverage of shrubs $>1 \mathrm{~m}$ tall. Indicated pairs declined as coverage of low shrubs increased (Grant and others, 2010). Grasshopper Sparrows were present more often in grasslands with low levels of quaking aspen (Populus tremuloides) woodland within $100 \mathrm{~m}$ of vegetation points than in unoccupied areas (Grant and others, 2004). In mixed-grass prairies in south-central North Dakota, Grasshopper Sparrows occurred along both shrubby and shrubless transects but were most abundant on the shrubless transects (Arnold and Higgins, 1986). Within grazed mixed-grass prairies in North Dakota, abundance of Grasshopper Sparrows was positively associated with density of low-growing shrubs (western snowberry [Symphoricarpos occidentalis] and silverberry [Elaeagnus commutata]) (Schneider, 1998). In another study in South Dakota mixed-grass prairies, occurrence of Grasshopper Sparrows was negatively associated with shrub height (Greer, 2009; Greer and others, 2016). In 
The Effects of Management Practices on Grassland Birds - Grasshopper Sparrow (Ammodramus savannarum)

portions of Colorado, Kansas, Montana, Nebraska, Oklahoma, South Dakota, Texas, Wisconsin, and Wyoming, abundance of Grasshopper Sparrows was negatively correlated with shrub height and the amount of variation in shrub height (Rotenberry and Wiens, 1980). In Oklahoma sand prairies encroached upon by eastern redcedar (Juniperus virginiana), Grasshopper Sparrow abundance decreased with increasing canopy cover of redcedar (Doxon, 2009).

In remnant tallgrass prairies in Minnesota, Elliott and Johnson (2017) reported a curvilinear relationship between Grasshopper Sparrow density and coverage of shrubs; Grasshopper Sparrow density peaked at about 4 percent shrub coverage. In Missouri grasslands, including hayed and grazed native and tame fields and idle CRP fields, Grasshopper Sparrow abundance decreased as shrub coverage increased (Jacobs and others, 2012). Counts of Grasshopper Sparrows decreased 24 percent over the range of increasing shrub coverage. In Missouri tallgrass prairies, density of Grasshopper Sparrows decreased with increasing woody plant coverage (Winter, 1998). On reclaimed surface mines in West Virginia, Grasshopper Sparrow territories had lower shrub coverage than nonterritory areas (Whitmore, 1981).

Grasshopper Sparrows may be more tolerant of woody vegetation in transitional habitats, such as savannas. Within blue oak (Quercus douglasii) and coast live oak (Quercus agrifolia) woodlands near San Francisco, California, Grasshopper Sparrows inhabited valley grasslands dominated by tame species of grasses such as annual ryegrass (Lolium multiflorum), ripgut brome (Bromus diandrus), and soft chess (Bromus hordeaceus) (Rao and others, 2008). In Wisconsin, Grasshopper Sparrows inhabited dry sand prairies dominated by little bluestem, big bluestem (Andropogon gerardii), and junegrass within a larger landscape of oak savannas (defined as 5-50 percent tree cover) and woodlands ( $>50$ percent tree cover) dominated by oak (Quercus spp.), jack pine (Pinus banksiana), and black cherry (Prunus serotina) (Vos and Ribic, 2011, 2013; Wood and others, 2011; Bar-Massada and others, 2012). In the Central Hardwoods and Cross Timbers regions of eastern and south-central Oklahoma where oak (Quercus spp.) and hickory (Carya spp.) forests are interspersed with a mosaic of tallgrass prairie pastures, hayfields, and row crops, Grasshopper Sparrows were present within grassland habitats (Crosby and others, 2015).

Grasshopper Sparrow territories may include elevated structures that are used as song perches. In desert grasslands, Ruth and Skagen (2017) reported that male Grasshopper Sparrows regularly used taller shrubs within their territories as favored song perches, a pattern that was more obvious in grasslands with low shrub densities. Ruth and Skagen (2017) suggested that there is a low threshold of shrub density acceptable to Grasshopper Sparrows, especially males, and that selecting territories and nest sites in relation to shrub density may be a balancing act. In Wisconsin, 60 percent of 73 territories included posts, 53 percent fencelines, 20 percent wire bales or tangles, and 10 percent trees (Wiens, 1969). In Iowa, the species used fence posts as song perches (Laubach,
1984), and in Michigan, the species preferred low (1.5 m), artificial perches over high (2 m) perches (Harrison, 1974).

Several researchers have examined the relationship between vegetation structure and composition and Grasshopper Sparrow nest-site selection or nest success. In Oregon shrubsteppe communities, Holmes and Miller (2010) reported that 36 of 37 Grasshopper Sparrow nests were located at the base of tall perennial bunchgrass species, such as bluebunch wheatgrass; this included nests located below isolated bunchgrass plants within stands dominated by cheatgrass. Within native bunchgrass communities in southern Arizona, Ruth and Skagen (2018) reported that nests that were more concealed by vegetation had lower daily survival rates. Ruth and Skagen (2017) also compared vegetation characteristics between Grasshopper Sparrow territories and random plots on two sites; the Davis site was managed for grazing and had a higher proportion of native grasses, a lower proportion of tame grasses, and lower shrub density than the Audubon site, which was ungrazed but occasionally exposed to wildfires (Ruth and Skagen, 2017). Above 1 decimeter, grass seemed too high and dense (as measured by visual obstruction) for Grasshopper Sparrows. Male Grasshopper Sparrows selected territories in areas of sparser vegetation (as measured by visual obstruction) with a higher density of tall ( $>2 \mathrm{~m})$ shrubs than on random plots. Vertical vegetation density, total variation around mean vertical vegetation density, standing dead litter, litter depth, total variation around the means of the litter variables, bare ground, and proportion of native and tame grasses did not differ on territories compared to random plots. At the Audubon site, where shrub density was higher, distance to the nearest shrub was lower than at the Davis site, but still the variable did not explain territory selection. Females selected native grass species for nest construction and selected sites with lower small shrub (1-2 m tall) densities than territories overall. Visual obstruction, variation around the mean visual obstruction, vertical vegetation density, total variation around mean vertical vegetation density, standing dead litter, litter depth, total variation around the means of the litter variables, bare ground, and proportion of native and tame grasses did not differ on nest plots compared to territories. Female nest-site selection was not related to the distance to the nearest shrub (Ruth and Skagen, 2017).

In mixed-grass prairies in north-central Montana, grassland patches with Grasshopper Sparrow nests were characterized by lower bare ground coverage than random areas (Dieni and Jones, 2003). The species avoided using western wheatgrass (Pascopyrum smithii) as a nesting substrate and preferred to nest under blue grama. In northeastern Montana and southwestern North Dakota, Bernath-Plaisted and others (2021) found little support that vegetation structure or composition variables affected Grasshopper Sparrow nest success. In a related study, Guido (2020) reported that Grasshopper Sparrow nest sites were associated with lower values of Green Normalized Vegetation Index (an indication of the amount of live vegetation), intermediate vegetation density, and low coverage of bare ground. In leafy spurge-infested 
tallgrass prairies in southeastern North Dakota, Grasshopper Sparrow nest success was not related to leafy spurge coverage but was positively associated with woody vegetation and litter coverage, litter depth, and vegetation height-density (Scheiman and others, 2003). Nest sites of Grasshopper Sparrows had higher percentage of nonleafy spurge forb coverage than random sites. Grasshopper Sparrow densities were lower on plots with a high leafy spurge infestation than on plots with low or medium infestations. In Wisconsin, daily nest survival rates declined as the proportion of litter or forbs at the nest site increased and as nests were placed farther from tree rows (Ribic and others, 2012). In Wisconsin CRP fields, Byers and others (2017) found no relationship between daily nest survival rates and measured vegetation characteristics around nests. In Iowa, nests characterized by high litter coverage and fescue (Festuca spp.) were more likely to be depredated by mammals and snakes (Lyons and others, 2015). Mammals were less likely to prey on Grasshopper Sparrow nests surrounded by high forb coverage. Neither vegetation density at the nest nor landscape variables (distance to woodland, grassland, water bodies, agricultural fields, or edges) were related to nest loss by any predator taxon (Lyons and others, 2015).

Within tallgrass prairies at the eastern margins of the Flint Hills of Kansas, nest sites $\left(0.25\right.$ square meter $\left[\mathrm{m}^{2}\right]$ around nests) had significantly less bare ground and greater live grass coverage than areas $1-10 \mathrm{~m}$ around nests (Jensen, 1999). In another study within the Kansas Flint Hills, no significant differences in vegetation between nest sites and random sites were found; in general, Grasshopper Sparrow nest sites were characterized by low vegetation, litter, and height-density, and moderate coverage of bare ground (Hubbard and others, 2006). In a third study within the Kansas Flint Hills, Winnicki and others (2020) reported that nest success was positively related to vegetation height and negatively related to percentage forb cover. In the Flint Hills in Kansas and Oklahoma, Frey and others (2008) found that nest survival increased as litter and grass coverage increased, and nest survival decreased as the season progressed.

Vegetation structure and composition also may be important for juvenile Grasshopper Sparrows during the postfledging period. In northeastern Montana and southwestern North Dakota, Bernath-Plaisted and others (2021) reported that juvenile survival decreased with increasing coverage of dead grass. In Maryland CRP fields, dependent fledgling Grasshopper Sparrows were more likely to be located at sites with higher coverage of bare ground and litter and higher plant species richness than at random sites (Small and others, 2015). Dependent young were found in sites averaging 16 percent less bare ground coverage, 17 percent more total vegetation coverage, 7 percent more forb coverage, and 11 percent more warm-season grass coverage than were independent young. Independent young were found at sites with more bare ground coverage than at random sites.

Slope, topography, or elevation may affect Grasshopper Sparrow abundance and nest survival. In Oregon native bunchgrass communities, Janes (1983) recorded eight
Grasshopper Sparrow territories on slopes ranging from 0 to 23 percent. In Idaho shrubsteppe, Grasshopper Sparrow occupancy peaked at intermediate levels of elevation, in which the range of elevation was 913-2,323 m (Miller and others, 2017). In Colorado, Grasshopper Sparrow abundance was not significantly different between upland (mixed-grass prairies) and lowland (tallgrass prairies or tame hayland) grasslands (Bock and others, 1999). In southeastern North Dakota, Grasshopper Sparrow abundance was higher in the deltaic plains landform dominated by tallgrass prairies than in choppy high sand dunes dominated by oak savanna or hummocky sandhills dominated by prairie and wetlands (Ahlering and Merkord, 2016). In western North Dakota, Grasshopper Sparrow densities declined with increasing slope (Chepulis, 2016). Throughout the Flint Hills of Kansas and Oklahoma, Frey and others (2008) examined the effect of topography on daily nest survival. Although Grasshopper Sparrows generally nested on slopes, topographic position was less important to daily nest survival than nesting chronology and vegetation structure around nest sites. In a Wisconsin study, abundance of Grasshopper Sparrows was higher on expansive, treeless upland pastures than on lowland, riparian pastures in forested valleys in 1 of 2 years and was positively associated with the upland/lowland status of pastures and percentage of bare ground (Renfrew and Ribic, 2002).

Prevailing wind direction during the breeding season may affect nest orientation. In the Flint Hills in Kansas and Oklahoma, Long and others (2009) reported that the entrances of 333 Grasshopper Sparrow nests were significantly nonrandom and primarily oriented to the northeast. The prevailing wind during the breeding season was from the south, and the nests were generally oriented downwind; the orientation of the nest entrances shifted northward or eastward as the nesting season progressed and coincided with a southeastward shift in prevailing wind direction. In Kentucky, Sutter and Ritchison (2005) did not examine slope or topography but noted that Grasshopper Sparrow nests were primarily oriented to the northwest, north, northeast, or east, explaining that prevailing winds on the study area caused vegetation to bend toward the east-northeast. Likewise, 64 percent of 15 nests in a Wisconsin study were oriented to the north or northeast (Wiens, 1969).

Spatial and temporal variation in precipitation and temperature may affect the occurrence, abundance, and distribution of Grasshopper Sparrows. Moisture levels may affect the distribution and abundance of Grasshopper Sparrows, but as Niemuth and others (2017) stated, the biological meaning of climate variables in models characterizing bird-environment relationships is unclear; climate variables are likely correlates of other factors (for example, plant community composition, primary and secondary productivity) that more directly affect species occurrence, likely in concert with other factors such as soils and landform. The future distribution and average dates of phenological events such as spring arrival date of Grasshopper Sparrows may be affected by climateinduced changes to temperature and precipitation (Butler, 
2003; Langham and others, 2015). Butler (2003) found that although the average spring arrival date for Grasshopper Sparrows in New York had not significantly changed between the time periods 1903-50 and 1951-93, the spring arrival date was about 15 days earlier in Massachusetts. Under projected greenhouse gas emission scenarios described by the Intergovernmental Panel on Climate Change (2000), Langham and others (2015) categorized the Grasshopper Sparrow as a climate-stable species, indicating that the species would retain $>50$ percent of its current distribution by 2050 across all Intergovernmental Panel on Climate Change scenarios, with potential for range expansion. Wilsey and others (2019) compiled avian occurrence data from 40 datasets to project climate vulnerability scores under scenarios in which global mean temperature increases $1.5,2$, or $3{ }^{\circ} \mathrm{C}$. Grasshopper Sparrows ranked neutral in vulnerability during the breeding season at $1.5{ }^{\circ} \mathrm{C}$ and $2{ }^{\circ} \mathrm{C}$ increases and ranked low at a $3{ }^{\circ} \mathrm{C}$ increase.

Within California's Central Coast ecoregion, Shaw and others (2012) modeled projected changes in the distribution of Grasshopper Sparrows owing to climate change; the models projected that climatically suitable areas for Grasshopper Sparrow declined at all decadal steps through 2050; by 2100 , there was not suitable climate space within the area for Grasshopper Sparrows. Within native bunchgrass communities in southern Arizona, Ruth and Skagen (2018) reported that daily survival rates of nests decreased with a wetter previous growing season and with large rain events on previous days. Future climate change was predicted to cause increased frequency of extreme storm events and thus reduced nest survival of Grasshopper Sparrows, but lower projected seasonal precipitation before nesting was predicted to increase nest survival.

Along the boreal forest-prairie ecotone in Alberta, Nixon and others (2016) used a combination of BBS, eBird (https:// ebird.org; Sullivan and others, 2009), and point-count data to model the impact of future climate-change scenarios on Grasshopper Sparrow breeding distribution. Nixon and others (2016) predicted that the Grasshopper Sparrow's breeding range would expand by about 10 percent and that expansion largely would occur northward, originating in the Parkland Region of Alberta, with little southward expansion. Using point-count data from five States in the northern Great Plains representing the area of the Upper Missouri River Basin and 20 environmental predictors, Baltensperger and others (2020) modeled the potential effect of seven future land-cover and climate scenarios on Grasshopper Sparrow abundance; the largest declines (25.8 individuals per square kilometer $\left[\mathrm{km}^{2}\right]$ ) were predicted to occur in the area to the east of the western borders of North Dakota and South Dakota, especially in the area between the Black Hills and the Missouri River in South Dakota. The largest increases in abundance (29.4 individuals per $\mathrm{km}^{2}$ ) were predicted in the Black Hills and upland areas of central Wyoming and Montana (Baltensperger and others, 2020). Using BBS data for four States that constitute the Badlands and Prairies Bird Conservation Region, Gorzo and others (2016) reported that Grasshopper Sparrow abundance was negatively related to a standardized temperature index for the same year and the previous year and was positively related to a within-year standardized precipitation index; however, the best model included an interaction between temperature and precipitation indices. Using BBS data for seven States that constitute the northern Great Plains, Niemuth and others (2017) developed spatially explicit models of Grasshopper Sparrow distribution from a suite of candidate predictor variables that characterized landscape, weather and climate, bird activity and detectability, topography, and survey structure. The occurrence of Grasshopper Sparrows was negatively associated with current-year and previous-year precipitation anomalies. Current-year precipitation anomaly was defined as the subtraction of current-year March-June precipitation from the long-term mean to create a variable reflecting the deviation in precipitation for this time period, and the previousyear precipitation anomaly was defined as the subtraction of previous year's precipitation from the long-term mean precipitation. The occurrence of Grasshopper Sparrows exhibited a nonlinear relationship with mean maximum temperature (that is, the mean long-term [30-year] August temperature) (Niemuth and others, 2017). Using two indices of regional moisture, the number of wetlands containing water during annual May waterfowl surveys and the Palmer Drought Severity Index [PDSI]), Niemuth and others (2008) concluded that Grasshopper Sparrow abundance was negatively associated with the number of prairie potholes in May of the same year and in May of the previous year. Dispersion (that is, percentage of 13 BBS routes on which the species was detected) of Grasshopper Sparrows was negatively associated with the current- and previous-year PDSI. In western North Dakota, density of Grasshopper Sparrows declined during one of the most severe droughts on record for the region but returned to average levels 1 year postdrought (George and others, 1992). In northeastern Montana and southwestern North Dakota, Bernath-Plaisted and others (2021) found little support that temperature and precipitation variables affected Grasshopper Sparrow nest success or juvenile survival. Ahlering and others (2009) found that Grasshopper Sparrow density was higher during wetter springs preceded by warmer winters in North Dakota and Saskatchewan. Density of Grasshopper Sparrows was positively related to concurrent May precipitation and to May-September minimum and average precipitation. Density was not related to total precipitation, total snowfall, maximum temperature, or PDSI (Ahlering and others, 2009). In a 6-year study in north-central North Dakota, Grant and others (2010) reported that Grasshopper Sparrow abundance remained low and stable for 3 years after precipitation received during the previous breeding season reached its maximum and then increased in the fourth year (a dry year and the last year of the study) after the high-precipitation event. In tallgrass prairies of southeastern North Dakota, Grasshopper Sparrow abundance tripled between consecutive wet and dry years (Ahlering and Merkord, 2016).

Using BBS data and standardized precipitation evapotranspiration index data for the South Central Semi-Arid 
Prairies ecoregion, Cady and others (2019) reported that Grasshopper Sparrow occupancy decreased with increasing drought intensity, but no local colonization or extinction probability trends in the ecoregion were related to drought conditions. Glass and others (2020) found that Grasshopper Sparrow abundance on islands within the Platte River Valley of Nebraska declined with increasing spring precipitation, but precipitation did not have a measurable effect on productivity; productivity (defined as an index based on the probability of a captured bird being a hatch-year bird) was highest in recently burned areas, but the effect of this variable decreased with increasing spring temperature. In another study along the Platte River in Nebraska, Kim and others (2008) demonstrated that Grasshopper Sparrow density in grazed pastures increased with drier conditions. Grasshopper Sparrow density was more positively correlated with PDSI values from May than with PDSI values from August, although density overall was not significantly related to PDSI levels; regional PDSI values ranged from mild drought to extremely wet (Kim and others, 2008). From an analysis of BBS data from Minnesota, Wisconsin, Michigan, Illinois, and Iowa, Thogmartin and others (2006) found that Grasshopper Sparrow abundance was affected more strongly by climatic factors than by landscape variables; abundance was affected by an index of static wetness, temperature during the warmest quarter, range in growing season temperature, mean and variation in summer precipitation, and mean and variation in autumn precipitation.

\section{Area Requirements and Landscape Associations}

Average breeding territory size for male Grasshopper Sparrows is small, usually $<2$ hectares (ha) (George, 1952; Smith, 1968; Wiens, 1969, 1970; Ducey and Miller, 1980; Laubach, 1984; Delisle, 1995; Delisle and Savidge, 1996; O'Leary and Nyberg, 2000; Jones, 2011; Williams, 2016; Ruth, 2017; Vickery, 2020). In CRP grasslands in southeastern Nebraska, Delisle and Savidge (1996) found no differences in the sizes of successful and unsuccessful male territories or for edge and interior (that is, $>100 \mathrm{~m}$ from the edge) territories; territories ranged in size from 0.36 to 1.24 ha. Within the Kansas Flint Hills, Winnicki and others (2020) examined territorial aggregation in male Grasshopper Sparrows and reported an average density of 0.77 territory per ha. In Saskatchewan mixed-grass prairies, the species' minimum area requirement was about 134 ha (Davis, 2004). In Illinois tallgrass prairies, the minimum area occupied by Grasshopper Sparrows was 10-30 ha (Herkert, 1991), although the minimum area needed to support a breeding population may be $>30$ ha (Herkert, 1994b). In wet meadows in Nebraska, the minimum area of grassland fragments occupied by Grasshopper Sparrows was 8-12 ha, with a perimeter-area ratio of 0.018 (Helzer, 1996; Helzer and Jelinski, 1999).
Several studies have reported that Grasshopper Sparrows are area sensitive (that is, show a preference for larger grasslands over smaller grasslands) (Herkert, 1994a, 1994b; Vickery and others, 1994; Bollinger, 1995; Helzer, 1996; O'Leary and Nyberg, 2000; Davis, 2004; Greer, 2009; Ribic and others, 2009b). Area sensitivity in Grasshopper Sparrows varies by region and study. Ribic and Sample (2001) cautioned that, given the difficulties with defining patch size in grasslands, such as making decisions on whether or not to include suitable grassland habitats directly adjacent to study fields in the definition of field size, and because of differences in the range of field sizes and landscape composition among studies, it is perhaps not surprising to see differing results of area sensitivity. In PCP grasslands in Alberta, Manitoba, and Saskatchewan, Grasshopper Sparrow presence was positively associated with field size (McMaster and Davis, 2001). In mixed-grass prairies in Saskatchewan, Grasshopper Sparrows were associated with large patches of native prairie (Skinner, 2004). In South Dakota, Grasshopper Sparrows exhibited area sensitivity in several studies conducted within mixed-grass prairies (Bakker and others, 2002; DeJong and others, 2004; Berman, 2007). Berman (2007) reported that Grasshopper Sparrow densities were significantly higher in large (>100 ha) patches than in small $(<50 \mathrm{ha})$ patches, regardless of the percentage of grassland habitat in the surrounding landscape. In wet meadows in Nebraska, the occurrence of Grasshopper Sparrows was positively correlated with patch area and negatively correlated with perimeter-area ratio (Helzer and Jelinski, 1999). In Wisconsin oak barrens and dry prairies, nest density and relative abundance of Grasshopper Sparrows increased as patch size increased (Vos and Ribic, 2011, 2013). In Wisconsin grasslands, Grasshopper Sparrow patch occupancy was positively related to patch area (Guttery and others, 2017). In Pennsylvania CREP grasslands, Grasshopper Sparrow density was positively associated with field area (Wentworth and others, 2010). In New York grasslands, Grasshopper Sparrow densities did not increase with field size, but fields that suffered local Grasshopper Sparrow extinctions were smaller than fields that retained Grasshopper Sparrows (Balent and Norment, 2003). The proportion of successful Grasshopper Sparrow nests was higher in large fields (8-13.2 ha) than in small fields (1.8-8 ha). Also, the mean number of young produced per female and the average yearly return rate of adult Grasshopper Sparrows tended to be higher in large fields than in small fields (Balent and Norment, 2003).

Other studies, however, have reported that area sensitivity of Grasshopper Sparrows varied regionally or temporally, or that abundance or occurrence was not related to patch size. In CRP grasslands in nine counties in North Dakota, South Dakota, Minnesota, and Montana, Johnson and Igl (2001) examined the relationship between Grasshopper Sparrow presence, frequency, and density to area of contiguous grassland and reported equivocal results. The presence, frequency, and density of Grasshopper Sparrows were negatively associated with grassland patch size in one county and positively associated in another county; in a third county, presence and 
density were positively associated with patch size. Johnson and Igl (2001) demonstrated the importance of replication in space for studies of area sensitivity; results from one area may not apply to other areas because of differences in study design, analytical methods, location relative to the range of the species, and the surrounding landscape. Using BBS data, Bohannon and Blinnikov (2019) examined the relationship between Grasshopper Sparrow abundance on BBS routes and habitat fragmentation in western North Dakota and eastern Montana caused by oil-extraction activities. The local population did not significantly decline with increasing edge density (that is, the amount of linear edge per total landscape area). In South Dakota mixed-grass prairies, Greer and others (2016) reported that the occurrence and density of Grasshopper Sparrows were not related to grassland patch area. In western South Dakota, DeJong and others (2006) reported that Grasshopper Sparrow occurrence was not related to patch size, although Grasshopper Sparrow densities were higher in larger than in smaller grasslands. In Nebraska and Iowa tallgrass prairies, Grasshopper Sparrow density and occurrence were not related to area or edge-to-interior ratio (McLaughlin and others, 2014). In Wisconsin grasslands, field size was not an important predictor of Grasshopper Sparrow density (Ribic and Sample, 2001); however, in another Wisconsin study, Grasshopper Sparrow density increased with pasture size in 1 of 2 years (Renfrew and Ribic, 2002). In Wisconsin CRP grasslands, daily nest survival rates were not related to field size (Byers and others, 2017). In tallgrass prairie fragments in southwestern Missouri, vegetation structure more strongly affected Grasshopper Sparrow density than did fragment size (Winter, 1998; Winter and Faaborg, 1999), and in another Missouri study, Grasshopper Sparrow abundance was not related to prairie patch size (Swengel and Swengel, 2001). Within the Kansas Flint Hills, Winnicki and others (2020) reported that nest success was negatively related to distance of nest to edge and distance to tree cover.

Several studies have reported that the amount of grassland surrounding a grassland patch affects Grasshopper Sparrow distribution and abundance, and that Grasshopper Sparrows prefer grasslands embedded in a landscape of other grasslands. Within the Prairie Pothole Region of Canada, Fedy and others (2018) examined the effect of grassland, cropland, shrubland, woodland, and wetland habitats at four scales (within 400; 800; 1,600; and 3,200 m of BBS stops) on the relative probability of occurrence of Grasshopper Sparrows. The best model indicated that the species preferred landscapes consisting of native and tame grassland within $1,600 \mathrm{~m}$; the model indicated avoidance of wetland basins within $400 \mathrm{~m}$ and of shrubby and wooded landscapes within 1,600 m (Fedy and others, 2018). In southwestern Manitoba, Grasshopper Sparrow abundance was positively affected by grassland amount relative to grassland configuration; the relative abundance of grassland-obligate species, including the Grasshopper Sparrow, showed a strong negative response to a landscape shape index, which quantified the amount of edge for a given land-cover class relative to that of a maximally compact and simple shape (that is, a circle) of the same area (Lockhart and Koper, 2018). In southern Saskatchewan, the abundance of Grasshopper Sparrows in hayland plots was negatively affected by increasing amounts of hayland within $400 \mathrm{~m}$ of study plots, but abundance in tame pasture plots increased with the amount of hayland in the surrounding landscape (Davis and others, 2016b). Nest survival was not affected by landscape factors.

In a study encompassing seven States of the northern Great Plains, Dreitz and others (2017) demonstrated that occupancy of Grasshopper Sparrows was positively related to latitude, percentage of grassland habitat within $1-\mathrm{km}^{2}$ survey plots, and public landownership, and was negatively related to percentage of sagebrush habitat. Niemuth and others (2017) investigated the relationship between Grasshopper Sparrow occurrence and land use within $400 \mathrm{~m}$ of BBS survey points in the U.S. portion of the northern Great Plains; Grasshopper Sparrow occurrence was positively associated with percent coverage of grasslands (native and tame), pasture and hayland (native and tame), CRP fields, alfalfa fields, and shrubland, but occurrence was negatively associated with percent coverage of forest and developed land. The species exhibited a quadratic relationship with percent coverage of cropland (Niemuth and others, 2017). Veech (2006) used North American BBS data from the U.S. portion of the Great Plains to characterize the landscape within a 30-kilometer $(\mathrm{km})$ radius of populations of Grasshopper Sparrows that were increasing or decreasing. Rangeland constituted a greater proportion of the landscape for increasing Grasshopper Sparrow populations than for decreasing populations; rangeland was defined as the natural condition of native grasses, forbs, and shrubs that were used for grazing and browsing by livestock. The proportion of CRP or urban lands did not differ between increasing and decreasing populations (Veech, 2006).

In northeastern Montana, Lipsey (2015) reported that Grasshopper Sparrow density was not affected by the amount of grassland habitat at four spatial extents $(0.7 ; 2.6$; 93 ; and $\left.1,492 \mathrm{~km}^{2}\right)$. In another study in northeastern Montana, Vold and others (2019) reported that Grasshopper Sparrow abundance decreased sharply in mixed-grass prairies when wooded area within $1,000 \mathrm{~m}^{2}$ of the avian point-count survey increased beyond 2 percent. Abundance also declined sharply with increasing fence density within $500 \mathrm{~m}^{2}$. In the Prairie Pothole Region of North Dakota, Grasshopper Sparrow abundance was positively associated with the amount of grassland within 200 and $400 \mathrm{~m}$ of survey points and negatively associated with the amount of wetland within $200 \mathrm{~m}$ of survey points (Browder and others, 2002). In North Dakota mixed-grass prairies, Grasshopper Sparrows were present in grasslands with lower coverage of quaking aspen woodlands within $500 \mathrm{~m}$ than in unoccupied grasslands (Grant and others, 2004). In tallgrass and mixed-grass prairie fragments in western Minnesota and eastern North Dakota and South Dakota, Grasshopper Sparrow occupancy was higher in prairie remnants characterized by sparse brush cover and embedded in landscapes with high herbaceous riparian patch 
density, high matrix richness and diversity, and low matrix contagion (that is, a measure of the configuration of the different landscape elements within the landscape) (Shahan and others, 2017). In South Dakota mixed-grass prairies, Grasshopper Sparrow probability of occurrence was $>70$ percent when the surrounding landscape contained 75 percent grassland habitat within $400 \mathrm{~m}$ (Greer, 2009). Male density was positively associated with the amount of grassland in the surrounding landscape up to $800 \mathrm{~m}$. However, in a later report, Greer and others (2016) concluded that the relationship between Grasshopper Sparrow occurrence or density and proportion of grassland in the surrounding landscape was not statistically strong. In wildlife management areas in southern Nebraska, Stuber and Fontaine (2018) estimated that the ideal proportion of grassland and woodland for Grasshopper Sparrows was 0.86 (at 2,000-m scale) and virtually 0 (at 1,000-m scale), respectively.

Within organic farm fields in the central Great Plains, Quinn and others (2012) reported that Grasshopper Sparrow abundance was unaffected by the percentage of grassland, woodland, or landscape vegetation heterogeneity within $5,000 \mathrm{~m}$ of avian survey points. In Wisconsin, Grasshopper Sparrow patch occupancy was positively related to pasture (mostly tame cool-season grass species), idle grasslands (including agricultural set-aside fields, oldfields [that is, idle or neglected arable lands that have naturally reverted back to perennial cover], and retired pastures, with vegetation consisting of tame cool-season or native warm-season grasses) at all scales (from 100 to 3,000 m from avian point-count surveys), negatively related to cropland at larger scales, and not related to forest or hayland at any scale (Guttery and others, 2017). In Wisconsin, Grasshopper Sparrow density was positively correlated with area of native ungrazed grasslands and pastures and with the area of grassland within a 400-m buffer around survey transects; density was negatively correlated with cover-type diversity (Ribic and Sample, 2001). In pastures in southwestern Wisconsin, the percentage of grassland within 1,200 $\mathrm{m}$ of pasture edges had moderate to high relative importance for Grasshopper Sparrow abundance compared to smaller scales (that is, 200 and $700 \mathrm{~m}$ ) (Renfrew and Ribic, 2008). In another Wisconsin study, abundance was positively correlated to proportions of idle grasslands, pastures, rowcrops, and hayland, and unrelated to the area of grassland and forest in an 800-ha landscape with high amounts of grassland and low amounts of forest (Murray and others, 2008). In a study encompassing a wide range of terrestrial and aquatic habitats throughout Iowa, Harms and others (2017) reported that Grasshopper Sparrow occupancy and colonization of the landscape were positively correlated to the percentage of the landscape in grassland within $500 \mathrm{~m}$ of sampled sites and negatively correlated with the percentage of the landscape in woodland within $1,000 \mathrm{~m}$ of sampled sites. In Iowa and Missouri, Grasshopper Sparrow density was negatively associated with grass coverage at $0-300 \mathrm{~m}$ and positively associated with grass coverage at $300-1,000 \mathrm{~m}$, a result the author could not explain (Pillsbury, 2010). In western Missouri, Jacobs and others (2012) reported that Grasshopper Sparrow abundance increased 21 percent over the increasing range of percentage of grassland within $1 \mathrm{~km}$ of avian survey points; however, the model-averaged coefficients with 95-percent confidence intervals overlapped zero. Throughout the Kansas Flint Hills, Herse and others $(2018,2020,2021)$ evaluated the role of grassland amount, edge context, and degree of fragmentation on Grasshopper Sparrow abundance at spatial scales of 200-, 400-, 800- and 1,600-m radii from avian point-count survey locations. Grasshopper Sparrow abundance was most strongly related to landscape structure within a 400-m radius of point-count surveys, responding positively and nonlinearly with percentage grassland and negatively and linearly with grassland-to-cropland and grassland-to-tree edge density. The negative response to cropland edges was a consequence of reduced grassland area, whereas the stronger negative response to woody edges was not attributable to variation in grassland area. Fragmentation and edge context mattered most in landscapes constituting 50-80 percent grassland. Fragmentation effects on the occurrence of Grasshopper Sparrows were most pronounced in landscapes comprising 50-80 percent grassland (Herse and others, 2018). In northwestern Oklahoma, species occurrence models indicated that high grassland cover within $800 \mathrm{~m}$ of BBS stops was an indicator of Grasshopper Sparrow occurrence (Coppedge and others, 2004).

In a region-wide study of the upper Great Lakes, Corace and others (2009) reported that Grasshopper Sparrow populations declined with the loss of pasture and hayland at the county scale. In Pennsylvania CREP grasslands, Grasshopper Sparrow density was positively associated with area of forest within $500 \mathrm{~m}$ and with grassland area within $5 \mathrm{~km}$ of fields in which birds were surveyed (Wentworth and others, 2010).

Several studies have evaluated the effects of cropland in the surrounding landscape on Grasshopper Sparrow abundance or distribution (for example, McMaster and others, 1999; Best and others, 2001; McLachlan, 2007; Murray and others, 2008; Niemuth and others, 2017). In southern Saskatchewan hayfields, the number of Grasshopper Sparrow pairs was not affected by amount of cropland or wetland within $1.6 \mathrm{~km}$ of study areas (McMaster and others, 1999). In Colorado, Nebraska, Kansas, and Oklahoma, Grasshopper Sparrow occurrence was positively related to the amount of dryland agricultural fields and to the number of land-cover patches in the surrounding landscape at all spatial scales examined (300; 600; 1,200; and 2,400 m) (McLachlan, 2007). In Iowa, Grasshopper Sparrow abundance was significantly correlated with relatively low amounts of rowcrops and relatively high amounts of pasture, alfalfa hayland, herbaceous fencerow, and CRP grasslands in the landscape (Best and others, 2001).

Grasshopper Sparrows are generally intolerant of woody vegetation in the surrounding landscape. In North Dakota mixed-grass prairies, Grant and others (2004) classified 
the Grasshopper Sparrow as a woodland-sensitive species. Grasshopper Sparrows occupied grasslands with lower coverage of quaking aspen woodlands within $100 \mathrm{~m}$ and within $500 \mathrm{~m}$ than in unoccupied grasslands. In another North Dakota study, Grasshopper Sparrow occurrence in tallgrass prairies was negatively associated with the presence of woodland and wetlands at the 100 -m scale and with tree cover at the 1,600-m scale (Cunningham and Johnson, 2006). In the Upper Midwest, Thogmartin and others (2006) found a negative relationship between Grasshopper Sparrow abundance and forest cover in the surrounding landscape at the 800-ha scale. In Iowa rowcrop fields only occasionally visited by Grasshopper Sparrows, the species' abundance was significantly correlated with relatively high amounts of woodland and wooded strip cover (that is, wooded fencerow, wooded roadside, and wooded riparian) in the landscape (Best and others, 2001). In Oklahoma sand sagebrush (Artemisia filifolia) grasslands, Grasshopper Sparrow abundance was negatively related to coverage of live eastern redcedar at the 200-m scale (Doxon, 2009).

Grasshopper Sparrows also may be intolerant of woody edges that border grasslands. In mixed-grass prairies in central and western South Dakota, Grasshopper Sparrow occurrence declined with increasing wooded edge; the probability of occurrence was $>75$ percent when no wooded edge was present but fell to $<15$ percent when wooded edge constituted $>75$ percent of a grassland patch (Greer, 2009; Greer and others, 2016). In mixed-grass prairies in eastern South Dakota, the occurrence of Grasshopper Sparrows decreased as the amount of woody vegetation bordering grassland patch edges increased (Bakker and others, 2002). Contrary to Bakker and others (2002), in tallgrass prairie fragments in North and South Dakota, Quamen (2007) and Tack and others (2017) reported no avoidance of field shelterbelts by Grasshopper Sparrows and found no differences in Grasshopper Sparrow abundance following the removal of shelterbelts from grasslands.

In Nebraska, Grasshopper Sparrow densities were lower within $75 \mathrm{~m}$ of wooded edges and within $50 \mathrm{~m}$ of the edges of corn fields (Helzer, 1996). Male densities were negatively associated with amount of patch edge occupied by woody species. In Nebraska CRP fields, Delisle (1995) reported that 14 of 31 male territories were classified as interior territories and 17 territories were classified as edge territories when $100 \mathrm{~m}$ was used as the criterion for defining an interior from an edge territory. Only one of the 31 territories was defined as an edge territory when $50 \mathrm{~m}$ was used as the criterion to separate interior and edge territories. For 10 Grasshopper Sparrow nests, all were placed $>50 \mathrm{~m}$ from an edge, and nest distance from an edge averaged $119 \mathrm{~m}$. Edges included roadsides, wooded draws, and fences that separated CRP fields from crop fields (Delisle, 1995). In Kansas tallgrass prairies, mean distance of Grasshopper Sparrow nests from agricultural and woodland edges was about $67 \mathrm{~m}$ (Jensen, 1999). In another Kansas study, Hubbard and others (2006) found that the distance of Grasshopper Sparrow nests to the nearest shrub or tree and to the nearest perch was significantly greater than for random sites. Mean distances of nests to the nearest shrub or tree and to perches were 40.6 and $32.8 \mathrm{~m}$, respectively. No differences were found for mean distances of nests to vehicle tracks, edges, or patches of bare ground $>1 \mathrm{~m}^{2}$. In Oklahoma tallgrass prairies, Grasshopper Sparrows displayed a strong avoidance to building nests in roadside edges cut through native prairies; only one of 274 nests occurred in roadside vegetation (Patten and others, 2006, 2011).

In Minnesota tallgrass prairie fragments, the probability of encountering Grasshopper Sparrows was highest on large (130-486 ha) fragments far ( $>45 \mathrm{~m}$ ) from a forest edge, and nest productivity was highest for Grasshopper Sparrow nests far from a forest edge (Johnson and Temple, 1986). In remnant tallgrass prairies in Minnesota, Elliott and Johnson (2017) reported that Grasshopper Sparrow densities declined as the proportion of trees within $100 \mathrm{~m}$ of survey points increased, and sparrow densities increased with increasing distance to the nearest tree. Remnant prairies with Grasshopper Sparrows were significantly farther from trees than prairies without Grasshopper Sparrows. In Wisconsin oak barrens and dry prairies, daily survival of Grasshopper Sparrow nests was higher for nests placed away from trees; the probability of fledging at least one young was 0.28 for nests away from trees and 0.05 for nests near trees (Vos and Ribic, 2013). In continuously grazed pastures dominated by cool-season grasses (primarily brome [Bromus spp.] and Kentucky bluegrass) in southwestern Wisconsin, Grasshopper Sparrow nests within $15 \mathrm{~m}$ of a woody edge had a 43 percent chance of fledging young per nest attempt, whereas nests in the center of a field (within $293 \mathrm{~m}$ of a woody edge) had a 39 percent chance of fledging young per nest attempt (Ribic and others, 2012). In tame pastures in southwestern Wisconsin, Grasshopper Sparrows had lower nest densities within $50 \mathrm{~m}$ of edges than nests in grassland interiors, regardless of adjacent land use (Renfrew and others, 2005). Predation rates were not affected by distance to edge. An edge was defined as the boundary between pasture and woodlots, hayland, CRP fields, idle grassland, cropland, woodland, or human developments (Renfrew and others, 2005). In Wisconsin CRP fields, daily nest survival rates and overall nest depredation were not related to distance to field edges (Byers and others, 2017). In grazed and ungrazed pastures in south-central Wisconsin, mean distance from a Grasshopper Sparrow territory boundary to woods was $207.8 \mathrm{~m}$, to a fence line was $24.5 \mathrm{~m}$, and to a cultivated field was $82.8 \mathrm{~m}$ (Wiens, 1969). In another Wisconsin study, the density of Grasshopper Sparrows was negatively correlated with distance of transects to hedgerows within 200- and 400-m buffers (Ribic and Sample, 2001). In Iowa burned and grazed pastures, daily survival rates were not affected by proximity to any type of edge (that is, roads, fences, woody draws, and woodland areas) (Hovick and others, 2012). The mean distance of nests to woody edges, fences, or permanent water bodies was $58.3 \mathrm{~m}$ and the greatest distance to any edge was $133 \mathrm{~m}$. In restored tallgrass prairies in Iowa, Grasshopper Sparrow densities were negatively 
correlated with the percentage of grassland-woodland edge in the surrounding landscape (Fletcher and Koford, 2002). In Iowa and Missouri, Pillsbury (2010) found that Grasshopper Sparrow densities were positively related to wooded edge density in the landscape at the two scales evaluated, $0-300 \mathrm{~m}$ and $300-1,000 \mathrm{~m}$.

\section{Brood Parasitism by Cowbirds and Other Species}

Grasshopper Sparrows generally are considered an uncommon host of the brood parasitic Brown-headed Cowbird (Molothrus ater), although the species may be moderately to heavily parasitized by cowbirds in some regions (Shaffer and others, 2019a). Rates of cowbird brood parasitism for Grasshopper Sparrows are summarized in Shaffer and others (2019a) and varied from 0 percent (several studies) to 58 percent of 12 nests (Klute, 1994; Klute and others, 1997). Grasshopper Sparrow nests may be multiply parasitized (Elliott, 1976, 1978; Davis and Sealy, 2000; Igl and Johnson, 2007). Grasshopper Sparrows are unlikely to abandon their nests after cowbird parasitism (Elliott, 1976, 1978), but they are capable of ejecting smaller artificial eggs. In response to natural and experimental nest parasitism in Illinois, Grasshopper Sparrows rejected all undersized artificial cowbird eggs but did not reject normal-sized artificial cowbird eggs (Peer and others, 2000). An artificial egg was considered rejected if the egg disappeared from an active nest (that is, ejected) or if the egg was damaged by the host (for example, pecked). In Illinois, Kansas, Missouri, North Dakota, and Oklahoma, rates of cowbird brood parasitism in Grasshopper Sparrow nests were positively associated with cowbird abundance (Herkert and others, 2003). In Manitoba, mean number of host young fledged from successful, unparasitized nests was significantly higher than the number of host young fledged from successful, parasitized nests; cowbird parasitism costs Grasshopper Sparrows about 1.3 host young per successful nest (Davis and Sealy, 2000). In Kansas, cowbird parasitism costs Grasshopper Sparrows about two young per parasitized nest (Elliott, 1976), whereas Rahmig and others (2009) estimated that 1.56 fewer young were fledged in parasitized nests than in unparasitized nests (Grasshopper Sparrow, Dickcissel [Spiza americana], and Eastern Meadowlark [Sturnella magna] combined). In another Kansas study, Winnicki and others (2020) reported that the aggregation of male Grasshopper Sparrows, reported as territory density, did not confer any protection against brood parasitism. In Oklahoma, the number of host young fledged per nest did not differ between parasitized and unparasitized nests (Reinking and others, 2009).

The effects of patch area or habitat edges on rates of cowbird brood parasitism in Grasshopper Sparrow nests are variable. In Illinois, Kansas, Missouri, North Dakota, and Oklahoma, Brown-headed Cowbird brood parasitism was not associated with patch area; however, nest depredation was negatively associated with habitat patch area (Herkert and others, 2003). In Minnesota tallgrass prairies, nest depredation and brood parasitism of Grasshopper Sparrow nests decreased farther from woody edges, and nest depredation rates were lower on large (130-486 ha) than on small (16-32 ha) grasslands (Johnson and Temple, 1990). In Kansas tallgrass prairies, rates of Brown-headed Cowbird brood parasitism were not different for Grasshopper Sparrow nests placed $<100 \mathrm{~m}$ from woodland edges compared to nests placed $>100 \mathrm{~m}$ from woodland edges; parasitism rates also were not different for nests placed $<100 \mathrm{~m}$ from agricultural edges than nests placed $>100 \mathrm{~m}$ from agricultural edges (Jensen, 1999). In Oklahoma, most landscape attributes (for example, distance to woody vegetation, proximity to edges, water, fences, perches, or livestock) had little effect on Grasshopper Sparrow parasitism rates (Patten and others, 2006, 2011). Nests placed on grass clumps above $14 \mathrm{~cm}$ were parasitized more heavily than nests below this height. Parasitism rates were higher in prairies that were burned and grazed than prairies that were only grazed or that were undisturbed (Patten and others, 2006, 2011).

\section{Breeding-Season Phenology and Site Fidelity}

Grasshopper Sparrows arrive on their breeding grounds in mid-April and depart for the wintering grounds in mid-September (George, 1952; Smith, 1968; Harrison, 1974; Stewart, 1975; Laubach, 1984; Vickery, 2020). In Saskatchewan and Manitoba, the species arrives later (mid-May) and departs earlier (August) than in southern areas of their range (Knapton, 1979). On reclaimed surface mines in Pennsylvania, the earliest nest initiation for Grasshopper Sparrows was May 12 and the latest known fledging date was August 11; 20 percent of nest initiations occurred after July 1 (Stauffer and others, 2011). Throughout most of their range, Grasshopper Sparrows can produce two broods, one in late May and a second in early July (George, 1952; Smith, 1968; Williams and Boyle, 2019; Vickery, 2020). However, in the northern part of its range, one brood is probably more common (Jones and others, 2010). In Maine, no territories showed evidence of successfully fledging two broods (Vickery and others, 1992). In Wisconsin, double broods were uncommon (Wiens, 1969), but in Michigan, double broods have been observed (Harrison, 1974). Grasshopper Sparrows frequently renest after nest failure and, if unsuccessful in previous attempts, may renest three or more times during the breeding season (Vickery, 2020). On a reclaimed surface mine in West Virginia, the average number of nesting attempts by Grasshopper Sparrows over 3 years ranged from 3.5 to 4.8 attempts per year (Wray and others, 1982). Small and others (2009) documented the first records of polygyny for this species, whereas Kaspari and O'Leary (1988) documented cooperative breeding in the form of nonparental attendance (that is, potentially unrelated adults and juveniles providing food to and brooding young). 
Between-year site fidelity to previous breeding areas in Grasshopper Sparrows varies geographically and seems to be lowest in the most densely populated portions of the species' range in the Great Plains (Soha and others, 2009; Vickery, 2020). In Montana, return rates of Grasshopper Sparrows during a 7 -year study were 8.9 percent of 45 color-banded adult males and 0 percent of 138 color-banded nestlings (Jones and others, 2007). In Nebraska, Kaspari and O’Leary (1988) banded 85 adult and juvenile Grasshopper Sparrows over a 3-year period; none were recaptured in subsequent years. Klimkiewicz and Futcher (1987) reported that a Grasshopper Sparrow banded as an immature bird in Nebraska was recaptured 3 years later at the site where it was banded.

Between-year site fidelity may be higher in less densely populated portions of the species' range. In Arizona, 38 adult males (39.2 percent) exhibited breeding site fidelity in at least 1 subsequent year, whereas 13 of the 38 were resighted in 2 subsequent years (Ruth, 2017). Additionally, several males exhibited year-round site fidelity, with five males recaptured in at least one subsequent winter on the same site; three of these five also were resighted during the subsequent breeding season, and one was recaptured in two subsequent winters and breeding seasons on the same site. In Ohio, the return rate of color-banded Grasshopper Sparrows over a 7-year period was 19 percent of 324 individuals (Ingold and others, 2010). In New York, the average annual return rate for 57 adults was 28 percent for a 3 -year banding period; 28.9 percent of 45 adult males and 33.3 percent of 12 adult females returned to their former breeding areas (Balent and Norment, 2003). The return rate for 48 first-year adults that were banded as nestlings was 2 percent (Balent and Norment, 2003). In Maryland, Skipper (1998) banded 11 adult males, 4 adult females, and 22 hatch-year juveniles over a 4-year period; two adult males were recaptured in the same breeding area in the year following banding, and three other banded males were observed singing from territories but were not recaptured. In another Maryland study, Gill and others (2006) marked 1,985 Grasshopper Sparrows over a 7-year period; annual return rates were among the highest reported for this species and other grassland birds and included 57 percent for adult males, 41 percent for adult females, and 12 percent for hatch-year individuals. In a nonmigratory population in Florida, 52 percent of 48 color-banded males were resighted or recaptured, including 21 males who occupied the same breeding territories during 2-4 successive breeding seasons (Delany and others, 1995).

Williams (2016) and Williams and Boyle (2018) captured and color-banded 647 adult male and 132 adult female Grasshopper Sparrows and examined within-year breeding dispersal and turnover of Grasshopper Sparrows in the Flint Hills of Kansas. Of 779 marked adults, 34 percent exhibited dispersal movements (Williams, 2016). Among the 647 territorial males, 33 percent defended second territories $100 \mathrm{~m}$ or more from the territory on which they were initially detected (Williams and Boyle, 2018). Dispersal distances varied from $101 \mathrm{~m}$ (the authors' minimum value) to $8,940 \mathrm{~m}$ (mean $=695 \mathrm{~m}$ ). Over the duration of the 3-year study, turnover rates of territorial males on the study plots were very high, exceeding 50 percent, with monthly turnover rates estimated at 75 percent. Williams (2016) documented that five females dispersed 144-1,321 m between nests.

\section{Species' Response to Management}

The use of burning as a treatment option for the management of Grasshopper Sparrows is more prevalent within grassland ecosystems than within shrubsteppe ecosystems, where burns typically are the result of wildfires. In southcentral Washington, Earnst and others (2009) examined the response of Grasshopper Sparrows to wildfires in bunchgrass grasslands and shrubsteppe; the researchers examined Grasshopper Sparrow abundance 4 years before and 7 years after a summer wildfire. Grasshopper Sparrow abundance was decreasing significantly before the wildfire and stabilized after the fire at a mean abundance that was lower postburn than preburn (Earnst and others, 2009). In southeastern Arizona, Bock and Bock (1992) examined Grasshopper Sparrow response to a July wildfire; Grasshopper Sparrows avoided the burned native grasslands for 2 years, probably because of reduced shrub cover. In a wildfire that occurred in Montana shrubsteppe, Grasshopper Sparrows preferred unburned over burned areas, and Grasshopper Sparrow densities were depressed for $>3$ years postburn (Bock and Bock, 1987).

Within grassland ecosystems, typical management involves burning or a combination of burning and grazing. Research that evaluates Grasshopper Sparrow response to burning-only management is summarized below, followed by research on the combination of burning and grazing. Further research into the impact of burning-only management on Grasshopper Sparrows may be warranted, as published results vary widely, ranging from periodic burning being beneficial (Madden and others, 1999) to neutral (Grant and others, 2010) and from Grasshopper Sparrow densities decreasing immediately after a burn (Volkert, 1992) to nest densities being highest immediately after a burn (Byers and others, 2017). In a combination of restored and native grasslands in eastcentral North Dakota historically subjected to various burning and grazing treatments, Johnson (1997) examined the effect of prescribed burns on Grasshopper Sparrow density over a 14-year period. Prescribed burns occurred in either spring or fall. Grasshopper Sparrow density was low within the first year postburn, then increased to about 5 years postburn, declining gradually thereafter. Within mixed-grass prairies in Lostwood National Wildlife Refuge in northwestern North Dakota, Madden (1996) applied knowledge of the refuge's fire history to evaluate the effect of burning on Grasshopper Sparrow abundance. Grasshopper Sparrow abundance was highest 1-3 years postburn; no Grasshopper Sparrows were observed in mixed-grass prairies that had not been burned for $>80$ years (Madden, 1996). Grasshopper Sparrow abundance was highest in grasslands that had been burned four times in 
the previous 15 years compared to unburned areas and areas burned 1-2 times in the previous 15 years (Madden and others, 1999). In mixed-grass prairies in J. Clark Salyer National Wildlife Refuge in north-central North Dakota, Grant and others (2010) determined that periodic prescribed fires did not affect Grasshopper Sparrow breeding abundance. In South Dakota mixed-grass prairies, densities of Grasshopper Sparrows decreased immediately after burning, presumably because of loss of nesting cover (litter and live vegetation) or loss of a food source but increased 2-3 years postburn (Forde and others, 1984). In mixed-grass and tallgrass prairies managed by the U.S. Fish and Wildlife Service in Montana, North Dakota, South Dakota, and Minnesota, there was a linear increase in Grasshopper Sparrow densities in the growing seasons after a burning-only management treatment; Grasshopper Sparrow densities were higher in mixed-grass prairie units than in tallgrass units during the second growing season after a burning-only treatment (Igl and others, 2018).

In Minnesota tallgrass prairies, Johnson and Temple (1990) found lower rates of nest depredation in recently burned prairie fragments (burned $<3$ years prior) than in fragments that had not been burned for 4 or more years. In a burned tallgrass prairie in Wisconsin, Grasshopper Sparrow abundance decreased immediately after a growing-season burn (Volkert, 1992). In CRP fields in southern Wisconsin, Byers and others (2017) reported that Grasshopper Sparrow nest densities were highest in the breeding season immediately following a spring burn and declined as time since burn increased to 3 years postburn, the duration of the study; nest densities were best explained by site-level plant species richness and were highest on sites with short, somewhat sparse vegetation. Daily nest survival rates were not affected by year since burn (Byers and others, 2017). In restored tallgrass prairies in Iowa, Grasshopper Sparrows showed no differences in abundance among restored prairies that had been burned 1 year or 2 years earlier and those that were not burned (Van Dyke and others, 2007). In Iowa pastures, nest predation by snakes was lower in burned areas. Predation by mammals and brood parasitism by Brown-headed Cowbirds were unaffected by time since fire, whereas predation by snakes was affected by time since fire. Snake predation increased in the absence of fire and was eleven times more likely in patches that were last burned 2 years earlier compared to recently burned patches (Lyons and others, 2015). In Illinois tallgrass prairies, Grasshopper Sparrows were significantly more abundant 1-2 years after a spring burn than 3 years postburn (Herkert, 1994a). In Missouri tallgrass prairies, Grasshopper Sparrow densities were not affected by spring burns (Winter, 1998; Swengel and Swengel, 2001), but densities were reduced at sites that were both hayed and burned (Swengel and Swengel, 2001). Within the Kansas Flint Hills, Robel and others (1998) found that Grasshopper Sparrow abundance was higher on spring-burned than on unburned native CRP fields, but the differences in abundance were nonsignificant. In the Flint Hills of Kansas and Oklahoma, Rahmig and others (2009) reported that Grasshopper Sparrow density was significantly lower within burned and unburned CRP fields than within burned and unburned native pastures and hayfields. Also in the Flint Hills of Kansas and Oklahoma, With and others (2008) reported that Grasshopper Sparrows did not occupy burned CRP fields and had lower occupancy within unburned CRP fields than within native pastures or hayfields.

In the Texas Panhandle, two large wildfires burned shortgrass and mixed-grass prairie pastures (grazing effects were not evaluated, nor were details on grazing intensity or duration provided) during one spring (Roberts and others, 2012, 2017). In mixed-grass prairies, Grasshopper Sparrow densities were significantly higher in unburned than in burned prairies during the second year postburn but showed no differences in the third year postburn; in shortgrass prairies, no differences in Grasshopper Sparrow densities were detected between unburned prairies and prairies burned 2-3 years previously (the burn 1 year previously was not included in analysis) (Roberts and others, 2012). Within the same grasslands, Grasshopper Sparrow nest success was higher in the second year postburn than the third year postburn, regardless of whether sites were burned or unburned (Roberts and others, 2017). Forbs, woody vegetation, and bare ground were higher around nests in the second year postburn than in the third year postburn, but litter cover was higher in the third year postburn.

In Maryland, Gill and others (2006) evaluated Grasshopper Sparrow occupancy in CRP grasslands. Grasshopper Sparrows colonized newly created CRP grasslands but were not present if the grasslands were left unburned for 2-3 years. Once burned, Grasshopper Sparrows recolonized the recently burned fields (Gill and others, 2006).

A combination of burning and grazing of rangelands is a common management practice implemented by public land managers, such as those on Federal wildlife refuges, and by private livestock producers throughout the Great Plains (Rohrbaugh and others, 1999; Danley and others, 2004). However, differences in grazing systems, seasonality of burns, and timing and intensity of livestock grazing make comparisons among studies on the effect of a combination of burning and grazing on Grasshopper Sparrow abundance difficult. In mixed-grass prairies in Saskatchewan, Richardson (2012) examined the interaction between burning and grazing on Grasshopper Sparrow abundance 1-5 years postburn. Burned conditions were created by a July wildfire, whereas grazing conditions were derived from season-long (late May to mid-September) cattle grazing at low-to-moderate $(0.43$ animal unit month [AUM] per ha with 50 percent removal of biomass) grazing intensity (Richardson and others, 2014). At 1 year postburn, Grasshopper Sparrows were not present on any combination of the burned/unburned or grazed/ungrazed conditions; by 2 years postburn, the species occurred in low numbers on the unburned and grazed pastures and ungrazed pastures (Richardson, 2012). Grasshopper Sparrows did not occupy the burned/grazed pastures until the fifth year postburn. Highest abundances during the 5-year study occurred on the unburned and ungrazed sites (Richardson, 2012). 
In mixed-grass prairies on Federal wildlife refuges in northwestern North Dakota, Danley and others (2004) compared the occurrence of singing male Grasshopper Sparrows in burned-only plots (prescribed burning schedules on plots varied from 3 to 6 burns that occurred 1-8 years since last burn; burns were conducted either in late spring or in summer [Madden and others, 1999]) to plots both burned and rotationally grazed (each of three cells per plot were grazed for 14 days from late May through mid-August; two of three cells were grazed at 0.6-1.2 AUMs per ha for a second 14-day period after a 28 -day rest; grazing occurred $1-4$ years after the last of the prescribed burns). Grasshopper Sparrow occurrence was similar in burned-only and in burned-and-grazed plots. In mixed-grass prairies in South Dakota, unburned pastures were lightly grazed ( 0.2 AUM per ha) in the dormant season by American bison (Bison bison) and burned pastures were rested from grazing during the year before a spring burn; Grasshopper Sparrows occurred in unburned pastures significantly more than in burned pastures during the breeding season (Huber and Steuter, 1984). In mixed-grass and tallgrass prairies managed by the U.S. Fish and Wildlife Service in Montana, North Dakota, South Dakota, and Minnesota, Grasshopper Sparrow densities were, on average, higher in mixed-grass units that were burned-only, grazed-only, and burned-grazed than in mixed-grass units that were rested $>5$ years (Igl and others, 2018).

In a 3-year study in shortgrass steppe in Colorado, Augustine and Derner (2015) compared the effect of a traditional season-long grazing system to a patch-burn grazing (or pyric herbivory) system on Grasshopper Sparrow abundance. Patch-burn grazing is a system in which fire is applied in spatially discrete patches in 3-4 year intervals under typical average stocking rates. Patch-burn management was applied under a fall-burning regime and moderate livestock stocking rates ( 0.6 AUM per ha) from May 15 to October 1, the same stocking rate and duration applied to the traditionally grazed pastures. Grasshopper Sparrows were not present in 1- and 2 -year-old burns, were present in unburned portions of patchburn pastures and in unburned controls, and occurred in small numbers in 3- and 4-year-old burns. Grasshopper Sparrows were five times more abundant in unburned controls in 1 year compared to 2 other years, presumably because of high precipitation the previous year (Augustine and Derner, 2015).

In western Minnesota and northwestern Iowa, Ahlering and others (2019) examined the effect of management history (time since fire or grazing), grassland type (remnant prairie or restored grassland), and land ownership (public or private ownership) on Grasshopper Sparrow abundance after habitat and landscape variables had been considered. Fire and grazing history best explained additional variation in the abundance of Grasshopper Sparrows. Grasshopper Sparrows were more abundant on grazed sites that had not been burned for over 3 years, in grasslands grazed during the survey year but not during the previous 2 years, and on private than on public lands. In State- and privately owned rangelands in the Grand River Grasslands of southern Iowa and northern Missouri, Pillsbury (2010), Pillsbury and others (2011), and Duchardt and others (2016) evaluated the response of Grasshopper Sparrows to management treatments of patch-burn grazing (that is, spatially discrete spring fires and free access by cattle at 1.7-3.1 AUMs per ha from May 1 to October 1), grazed-and-burned (that is, free access by cattle and a single complete burn), and burned-only (that is, single complete burn with no cattle). Grasshopper Sparrow densities were highest on patch-burn-grazed pastures and lowest on burned-only pastures, the latter of which likely enhanced the growth of dense vegetation avoided by Grasshopper Sparrows (Pillsbury and others, 2011; Duchardt and others, 2016). In other studies occurring within and near the Grand River Grasslands, Hovick and others (2012) examined the response of Grasshopper Sparrows nest survival and clutch size to patch-burn grazing (that is, one-third of each pasture was burned sequentially during spring such that the entire pasture was burned over the course of 3 years and grazing occurred from May to September at a rate of 3.5 to 5.9 AUMs per ha) and traditionally managed pastures (that is, burned completely in the third year of the study to prevent encroachment of woody plants and grazed under the same stocking rate as patch-burn pastures). Grasshopper Sparrow clutch sizes did not differ between treatments, but daily nest survival rates were greater in patch-burn grazed pastures than in traditionally managed pastures. Postfledging survival rates also did not differ between management treatments; the probability of a 1-day-old fledgling surviving for 1 day was 0.85 in a patch-burn grazed pasture and 0.82 in a traditionally managed pasture (Hovick and others, 2011).

The traditional combination of annual or biennial burning and grazing, sometimes referred to as intensive early-season burning in which spring burning is followed by intensive early cattle stocking, is a widespread practice in the tallgrass prairies throughout the Flint Hills of Kansas and Oklahoma, but its effects on Grasshopper Sparrows are ambiguous, with indications that the traditional practice may have no impact on abundance (for example, Zimmerman, 1993), decrease abundance (for example, Powell, 2006), harbor higher abundances than other treatments such as patch-burn grazing, reduce reproductive success relative to patch-burn grazing but still provide a source habitat (for example, Davis and others, 2016a), or create high turnover of male territories (for example, Williams and Boyle, 2018). With and others (2008) concluded that, overall, Grasshopper Sparrow populations in the Flint Hills are declining and the population is not viable.

At the Konza Prairie Biological Station in northeastern Kansas, Grasshopper Sparrow abundance was not affected by burning in moist years but was reduced after burning in drought years (Zimmerman, 1992); relative abundances did not differ between annually burned and unburned grasslands (Zimmerman, 1993). Zimmerman (1997) detected no differences in the mean number of young per attempted nest 
between areas that were burn-only and areas that were neither burned nor grazed. Drawing upon the same historical dataset as Zimmerman (1992, 1993), but with additional years of data and in contrast to those studies, Powell (2006) examined the effect of American bison grazing and prescribed burns at various intervals since the last burn; Grasshopper Sparrow abundance decreased in the season of a burn and increased with bison grazing. Bison were stocked at low intensity of 5 ha per animal, with the expected consumption of 25 percent of above-ground plant growth. In the same study area, Powell (2008) also examined the effect of cattle grazing and prescribed burns. Grasshopper Sparrow abundance was higher 1-3 years after the last burn than during the year of the burn, and in areas grazed by cattle. Cattle were grazed at low intensity of 3 ha per cow-calf pairs, with the expected consumption of about 25 percent of above-ground plant growth. Grasshopper Sparrow abundance was lower at sites burned every 4 years than those burned annually or at a 2-year frequency. Powell (2006) provided several reasons for the discrepancies between the Zimmerman (1992, 1993, 1997) studies and those of Powell (2006), including that Zimmerman pooled species abundances and that there was a confounding factor of soil moisture. At Konza Prairie and the adjacent Rannells Flint Hills Prairie Preserve, Williams and Boyle (2018, 2019) examined the effect of management treatments on Grasshopper Sparrow density and within-season dispersal within watersheds. Management treatments included pastures that were (1) intensively early stocked (annual burning and double stocking of cattle from April to July); (2) patch-burn (each patch burned completely every 3 years) with cattle grazing; (3) grazed year-long by bison and spring-burned annually or every 2 years; and (4) ungrazed. Consistently among 3 years, the number of Grasshopper Sparrow territories was highest on the intensively early stocked pastures, followed by the patchburn pastures, the bison-grazed pastures, and the ungrazed pastures (Williams and Boyle, 2018). Grasshopper Sparrow densities were highest during the early (April 30 to June 6) and late-season (July 29 to August 3) periods. In 1 of 2 years, daily nest survival was similar among grazing treatments; in the second year, daily nest survival was lower in bison-grazed pastures compared to cattle-grazed and ungrazed pastures (Williams and Boyle, 2019). Within-season breeding dispersal was estimated at 33-75 percent, with over one-third of banded males moving $>100 \mathrm{~m}$ from their original territories. Over one-half of territories changed ownership each month. Thus, although densities on plots remained fairly constant over the season, identity of individual regularly changed, indicating that habitat quality was poor (Williams and Boyle, 2018).

Within The Nature Conservancy's Tallgrass Prairie Preserve in the Flint Hills of northeastern Oklahoma, several researchers have studied the response of Grasshopper Sparrows to the combination of burning and grazing. Fuhlendorf and others (2006) concluded that Grasshopper Sparrow abundance was highest in grazed pastures that were burned annually (traditionally managed pastures) than in patch-burn grazed pastures that were burned at various intervals (that is, $0-12,13-24,25-36$, and $>36$ months earlier), and that abundance in pastures burned 13-36 months earlier were higher than pastures burned 0-12 months or $>36$ months earlier. Coppedge and others (2008) found that Grasshopper Sparrows were more abundant in traditional pastures burned once annually in the spring than in pastures burned in a patchmosaic pattern (that is, portions of the pasture were burned on a 3-year fire-return interval). Hovick and others (2015) examined avian response to interacting fire and grazing on seven landscapes with varying levels of patchiness ranging from annually burned with spring-only fires to a 4-year fire-return interval with spring and summer fires. Grasshopper Sparrows showed a nonsignificant increase in abundance in response to increases in the fire-return interval (varying from annual to a 4-year fire-return interval) and showed a significant increase in abundance with grassland heterogeneity, defined as the variation in vegetation components that generally increased with an increase in number of experimental grassland patches in the landscape. Patten and others (2006) found that Grasshopper Sparrows preferred nesting in prairies that were burned in spring and then grazed (that is, intensive early stocking, under which cattle are introduced in April following a burn and grazed for about 100 days) and in prairies that were grazed and not burned but did not prefer undisturbed prairies or roadsides. However, cowbird densities and parasitism rate of Grasshopper Sparrow nests were highest in burned pastures. Rohrbaugh and others (1999) reported that the number of Grasshopper Sparrow nests, clutch size, number of young fledged from successful nests, and nest success did not differ significantly between disturbed plots (that is, grazed or grazed and burned under the traditional spring burns and high-intensity stocking) and undisturbed plots (that is, no fire or grazing). Davis and others (2016a) concluded that fecundity (that is, the number of female young produced per female in a season) overall was similar between traditionally managed and patch-burn pastures, but when individual patch-burn years were examined, fecundity was highest within the 2-year postburn patches than in the traditionally managed pastures. Grasshopper Sparrows laid more eggs in traditional pastures but produced more young per successful nest in patch-burn pastures. In terms of maintaining population sizes, both treatments provided stable or source habitats. For patch-burn pastures specifically, the 1-year postburn and 2-year postburn patches could exceed levels necessary for maintaining a stable population of Grasshopper Sparrows under realistic adult and juvenile survival rates (Davis and others, 2016a). In northeastern Oklahoma, Grasshopper Sparrows were common in tallgrass prairie pastures regardless of burning regime: spring or fall burns conducted within the past year as well as in prairies burned within the past 2 years and $>2$ years (Londe and others, 2019).

Within the larger area encompassed by the Flint Hills of Kansas and Oklahoma, Rahmig and others (2009) and With and others (2008) reported that Grasshopper Sparrows occurred at the highest frequencies in grazed pastures, 
especially those that were intensely grazed or burned, and occurred at the lowest frequencies in CRP grasslands that had been burned or were idle. Rahmig and others (2009) found that Grasshopper Sparrow densities were lowest in burned and unburned CRP grasslands and highest in burned and unburned native hayland, burned and unburned season-long grazed pastures (one head of cattle per 1.6 ha for 180 days, mid-April through mid-October), and burned intensive-early season grazed pastures (one head of cattle per 0.8 ha for 90 days, mid-April through mid-July). Grasshopper Sparrow nesting success was lowest in pastures and highest in burned hayland. With and others (2008) predicted declines of 16-27 percent per year for Grasshopper Sparrows in the Flint Hills. In the Flint Hills of northeastern Kansas, Klute (1994) and Klute and others (1997) reported that Grasshopper Sparrows were more abundant in annually spring-burned tallgrass prairies that were moderately grazed (2.7 ha per cow-calf pair from July to December, or 1.6 ha per steer from May to October), than in annually burned seeded-native CRP grasslands, possibly because invertebrate prey populations were higher in the grazed areas. In the Flint Hills of east-central Kansas, Erickson (2009) examined season-long, intensive early stocking and patch-burn grazing systems and concluded that Grasshopper Sparrow density was similar among systems, with densities ranging from 1.29 birds per ha on patch-burn pastures grazed 1 year since fire, 1.27 birds per ha on seasonlong pastures, 1.15 birds per ha on intensive-early pastures, to 1.09 birds per ha on patch-burn pastures grazed 2 years since fire; Grasshopper Sparrows occurred on unburned patches within patch-burned pastures.

Located outside of the Flint Hills ecoregion but still within tallgrass prairies in central Kansas, Grasshopper Sparrow abundance was higher in grazed (moderately stocked with cattle from May 1 to October 31 at a rate of 160 kilograms [kg] per ha or double-stocked from May 1 to July 30) and hayed (cut once annually in July) fields than in springburned and unburned idle grasslands (Powell and Busby, 2013). In an Oklahoma study in sand sagebrush grasslands, Grasshopper Sparrow abundance was three times higher in traditional pastures (that is, summer-long grazing at 24.7 animal unit days per ha and no burning) than in patch-burn pastures (Doxon, 2009; Holcomb and others, 2014). Grasshopper Sparrow density increased as time-since-burn increased; densities were similar in unburned grasslands as in traditional pastures (Doxon, 2009).

Grasshopper Sparrow response to grazing in the absence of burning varies among studies, which likely reflects that several factors affect vegetation structure beyond grazing pressure, such as previous- and current-year precipitation and temperature (Niemuth and others, 2017), soil productivity (that is, the vegetation production potential of rangeland based on soil type and ecological-site information) (Lipsey and Naugle, 2017; Davis and others, 2020), history of land use (Bakker and others, 2002; Sliwinski and others, 2019), and topography (Renfrew and Ribic, 2002; Fischer and others, 2020). Grazing-specific factors that may impact
Grasshopper Sparrow response are the type of grazing system, the stocking rate, and the species of grazing animal (Griebel and others, 1998; Sliwinski and others, 2019; Vold and others, 2019). Land ownership (that is, public versus private) also may affect Grasshopper Sparrow response to management treatments, such as grazing (Guttery and others, 2017; Ahlering and others, 2019; Sliwinski and others, 2019). In general, Grasshopper Sparrows tolerate some degree of grazing in desert grasslands (Ruth, 2008), prefer lightly to moderately grazed pastures in mixed-grass prairies (Kantrud and Kologiski,1982; Salo and others, 2004; Sliwinski, 2011; Fischer and others, 2020), and use moderately to heavily grazed pastures in tallgrass prairies (Ahlering and Merkord, 2016). The type of grazing system (for example, season-long continuous, deferred rotation, and fixed rotation) may not affect Grasshopper Sparrow abundance (Temple and others, 1999; Sliwinski and others, 2019; Vold and others, 2019).

Most grazing-only studies that have examined the effect of grazing on Grasshopper Sparrow abundance or productivity have occurred in the Great Plains, although some studies have occurred in the bunchgrass prairies of the Northwest and the desert grasslands of the Southwest. Johnson and others (2011) reported that nest densities in Oregon bunchgrass prairies decreased with increased cattle stocking rates (varying from 0 to 43.2 AUMs), and Grasshopper Sparrow nests were not found in the pastures with the highest stocking rate. Within grassland ecosystems, typical management for Grasshopper Sparrows involves grazing-only or a combination of burning and grazing, whereas burning in combination with grazing is uncommon in shrubsteppe and desert ecosystems. In southeastern Arizona, Bock and others (1984) compared Grasshopper Sparrow abundance between semidesert grassland pastures at a single site that was ungrazed for nearly 20 years to pastures at another ranch that were grazed at an intensity estimated at one cow per 10 ha (high-density, short duration, rotational grazing); Grasshopper Sparrow abundance was significantly higher on ungrazed pastures, preferring the denser and taller grasses, and did not occur on grazed pastures (Bock and Webb, 1984; Ruth, 2015). In a study examining Grasshopper Sparrow use of desert grasslands in different valleys of Arizona, Ruth $(2008,2015)$ reported more complex results in that the densities of singing male Grasshopper Sparrows were highest in the grazed grasslands of the San Rafael Valley and exhibited sequentially lower densities in the Sonoita Valley (mostly grazed, but one ungrazed site), the grazed Animas Valley, ungrazed locations in the Altar Valley, and grazed grasslands in the San Pedro, Sulphur Springs, and San Bernardino valleys (Ruth, 2008).

In a series of phased studies conducted in the mixedgrass prairies of the Grasslands National Park in southwestern Saskatchewan, the effects of cattle grazing on abundance were examined (Sliwinski, 2011; Fischer and others, 2020). Depending on the particular study question, at various times between 2006 and 2012, avian abundance and vegetation were measured for 2 years before the reintroduction of cattle, for 4 years after cattle were grazed at stocking rates varying from 
0.25 AUM per ha to 0.83 AUM per ha, and for 3 years after cattle were removed from pastures. Pasture units contained upland and lowland portions in which upland areas were dominated by perennial graminoids and lowland areas were characterized by having more shrubs and taller forbs than upland areas. Sliwinski (2011) and Fischer and others (2020) further included ungrazed control pastures to implement a beforeafter control-impact study design. Sliwinski (2011) reported that Grasshopper Sparrow abundance increased slightly at moderate stocking rates and began to decline at 0.4 AUM per ha, declining by about 0.5 bird per plot as grazing intensity increased. Fischer and others (2020) reported that Grasshopper Sparrows exhibited high variability in the response to livestock grazing. On upland sites, Grasshopper Sparrow abundance was too low for analysis. On lowland sites, Grasshopper Sparrow abundance was highest after 2 years of rest from grazing, surpassing levels recorded during the pregrazing years, after 4 years of grazing, and the 1 year of rest. However, abundance measured 2 years after rest consistently decreased as stocking rate increased. During the grazing years, Grasshopper Sparrow abundance was highest at moderate stocking rates, peaking at about 0.4 AUM per ha. Abundance was very low before grazing and during the 1 year of rest from grazing. In Alberta mixed-grass prairies, Prescott and Wagner (1996) reported Grasshopper Sparrows were present in tame pastures of crested wheatgrass that were grazed from late April to midJune and absent from native pastures that were continuously grazed, grazed in early summer, or grazed after July 15 .

In mixed-grass prairies in northeastern Montana, livestock stocking rates were experimentally manipulated from spring through fall to achieve stocking rates of 0.73 AUM per ha to represent a high stocking rate and 0.33 AUM per ha to represent a low stocking rate (Lipsey and Naugle, 2017). Grasshopper Sparrows preferred denser-than-average cover based on an herbaceous-cover index, and abundance was not affected by the amount of biomass removed by grazing livestock (Lipsey, 2015; Lipsey and Naugle, 2017). The authors cautioned that an evaluation of cattle use without consideration of precipitation amount and soil productivity was a poor predictor of herbaceous cover. Grasshopper Sparrow abundance was affected by the interaction of cattle use and soil productivity in rangelands: high levels of use by cattle on high-productivity rangeland decreased the abundance of Grasshopper Sparrows. Cattle avoided using low-productivity grasslands, which had little potential as suitable Grasshopper Sparrow habitat at any level of cattle use (Lipsey, 2015; Lipsey and Naugle, 2017). Grasshopper Sparrow abundance also was affected by the interaction between cattle use of rangeland and precipitation: cattle reduced herbaceous cover only when precipitation in preceding years was low $(<50$ millimeters [mm]; considered a "dry" scenario), which reduced Grasshopper Sparrow abundance. In wetter conditions $(>800 \mathrm{~mm})$, the measured range of cattle use had little effect on herbaceous cover, and heavier cattle use under wet conditions was predicted to have no effect on Grasshopper Sparrow abundance (Lipsey and Naugle, 2017).
In northeastern Montana and west-central North Dakota, Vold and others (2019) examined the effect of three grazing systems on Grasshopper Sparrow abundance. Within the three-pasture, rest-rotation grazing system, cattle were turned out on a pasture in late May, moved to a second pasture in mid-August, and removed for the season after 8-10 weeks; the third pasture was rested from grazing. Within the twopasture, summer-rotation system, cattle were first turned out to pasture in early June, moved to the second pasture after 6-8 weeks, and removed in early to mid-November. Seasonlong grazing allowed cattle to graze continuously from May or early June through October or mid-November. Average stocking rates were 2.82 AUMs per ha for the three-pasture, rest-rotation system; 1.98 AUMs per ha for the summerrotation system; and 1.24 AUMs per ha for the season-long system (Vold and others, 2019). Grasshopper Sparrow abundance was highest in season-long grazing systems and was positively associated with rangeland production potential in season-long grazing systems; abundance exhibited a quadratic relationship in summer-rotation and rest-rotation grazing systems, where predictions indicated that abundance was maximized at intermediate values of rangeland production from 1,700 to 2,000 $\mathrm{kg}$ per ha. Abundance decreased with increased stocking rate among all three grazing systems (Vold and others, 2019).

In northwestern and central North Dakota, Schneider (1998) examined the effect of two grazing systems on Grasshopper Sparrow abundance. Within the twice-over deferred rotational grazing system, pastures were divided into cells through which cattle were rotated twice during the typical June-October grazing season (although some pastures received cattle in May and still contained cattle in November). Season-long grazing allowed cattle to graze continuously from May through early November. Schneider (1998) reported no difference in Grasshopper Sparrow abundance between rotational twice-over and season-long grazing systems. In mixed-grass prairies in south-central North Dakota, Salo and others (2004) reported highest densities of Grasshopper Sparrows in lightly to moderately grazed prairies (defined as 65 percent and 50 percent of forage produced in an average year remaining, respectively), intermediate sparrow densities in heavily grazed prairies (35 percent of forage remained), and lowest sparrow densities in extremely grazed prairies ( 20 percent of forage remained). In the same study area, Messmer (1990) compared Grasshopper Sparrow abundance in idle mixed-grass prairies to three grazing systems of short-duration pastures (that is, pastures rotated through a grazing schedule of about 1 week grazed and 1 month ungrazed), twice-over rotation pastures (that is, pastures grazed twice per season, with about a 2-month rest between grazing), and season-long pastures (that is, pastures grazed continuously). Messmer (1990) found no difference in Grasshopper Sparrow density among grazing systems. Grasshopper Sparrows preferred grazed over idle mixed-grass prairies and preferred silty range sites over other soil communities such as shallow-to-gravel and reseeded sites. In the northern Great 
Plains, Kantrud and Kologiski (1982) found higher Grasshopper Sparrow densities on lightly grazed (grazing intensity varied by soil type) mixed-grass prairies - specifically, typic ustoll sites - than on heavily grazed prairies; moderately grazed prairies supported intermediate sparrow densities. In grasslands managed by the U.S. Fish and Wildlife Service in Montana, North Dakota, South Dakota, and Minnesota, Grasshopper Sparrow densities were higher on mixed-grass prairies that were grazed-only than on mixed-grass prairies that were burned-only; Grasshopper Sparrow densities were higher in tallgrass prairies that were grazed-only than in tallgrass prairies that were burned-only or rested for $>5$ years (Igl and others, 2018).

In the Nebraska Sandhills, Kempema (2007) examined the effect of grazing system duration on Grasshopper Sparrow densities during a time of drought conditions. Grasshopper Sparrow densities, number of nests, and proportion of successful nests were highest on the medium-duration grazing system and lowest on the long-duration system. The average value during the growing season (May 1 to September 30) for short duration was a rotation of 3 days of grazing at 1.4 AUMs per ha; medium duration was 23 days at $1.3 \mathrm{AUMs}$ per ha, and long duration was 78 days at 1.4 AUMs per ha. Within the same area of the Nebraska Sandhills, Sliwinski and others $(2019,2020)$ examined the relationship between five grazing systems (season-long continuous, deferred rotation, management intensive, dormant season only, fixed rotation) and avian diversity during a period of above-average precipitation. Grasshopper Sparrows were among the five most common bird species within the study area. Sliwinski and others $(2019,2020)$ reported that grazing system did not affect avian community structure more than the management unit (that is, the individual ranch), and this finding was probably not related to grazing management but rather was related to landscape features (such as, distance to wetlands, forests, or shrubs). Variation in abundance of Grasshopper Sparrows was best explained by land ownership (public versus private) rather than grazing system, stocking rate, or soil types; Grasshopper Sparrow abundance was higher on publicly owned land than on privately owned land (Sliwinski and others, 2019). In wet meadows and mesic grasslands in Nebraska, Grasshopper Sparrow densities were similar between grazed and ungrazed plots, regardless of moisture conditions (Kim and others, 2008).

In shortgrass prairies in north-central Colorado, Grasshopper Sparrows were found on prairies that were heavily grazed in the previous winter (grazing intensity was defined by values of specific vegetation variables) but were not found on prairies that were heavily grazed in summer (Wiens, 1970). In the same general area, Davis and others (2020) examined the effect of two grazing systems - a traditional system of season-long grazing and a system of rest-rotation grazing - on Grasshopper Sparrow density. Grazing systems had stocking rates ranging from 0.61 to 0.70 AUM per ha, but the rest-rotational system also incorporated periods when grazing was not applied and periods when grazing was intensively applied. The potential effect of underlying ecological site (that is, a distinctive soil and plant community represented by loamy plains, sandy plains, or salt flats) also was investigated. For Grasshopper Sparrows, year and ecological site affected density more than grazing management; Grasshopper Sparrows were more abundant in the salt flats and sandy plains ecological sites than in the loamy plains ecological sites. Davis and others (2020) described grazing as having a neutral effect in the sandy and salt flats ecological sites and resting pastures from grazing benefitting the species in the subsequent year in the loamy plains ecological site. In the sandy plains and salt flats ecological sites, Grasshopper Sparrow density ranged from decreasing by 0.022 bird per ha to increasing by 0.164 bird per ha on average in rested pastures compared to traditionally grazed pastures, respectively. In the loamy plains ecological site, Grasshopper Sparrow density increased by an average of 0.415 and 0.361 bird per ha in rested pastures compared to traditionally grazed pastures, respectively (Davis and others, 2020).

Little information exists on the effects of grazing-only management techniques on Grasshopper Sparrows in midwestern and eastern grasslands. In tame pastures in southwestern Wisconsin, Grasshopper Sparrows were more abundant in continuously grazed pastures (grazed throughout the summer at levels of 2.5-4 animals per ha) than in rotationally grazed pastures (grazed for 1-2 days with 40-60 animals per ha and then left undisturbed for 10-15 days) or in ungrazed pastures (neither mowed nor grazed from May 15 to July 1) (Temple and others, 1999). In Kentucky grasslands, Sutter and Ritchison (2005) reported that grazing was less desirable to Grasshopper Sparrows than idled grasslands. The authors examined the difference in nest success between grazed grasslands (220 cattle year-round and 1,785 cattle from March 1 to October 30 on 2,102 ha) and ungrazed grasslands (mowed once per year from mid-July through August). Grasshopper Sparrow nest success and clutch size and invertebrate biomass were higher in ungrazed grasslands than on grazed grasslands; ungrazed grasslands had deeper litter depth, fewer shrubs, and taller, denser vegetation.

Livestock type may not affect Grasshopper Sparrow abundance (Griebel and others, 1998; Lueders and others, 2006; Sliwinski, 2011), but the presence of prairie dogs may (Mack, 2017; Geaumont and others, 2019). In Saskatchewan, Sliwinski (2011) examined the effect of cattle and American bison grazing on the abundance of Grasshopper Sparrows, at stocking rates varying from 0.23 to 0.83 AUM per ha. In cattle-grazed pastures, the species' abundance remained stable in pastures stocked at low-to-moderate grazing intensities. However, when cattle stocking rates exceeded 0.4 AUM per ha, Grasshopper Sparrow abundance decreased. In bison-grazed pastures, Grasshopper Sparrow abundance decreased linearly as grazing intensity increased. In mixedgrass prairies on National Grasslands in southwestern North Dakota, Grasshopper Sparrow densities did not differ between cattle-grazed pastures (0.74-1.76 AUMs per ha) and bisongrazed (0.28-0.31 AUM per ha) pastures that also had been 
managed by fire (Lueders and others, 2006). Cattle-grazed pastures had lower vegetation structure and habitat heterogeneity, whereas bison-grazed pastures had a higher vegetation structure and higher habitat heterogeneity. In that same study, Grasshopper Sparrow density did not change with distance from cattle water developments, despite increases in vegetation height-density and litter depth and decreases in coverage of cow dung and vegetation structural variability associated with reduced grazing pressure farther from the water developments (Fontaine and others, 2004). In tallgrass prairies in north-central Nebraska, Griebel and others (1998) reported that Grasshopper Sparrow abundance did not differ between cattle-grazed areas (grazing from May 15 to November 15 at about 1 AUM per ha) and bison-grazed pastures (year-round grazing at about 1.2 AUMs per hectare) that also were burned (80 percent dormant-season burns and 20 percent growingseason burns). In shortgrass prairies in northern Colorado, Wilkins and others (2019) evaluated the effect of bison reintroduction at 0.05 AUM per ha on Grasshopper Sparrow densities. The authors reported that densities increased on bison pastures after reintroduction as measured 2 years after bison reintroduction; however, densities also increased in cattle-grazed reference sites. In North Dakota mixed-grass pastures stocked with steers from early June to early October, Grasshopper Sparrows exhibited gradually decreasing densities as black-tailed prairie dog occupancy increased from 0 to 40 percent (AUM equivalents of 1.0-1.6 ha per AUM), with densities four times lower in transitional pastures (that is, pastures in which black-tailed prairie dog occupancy was reduced because of an unplanned reduction by poisoning 4.2 ha per AUM) than in pastures with no prairie dogs (Mack, 2017; Geaumont and others, 2019).

In the northern Great Plains, haying may occur within government-managed programs such as PCP and CRP (McMaster and Davis, 2001; Igl and Johnson, 2016). Periodic haying among years of planted grasslands may provide the sparser and shorter vegetation preferred by Grasshopper Sparrows. In Alberta, Manitoba, and Saskatchewan, Grasshopper Sparrows were less common in mowed PCP grasslands than in grazed PCP grasslands (McMaster and Davis, 2001). In North Dakota CRP grasslands seeded to cool-season grasses, there was no difference in abundance of Grasshopper Sparrows in the year after haying between idled and hayed portions of fields; however, Grasshopper Sparrows were found only in hayed portions in five of six CRP fields (Horn and Koford, 2000). Igl and Johnson (2016) assessed the effects of haying on abundance of grassland breeding birds in $483 \mathrm{CRP}$ grasslands in nine counties in four States in the northern Great Plains between 1993 and 2008. Grasshopper Sparrow densities in CRP fields that were idle for 5 or more years did not differ from densities in CRP grasslands that had been hayed 1, 2, 3, or 4 years earlier.

Some CRP fields are planted to switchgrass as a biomass fuel to provide a domestic energy source and wildlife habitat; switchgrass fields differ from the more traditional hayfields in that the former are typically harvested after the avian breeding season (Murray and Best, 2003). In Iowa switchgrass CRP fields, Murray and Best (2003) evaluated Grasshopper Sparrow abundance and nest success among fields that were completely mowed, fields in which 60 percent was mowed in strips with alternate unmowed strips, and fields that were completely unmowed. Harvesting occurred between November and March; switchgrass was cut to a height of $9 \mathrm{~cm}$ with a disc mower, baled, and removed from the field. Grasshopper Sparrow abundance was significantly higher in the total-harvested fields than in strip-harvested or nonharvested fields. Within strip-harvested fields, Grasshopper Sparrows preferred mowed strips to unmowed strips. Twice as many nests were found in total-harvested fields than strip-harvested fields, and no nests were found in nonharvested fields. Daily survival rate within total-harvested fields was 0.965 , and mean nest survival rate for the entire nesting cycle was 48 percent; comparable statistics were not determined for strip-harvested fields because of low numbers of nests (Murray and Best, 2003). In Wisconsin, Roth and others (2005) compared Grasshopper Sparrow abundance among five August-harvested switchgrass fields and five nonharvested fields over 2 years. The species was detected on one nonharvested field in 1 year and detected on harvested fields in both years, but in only one field before mowing in 1 year and in four fields postmowing in the second year. Grasshopper Sparrows preferred low vegetation height-density (Roth and others, 2005).

Traditional hayland management that involves an early initial cutting date and one or more subsequent harvests within a growing season may be detrimental to nesting Grasshopper Sparrows; however, the effects of haying depend on the timing and frequency of the disturbance. Using North American BBS data from Minnesota, Wisconsin, and Michigan, Corace and others (2009) examined the relationship between Grasshopper Sparrow population response and values from an index of mowing intensity that incorporated the date of first harvest, number of harvests, and weeks between harvests. The authors reported that Grasshopper Sparrows have moderate affinity for hayfields but found no relationship between mowing intensity and population trends for Grasshopper Sparrows; however, the loss of pasturehayland at a county level was positively related to declining abundance of Grasshopper Sparrows. In Iowa alfalfa fields, Grasshopper Sparrow density was highest before mowing, peaking at 80 male territories per 100 ha in early May and declining to five male territories per 100 ha by the end of May (Frawley, 1989; Frawley and Best, 1991). Average mowing date for the first alfalfa crop on the study plots occurred on June 7. Grasshopper Sparrow densities increased for the first 3 weeks after mowing but began to decrease when alfalfa was about $30 \mathrm{~cm}$ tall. Mowing caused some male Grasshopper Sparrows to vacate territories in some fields, but in other fields, males colonized the second alfalfa crop where previously no males had been present (Frawley and Best, 1991). In Iowa, where sections of CRP fields were spot-mowed for weed-control purposes, Patterson and Best (1996) also noted 
that Grasshopper Sparrows quickly colonized newly mowed areas within the fields. In Iowa hayfields of either tameseason or native-season grass species, McMullen and Harms (2020) reported no difference in the number of detections of Grasshopper Sparrows in hayfields mowed during the nesting season (mid-July) and hayfields mowed after the nesting season (mid-August), with evidence of second nesting in mowed fields. In Illinois, Grasshopper Sparrows were twice as abundant on grasslands mowed before May 1 than on unmowed areas (Herkert, 1991). In an alfalfa field in Michigan, Grasshopper Sparrows continued nesting following mowing in late June but left the study area after the second mowing in early August (Harrison, 1974). In Michigan, Grasshopper Sparrows abandoned hayfields after mowing in early July (George, 1952). In Massachusetts, the species typically abandoned hayfields after mowing, and its nests usually were destroyed by mowing operations (Forbush, 1929). In contrast, Smith (1963, 1968) found that Grasshopper Sparrows did not abandon a hayfield in Pennsylvania after mowing.

In Iowa, Van Dyke and others (2004) examined the effect of burning and mowing during spring on Grasshopper Sparrow densities in small (3-10 ha) grassland fragments restored to tallgrass species; densities were highest on mowed sites, followed by untreated and burned sites. In Nebraska CRP grasslands seeded to native tallgrass species, a stable Grasshopper Sparrow population occurred in a field that was mowed in spring 3 out of 4 years (Delisle and Savidge, 1997). In Ohio, Ingold (2002) and Ingold and others (2010) did not detect any differences in Grasshopper Sparrow annual return rates and nest densities between mowed and unmowed portions of reclaimed strip-mine grasslands.

Hayland management in past harvest seasons may impact Grasshopper Sparrow use of grasslands in the current management year. In Iowa rowcrop fields, Grasshopper Sparrows nested in grassed waterways that were mowed the previous year (Bryan and Best, 1991, 1994). In Wisconsin and Iowa CRP grasslands planted to switchgrass, Grasshopper Sparrows were more abundant in fall- and winter-harvested plots than in unharvested plots (Murray and Best, 2003; Roth and others, 2005). In Missouri tallgrass prairie fragments, Grasshopper Sparrow densities increased 1 year after haying but decreased in areas that had been hayed $>1$ year earlier (Winter, 1998). In New York, Grasshopper Sparrows preferred older hayfields ( $>10$ years since the last seeding) (Bollinger and Gavin, 1992; Bollinger, 1995). Fields mowed at earlier dates (late May-early June) the previous year had lower Grasshopper Sparrow densities than those mowed at later dates (Bollinger, 1995). Seigel and Lockwood (2010) modeled the impact of enrollment in delayed-mowing programs in New Jersey on Grasshopper Sparrow populations; the authors found that the probability of metapopulation extinction was reduced to $<10$ percent if 55-60 percent of the hayland in the study area was enrolled in the delayed-mowing program. Allen and others (2019) evaluated the effect of leaving unmowed portions of hayfields on Grasshopper Sparrow density. Grasshopper Sparrow use of unharvested portions of hayfields increased after mowing. Greater length-to-width ratios in unmowed portions were associated with higher relative densities of Grasshopper Sparrows. In fields that were completely mowed, with no unmowed portions, Grasshopper Sparrow density dropped an average of 83 percent (Allen and others, 2019). Across six eastern States, Allen and others (2021) evaluated the change in population trend for Grasshopper Sparrows relative to area and management of agricultural grasslands (that is, hay, pasture, and idle fields). The population growth rate of Grasshopper Sparrows declined about 4 percent per megagram increase in hay yield (perhaps an indication of more frequent harvests) and about 2 percent per 10-day delay in harvest.

Grasshopper Sparrows commonly occupy planted grasslands, such as CRP grasslands, during the breeding season. In Minnesota and North Dakota, abundance of Grasshopper Sparrows was higher in CRP grasslands than in Waterfowl Production Area grasslands (Koford, 1999). In North Dakota, South Dakota, Minnesota, and Montana, Grasshopper Sparrows were one of the most common breeding birds observed in several hundred CRP grasslands (Johnson and Schwartz, 1993a, 1993b; Johnson and Igl, 1995; Igl, 2009; Igl and Johnson, 2016). Within the Prairie Pothole Region, Shaffer and others (2019c) modeled the effect on the availability of suitable Grasshopper Sparrow breeding habitat of incremental losses of 10-100 percent of CRP grasslands enrolled in the Government program at 2014 levels. Estimates of suitablehabitat loss ranged from $<1$ percent (representing 107,450 ha) under a scenario of a 10 percent loss of CRP grasslands to 9 percent (representing 1 million ha) under a 100 percent loss of CRP grasslands. Shaffer and others (2019c) estimated that about 19 percent of the suitable Grasshopper Sparrow breeding habitat available in the Prairie Pothole Region in 2014 was degraded (declined in habitat quality) because of increased crop production. In six Midwest and Great Plains States, Grasshopper Sparrow abundance was substantially lower in cropland than in CRP grasslands (Best and others, 1997). In North Dakota, Johnson and Igl (1995) reported that Grasshopper Sparrow densities in CRP grasslands were higher than those in cropland and estimated that Grasshopper Sparrows would decline by over 20 percent if CRP grasslands in the State reverted to cropland. In Nebraska, Negus and others (2010) reported that Grasshopper Sparrow abundance in CRP fields managed with disking and interseeding of legumes was similar to that in idle CRP fields in the first year of the study, but Grasshopper Sparrow abundance was significantly higher in idle fields in the second year of the study. In another Nebraska study, Uden (2012) and Uden and others (2015) evaluated four scenarios of land-use change that might affect the abundance of Grasshopper Sparrows and other grassland birds. The first scenario was a baseline condition in which some rowcrops were converted to switchgrass under current conditions of climate, irrigation limitations, commodity prices, ethanol demand, and continuation of the CRP. The second scenario converted more rowcrops to switchgrass. The third scenario converted all CRP fields to switchgrass, 
and the fourth scenario converted all CRP fields to rowcrops. Grasshopper Sparrow abundance increased 19-55 percent under the first two scenarios and decreased $<2$ percent under scenarios three and four, indicating that replacing rowcrops with switchgrass was more beneficial to Grasshopper Sparrows than replacing CRP fields with switchgrass or rowcrops (Uden, 2012; Uden and others, 2015).

In Illinois, Osborne and Sparling (2013) found no difference in Grasshopper Sparrow densities in fescue-dominated CRP fields that were idle and those that were either disked in the fall, sprayed with glyphosate in the fall, or sprayed with glyphosate in the fall and interseeded with legumes in the spring. In Missouri CRP grasslands, McCoy and others (1999) reported that fecundity of Grasshopper Sparrows over a 3-year period was high enough to maintain a stable population. In Kansas, Missouri, and Nebraska, Grasshopper Sparrow abundance was positively related to percentage of landscape planted to CRP practices dominated by grasses and was negatively related to patch density of tame CRP planted within 4 years, indicating a potential preference for clumped arrangements of CRP habitat (Riffell and others, 2010). Sensitivity analysis indicated that a 10 percent increase in CRP area planted to grasses was associated with a 3.3 percent increase in Grasshopper Sparrow abundance; a 10 percent increase in patch density of new tame CRP grasslands was associated with a 2.5 percent decline in Grasshopper Sparrow abundance. In a region-wide study examining the importance of the CRP on grassland birds, Grasshopper Sparrow abundance was positively related to CRP area in four of the seven ecological regions considered (Riffell and others, 2008).

In northwestern Oklahoma, Coppedge and others (2001) evaluated population trends for Grasshopper Sparrows on three BBS routes over a 30 -year period relative to patterns of landscape change wrought by eastern redcedar encroachment into grasslands and conversion of cropland to CRP grasslands planted to Old World bluestems (Bothriochloa spp.) or lovegrasses (Eragrostis spp.). The population trend for Grasshopper Sparrow increased on the route in which the most severe redcedar encroachment was offset by increased area of CRP lands in a landscape that had the least amount of intact native grasslands within $0.4 \mathrm{~km}$ of BBS stops, indicating that Grasshopper Sparrow use of CRP fields might be related to the matrix of land uses in the surrounding landscape.

Grasshopper Sparrows also use other planted grasslands, such as restored prairies and reclaimed surface mines, during the breeding season. In South Dakota, restoration of former corn and soybean fields to tallgrass prairie was beneficial to Grasshopper Sparrows (Blankespoor, 1980). By the second growing season postrestoration, Grasshopper Sparrow was the most common species. A 2-year drought in combination with 1 year of grazing during the third and fourth growing seasons postrestoration caused a decrease in effective plant height and in vertical and horizontal plant density; the Grasshopper Sparrow remained one of the most common species, although densities dropped after the second growing season postrestoration. In Wisconsin, Grasshopper Sparrows were one of the first nesting species to colonize a restored native tallgrass prairie (Volkert, 1992). In Iowa, Grasshopper Sparrows colonized a restored grassland, in which abundance tended to be highest the second year after restoration of former cropland to tallgrass prairie compared to abundance $1,3,4-6$, and $>6$ years postrestoration, but the differences were not statistically significant and sample sizes were small (Olechnowski and others, 2009). In eastern Nebraska and western Iowa, Grasshopper Sparrows were detected almost exclusively within conservation grasslands (that is, National Wildlife Refuges, CRP grasslands, and restored and remnant prairies) with very low detections in unmanaged marginal grasslands (that is, field borders and terraces) (Cox and others, 2014). Surface mines that have been reclaimed to grasslands provide important nesting habitat for Grasshopper Sparrows in the eastern portion of the species' range (Wray and others, 1982; Piehler, 1987; Ingold, 2002; Mattice and others, 2005; Graves and others, 2010; Stauffer and others, 2011). In Pennsylvania, daily survival rates of Grasshopper Sparrow nests were greatest early and late in the breeding season; higher nest survival late in the season may have resulted from development of tall and dense growth by Queen Anne's lace (Daucus carota) after mid-July that may have decreased detection of nests by predators (Stauffer and others, 2011).

Grasshopper Sparrows occasionally use cropland during the breeding season, but it is not a preferred habitat and may be unsuitable when actively managed (Best and others, 1990). In Alberta, Manitoba, and Saskatchewan, the species was more common in grasslands enrolled in the PCP than in cropland (McMaster and Davis, 2001). In North Dakota, Grasshopper Sparrows nested at low densities during the breeding season in conventional, minimum-tillage, and organic cropland fields (Lokemoen and Beiser, 1997). In strip-intercropped fields (that is, rowcrops, legumes, and small grains are planted in a series of adjacent, narrow strips) in northeastern Iowa, Grasshopper Sparrows were present in low numbers, but no nests were found (Stallman and Best, 1996). In central Iowa, Schulte and others (2016) examined the effect of planting strips of native perennial vegetation within rowcrops on Grasshopper Sparrow abundance. Treatments were 100 percent rowcrop (that is, the reference or control), 10 percent of area planted to native vegetation in one strip on the footslope, 10 percent in multiple strips on the contour, or 20 percent in multiple strips on the contour; previous land use before experimental manipulation was tame grassland. Grasshopper Sparrows were most abundant in the year of establishment than in the 5 years postestablishment; no differences among treatments and controls were found (Schulte and others, 2016). In southwestern Iowa, Grasshopper Sparrows nested in higher densities in corn planted into sod residue than in strip cover and did not nest in corn or soybeans planted into corn residue or in conventionally tilled fields; Grasshopper Sparrows nesting in sod residue may have been exhibiting nest-site fidelity, as the fields had been pastures or hayfields in previous years (Basore and others, 1986). Grasshopper Sparrows also nested in oat fields 
and alfalfa hayland in southwestern and south-central Iowa (Laubach, 1984; Frawley and Best, 1991). In central Iowa, the species was one of the most abundant species reported in grassed waterways within rowcrop fields (Bryan and Best, 1991, 1994).

Insecticides and herbicides may have direct effects (for example, mortality or reduced productivity) or indirect effects (for example, alterations in habitat or food resources) on Grasshopper Sparrows. Mineau and Whiteside (2013) indicated that Grasshopper Sparrows have died during pesticideimpact studies but found no evidence to suggest that Grasshopper Sparrows were experiencing regional population-level effects from applications of granular insecticides (Mineau and others, 2005). In a study of organochlorine pesticide contamination in grassland passerines, Bartuszevige and others (2002) analyzed tissues from 25 Grasshopper Sparrows; six Grasshopper Sparrows were contaminated with dichlorodiphenyldichloroethylene (DDE), one with alpha benzene hexachloride, and one with dieldrin. Of the male Grasshopper Sparrows examined, the researchers found no feminization of testes. Quinn and others (2017) examined the response of grassland birds to multiple measures of agricultural change over a 40 -year period along the 41 st parallel within Colorado, Wyoming, Nebraska, and Iowa. Within this region and time period, total land area planted to cropland increased 40 percent, biomass yield increased 100 percent, and chemical use increased 500 percent. The abundance of Grasshopper Sparrows tended to decline with increased area farmed and with chemical use but not with more intensive biomass production, although the findings were not statistically significant (Quinn and others, 2017). In Maine, territory densities of Grasshopper Sparrows decreased for 2-5 years following the application of the herbicide hexazinone at a rate of $4 \mathrm{~kg}$ per ha on lowbush blueberries (Vaccinium angustifolium); herbicide applications reduced coverage of forbs, short shrubs, and short graminoids (Vickery, 1993; Vickery and others, 1999).

Herbicides may be used to reduce woody vegetation within Grasshopper Sparrow habitats. In a Texas study examining the effects of brush suppression (that is, through disking, and spraying the herbicide $2,4,5-\mathrm{T}[(2,4,5-$ Trichlorophenoxyacetic acid)] about 12 years before the study), grassland sparrows were more abundant in the treated than untreated areas (Gruver and Guthery, 1986). Grasshopper Sparrows were included with other grassland sparrows, but the effects on individual species were not examined. In eastern New Mexico, Smythe (2006) and Smythe and Haukos (2010) examined the response of grassland birds to tebuthiuron (1-[5-tert-Butyl-1,3,4-thiadiazol-2-yl]-1,3-dimethylurea) treatments to reduce shrub components in sand shinnery oak communities. Grasshopper Sparrows were not present during the breeding season in the first year of the 2-year study, possibly because of drought conditions the preceding year; in the second year, Grasshopper Sparrows had higher densities in the tebuthiuron-treated plots than in the untreated plots. On reclaimed surface mines in Ohio, Lautenbach and others (2020) examined the effect of the removal of woody vegetation on Grasshopper Sparrows. For 4 years, herbicides were applied over two areas, followed by mechanical cutting and shredding or hand cutting. Grasshopper Sparrows occurred on both the herbicide-only and the herbicideand-shredded areas at significantly higher densities than on untreated control areas; densities were highest on the herbicide-and-shredded areas. When woody canopy cover increased from 0 to 20 percent, densities of Grasshopper Sparrow decreased 74.9 percent.

Grasshopper Sparrows are fairly intolerant of urbanization, depending on the type of infrastructure or the anthropogenic disturbance. In central California, Rao and others (2008) reported that Grasshopper Sparrow presence was positively associated with proportion of low-intensity development (defined as having considerable amounts of constructed and vegetated surfaces) within $2 \mathrm{~km}$ of 100-m variable circular plots used for bird surveys but avoided landscapes with high-intensity development (defined as having high levels of constructed surfaces but no vegetated surfaces). In Alberta, average Grasshopper Sparrow abundance did not differ significantly between roadside point counts (mean abundance 0.027 bird per point count) and off-road point counts (that is, $800 \mathrm{~m}$ from the nearest roadside count; 0.062 bird per point count) (Wellicome and others, 2014). The estimated mortality of Grasshopper Sparrows at communication towers in the United States and Canada is low $(<1$ percent of estimated population size) (Longcore and others, 2013). Bock and others (1999), Lenth and others (2006), and Haire and others (2000) evaluated Grasshopper Sparrow occupancy of grasslands within Boulder, Colorado's Open Space, a buffer area against urban sprawl along the Front Range. Grasshopper Sparrows were significantly more abundant in grassland plots that were at least $200 \mathrm{~m}$ from suburban development (that is, interior plots) than on grassland plots at the interface with suburban development (that is, edge plots), despite the two plot types being of the same grassland habitat (Bock and others, 1999). Haire and others (2000) found that Grasshopper Sparrow abundance was highest at $<5$ percent urban index, as measured by summing the percentage of urban vegetation and percentage of buildings and paved area within a landscape composed of Boulder and $1 \mathrm{~km}$ surrounding the Open Space. Lenth and others (2006) evaluated differences in avian densities between clustered and dispersed housing developments; Grasshopper Sparrow densities were significantly higher in undeveloped areas than in clustered developments or dispersed developments. In eastern Oklahoma, Engle and others (1999) evaluated the response of breeding birds to low-density urban sprawl in two study areas, a sparsely populated rural area and an area close to metropolitan Tulsa. Human density increased from 3 humans per $\mathrm{km}^{2}$ in 1902 to 7 humans per $\mathrm{km}^{2}$ in 1990 in the sparsely populated area and from 12 humans per $\mathrm{km}^{2}$ in 1902 to 44 humans per $\mathrm{km}^{2}$ in 1990 in the high human density area. Grasshopper Sparrows decreased slightly in abundance in the low human density area between 1902 and 1990, with no results provided for the high human density area (Engle and others, 1999). In 
Nebraska and Iowa, tallgrass prairies surrounded by the highest levels of urbanization had the lowest Grasshopper Sparrow densities; however, Grasshopper Sparrow occurrence was unaffected by urbanization (McLaughlin and others, 2014). Urbanization was defined as the percentage of land use occupied by lawn, roads, impervious surfaces, and buildings; high urbanization was 50.2 percent, moderate was 17.5 percent, and low was 3.7 percent. In tallgrass prairies near Chicago, Illinois, Grasshopper Sparrow densities were unaffected by a gradient of urbanization (Buxton and Benson, 2016).

Grasshopper Sparrow response to energy infrastructure varies among studies. In Saskatchewan mixed-grass pastures, abundance of Grasshopper Sparrows increased with distance from natural gas wells. In northwestern North Dakota, Grasshopper Sparrow densities were reduced within $550 \mathrm{~m}$ of single-bore and multi-bore well pads at unconventional oil-extraction sites (that is, hydraulic fracturing and horizontal drilling) (Thompson and others, 2015). The species showed no apparent avoidance of gravel roads associated with drilling activities. In mixed-grass prairies in western North Dakota, Grasshopper Sparrow densities were unrelated to densities of roads or unconventional oil wells within $1.6 \mathrm{~km}$ of study plot boundaries (Chepulis, 2016). In Oklahoma, Londe and others (2019) found no evidence that Grasshopper Sparrow abundance was affected by distance to conventional oil wells (that is, grid-powered pump jacks) in tallgrass prairies under varying burning schedules. Grasshopper Sparrows avoided major gravel roadways (that is, county roads that were wide enough $[>8 \mathrm{~m}]$ for two lanes of traffic) in current-year burns, with abundance increasing linearly up to $500 \mathrm{~m}$ from roads (Londe and others, 2019). Grasshopper Sparrows showed no response to roads in prairies 13-24 months postburn and $>24$ months postburn. Between August 1992 and June 2005, remains of 172 bird species were identified in oil pits (fluid-filled pits and tanks that store waste fluids from oil production) in the United States; remains of two Grasshopper Sparrows were recovered in oil pits in Oklahoma (Trail, 2006). Within the Prairie Pothole Region, Shaffer and others (2019c) estimated that about 16 percent of the suitable Grasshopper Sparrow breeding habitat available in the Prairie Pothole Region in 2014 was degraded (that is, declined in habitat quality) owing to increased energy development, including oil, natural gas, and wind.

Wind-energy development may negatively impact Grasshopper Sparrow distribution and abundance. Beston and others (2016) developed a prioritization system to identify avian species most likely to experience population declines in the United States from wind facilities based on the species' current conservation status and the species' expected risk from wind turbines. At a score of 4.67, the Grasshopper Sparrow was among 40 of 428 species evaluated with an average priority score of at least a four or above out of nine. Beston and others (2016) estimated that 6.48 percent of the Grasshopper Sparrow breeding population in the United States is exposed to wind facilities. Loss and others (2013) reviewed published and unpublished reports on collision mortality at monopole wind turbines (that is, with a solid tower rather than a lattice tower) in the contiguous United States; three Grasshopper Sparrow mortalities were reported at three wind facilities. Erickson and others (2014) compiled data from 116 studies on small-passerine fatalities caused by collisions with turbines at wind-energy facilities in the United States and Canada. The Grasshopper Sparrow was among the 20 most common small-passerine species that were found as a fatality during a 17-year period. Wulff and others (2016) examined diurnal flight heights of Grasshopper Sparrows and determined that the species' mean flight height was $7.9 \mathrm{~m}$, which is not within the rotor-swept zone (32-124 m) of windturbine blades. Grasshopper Sparrows may avoid wind facilities during the breeding season (Shaffer and Buhl, 2016). At three wind facilities in mixed-grass prairies in North Dakota and South Dakota, Grasshopper Sparrows exhibited delayed (2-5 years after construction) displacement within $300 \mathrm{~m}$ of wind turbines. During the immediate (1-year postconstruction) time period, Grasshopper Sparrows at two of the wind facilities exhibited reduced densities within $100 \mathrm{~m}$ of turbines compared to reference sites; although the density decreases were not statistically significant, they may have been biologically important as the changes indicated 35-40 fewer Grasshopper Sparrows per 100 ha (Shaffer and Buhl, 2016).

Schmidt and others (2013) compared bird use in native warm-season grasslands and tame cool-season airfield grasslands in Ohio. Grasshopper Sparrows were found only in the airfield grasslands, likely because of the more-favorable plant community composition in airfield grasslands and because the vegetation was shorter in these tame grasslands. Because of the species' small body size, tendency for nonflocking behavior, and other factors, Schmidt and others (2013) categorized the Grasshopper Sparrow into a very low hazard level, indicating a very low probability of being struck by an aircraft. DeVault and others (2014) examined bird use between five pairs of solar arrays and nearby airport grasslands in Arizona, Colorado, and Ohio for 1 year; Grasshopper Sparrows were observed in low densities at one solar array and at one airport grassland.

\section{Management Recommendations from the Literature}

Throughout the breeding range of the Grasshopper Sparrow, the protection and restoration of large tracts of grassland habitat that support breeding populations of Grasshopper Sparrows are important (Vos and Ribic, 2013; Uden and others, 2015; Davis and others, 2016b; Guttery and others, 2017; Herse and others, 2018, 2020). Given the Grasshopper Sparrow's area sensitivity and preference for grassland landscapes, grassland patch area and configuration are important considerations for Grasshopper Sparrow conservation (Helzer and Jelinski, 1999; Davis, 2004; Lockhart and Koper, 2018). Small amounts of grassland loss can create disproportionately large 
amounts of edge habitat (Herse and others, 2020). Maintaining small grassland patches may be challenging if the encroachment of invasive species is an issue or if treatment options such as burning are infeasible because of proximity to urban or suburban areas (McLaughlin and others, 2014). However, in urban or highly agricultural landscapes, small grassland patches may be the only habitat available (Ribic and others, 2009a; McLaughlin and others, 2014). In such situations, Bakker and others (2002) and Greer (2009) emphasized the importance of conserving remaining small grassland patches embedded within landscapes with a high proportion of grassland habitat and with little or no woodland. Van Dyke and others $(2004,2007)$ recommended managing small grassland fragments for the benefit of a few bird species, as the patches may be too small to support large numbers of birds.

The degree of area sensitivity exhibited by the Grasshopper Sparrow in some studies (Ribic and others, 2009b) indicates that considerations about how much grassland area to protect and the associated edge density may affect the value of the protected grassland to Grasshopper Sparrows. Shahan and others (2017) defined two important concepts-landscape composition and landscape configuration. Landscape composition refers to the percentage cover of a particular matrix element (for example, percentage cropland and percentage grassland), whereas landscape configuration refers to the arrangement of patches within the landscape. Prioritizing the protection of grassland parcels embedded in a landscape matrix with a high proportion of other grasslands may satisfy the Grasshopper Sparrow's apparent preference for large, contiguous grasslands (Helzer and Jelinski, 1999; Davis, 2004; Veech, 2006; Quinn and others, 2017; Shahan and others, 2017). Guttery and others (2017) suggested that the surrounding landscape matrix can include multiple grassland habitat types, including but not limited to idle grasslands, pasture, and hayland.

Ruth (2015) summarized conservation actions that include the continuation, expansion, and creation of protected landscapes and of policies and programs aimed at reversing the rangewide decline of the Grasshopper Sparrow population. In areas where fragmentation is high because of urbanization and agriculture, public lands protect imperiled habitats upon which Grasshopper Sparrows rely; examples include Hanford Reach National Monument for sagebrush steppe (Earnst and Holmes, 2012); East Bay Regional Park District for California oak woodlands (Rao and others, 2008); Las Cienegas National Conservation Area for desert grasslands (Ruth and Skagen, 2018); and the Open Space of Boulder, Colorado, for shortgrass prairie (Bock and others, 1999). Federal policies that protect grassland types on public land, such as the dry sand prairies of Wisconsin found on military installations, may be key to preserving rare habitats and eastern grasslands inhabited by Grasshopper Sparrows (Vos and Ribic, 2011, 2013; Ruth, 2015; McMullen and Harms, 2020). Privately owned lands (especially pastureland generally referred to as working lands) can provide habitat and protect native ecosystems, as over 70 percent of the United States is held in private ownership (Ciuzio and others, 2013). Guttery and others (2017) found that, of the grassland types that they studied, all four of their focal species, including Grasshopper Sparrow, were positively associated with pasturelands, and Veech (2006) found that rangeland constituted a greater proportion of the landscape for increasing Grasshopper Sparrow populations than for decreasing populations. Guttery and others (2017) stated that multiple-use management aimed at livestock production and bird conservation may present the greatest opportunity for improving grassland bird population trends if wildlife management and land conservation agencies can establish meaningful incentives for, and cooperative agreements (for example, conservation easements) with, private landowners. Conservation partnerships between Federal, State, and Tribal agencies, nongovernmental organizations, and private landowners result in programs like grassbanks. Gripne (2005) described a grassbank as a conservation tool that exchanges the value of a given amount of forage for conservation benefits. Grasshopper Sparrows benefit from grassbanks for the grassland habitat protected, the high nest-success rates on private rangeland (Kempema, 2007), and in some cases, the higher abundances on private grasslands than public lands (Ahlering and others, 2019). In addition, the ability to manipulate factors such as livestock stocking rate, grazing system, and fence density (Vold and others, 2019) that affect Grasshopper Sparrow demographics require good relationships and agreements with private landowners.

Public/private partnerships also create new grasslands, with common examples being the PCP and CRP (McMaster and Davis, 2001; Igl, 2009; Wentworth and others, 2010; Igl and Johnson, 2016). Federal landowner incentive programs can provide valuable conservation benefits to a myriad of wildlife (Seigel and Lockwood, 2010). In eastern portions of the species range, former coal mines that are eligible for reclamation may be good targets for grassland creation and preservation, as they often are large $(>2,000 \mathrm{ha})$, owned by a single entity, and are not desirable for agricultural uses (Galligan and others, 2006). Blank and others (2014) reported that newer programs to create grasslands as sources for bioenergy create more preferred habitat for Grasshopper Sparrows than corn fields. Thus, incentives to convert grasslands to corn fields would be detrimental to the species (Blank and others, 2014; Uden and others, 2015). Blank and others (2014) suggested that creating bioenergy grasslands in a landscape of other grassland parcels maximizes the benefit to Grasshopper Sparrows, but planting tall and dense grasslands that promote high biomass yield may be less beneficial to Grasshopper Sparrows than less-dense grasslands. Blank and others (2014) also suggested that the timing of biomass harvests to minimize nest loss will be an important consideration. McCoy and others (2001) and Thompson and others (2009) cautioned that recommendations about planting cool-season or warm-season grass species should be evaluated with considerations to how fields are managed and whether the fields are monocultures or of multi-species seedings. Source populations of Grasshopper Sparrows can be found in both cool-season and warm-season plantings and the value of the grasslands may depend as much 
on habitat structure and management history as plant species composition (McCoy and others, 2001). CRP fields seeded to native tallgrass prairies species should be grazed or mowed to improve breeding habitat by reducing vegetative height and increasing canopy and forb coverage and invertebrate biomass (Klute, 1994).

Applying management treatments such as burning, mowing, or grazing to portions of large areas on a rotational schedule may provide a mosaic of vegetative successional stages (Renken, 1983; Renken and Dinsmore, 1987; Herkert, 1994a; Madden, 1996; Johnson, 1997; Rohrbaugh and others, 1999; Elliott and Johnson, 2017; Igl and others, 2018). If possible, management treatments, such as mowing and burning, should occur before or following the breeding season to reduce disturbances to nests and young (Whitmore, 1981; Frawley, 1989; Rodenhouse and others, 1995). Creating habitat mosaics that contain a diversity of plant structure and varying amounts of open ground will accommodate habitat needs of both juvenile and adult Grasshopper Sparrows (Small and others, 2015). Herkert (1994a) suggested that on areas larger than 80 ha, annually treated (burned, grazed, or mowed) subunits should be larger than 30 ha, or about 20-30 percent of the total area. Where small, isolated areas occur as part of a larger mosaic, a variety of successional stages should be maintained (Renken, 1983; Renken and Dinsmore, 1987; Herkert, 1994a; Madden, 1996; Johnson, 1997). Less than 50-60 percent of small, isolated prairie fragments should be treated (burned, grazed, or mowed) at any one time (Herkert, 1994a). Winter (1998) suggested burning no more than 20-30 percent of tallgrass prairie fragments annually in a rotational manner. Population responses to burning should be monitored, especially during unusually dry years, and treatment schedules should be adjusted during droughts as burning may reduce above-ground biomass productivity to levels that are undesirable to Grasshopper Sparrows (Zimmerman, 1992). Igl and others (2018) emphasized the importance of providing a mosaic of successional habitats across a landscape for grassland birds and underscored the need for heterogeneity in managed grasslands in a landscape, given the diversity of breeding-habitat preferences among grassland birds and the range of their responses to management.

Maintenance of existing rangelands and grasslands includes preventing the encroachment of invasive plant species and woody vegetation, as well as discouraging the planting of woody vegetation in or near grasslands (Whitmore, 1981; Bock and others, 1999; Grant and others, 2004; Cunningham and Johnson, 2006; Greer, 2009; Herse and others, 2020). However, in western shrubsteppe and desert grasslands, removal of shrubs may be detrimental to Grasshopper Sparrows because shrubs are used as song perches and as refugia from extreme heat (Bock and Bock, 1987; Ruth and others, 2020). Ruth and Skagen (2017) provided general recommendations for vegetation structure within desert grasslands that Grasshopper Sparrows may find as suitable habitat for territories (and nest sites) - densities of small shrubs (1-2 $\mathrm{m}$ ) are between 0.2 and 0.5 shrub per ha (slightly lower for nests), densities of large shrubs $(>2 \mathrm{~m})$ are between 0.2 and 0.3 shrub per ha, visual obstruction readings fall between 4 and $14 \mathrm{~cm}$ (between 5 and $12 \mathrm{~cm}$ for nest sites), vertical vegetation density is between 4.8 and 7.8 hits in $40 \mathrm{~cm}$ of a pole (between 5.0 and 7.6 hits on the pole for nest sites), and there is a sufficient proportion of native grasses $(>0.40)$ available for nest construction. Holmes and Miller (2010) explained the advantages of applying state-and-transition models to predict how various management treatments that are used to maintain shrubsteppe habitats, such as burning, may affect Grasshopper Sparrow demographics.

Within prairie ecosystems, the removal of woody vegetation within and along the periphery of grassland fragments enlarges the amount of interior grassland and discourages predators that may use woody vegetation as travel corridors (Winter, 1998; O'Leary and Nyberg, 2000; Patten and others, 2006). Burning, grazing, or mowing idle grasslands helps to eliminate woody vegetation (Skinner, 1974). Grant and others (2004) suggested that even nominal increases in woody vegetation could render grasslands inhospitable to Grasshopper Sparrows and that focusing initial grassland restoration efforts on grasslands with $<20$ percent encroachment would convey the highest conservation benefit. On reclaimed surface mines, Graves and others (2010) recommended removing woody vegetation to enhance the value of planted grasslands for Grasshopper Sparrows, as the species avoided woody vegetation and had lower daily nest survival near woody vegetation. Lautenbach and others (2020) recommended reducing woody vegetation on reclaimed areas to $\leq 10$ percent woody canopy coverage through such means as herbicides and mechanical shredding. On reclaimed surface mines, Stauffer and others (2011) noted that Grasshopper Sparrow productivity increased late in the nesting season; the authors indicated that these lateseason increases in nest survival underscore that agricultural and management activities could adversely affect productivity even when management is delayed until late in the nesting season.

Grant and others (2010) warned that burning as a management tool may be applied too infrequently in the northern Great Plains, and that the extent and frequency of prescribed burns need to increase above current levels in order to maintain and restore the ecological integrity of native prairie. Burning large grassland areas on a rotational basis, burning portions of the total grassland area each year, or burning small grassland areas periodically are all useful approaches to create a variety of successional stages (Renken, 1983; Renken and Dinsmore, 1987; Madden, 1996; Johnson, 1997). Although burning at $>10$-year intervals might increase nest density for some bird species in the short term, such a lengthy interval allows prairies to become encroached upon by invasive plant species, thus degrading prairie quality in the long term (Grant and others, 2011). Appropriate intervals between management treatments depend on grassland type, as mesic prairies regain litter more rapidly (1-3 years) than dry prairies (4-6 years), and sooner in southern than northern prairies (Swengel, 1996). In mixed-grass prairies, Grant and others (2011) urged the 
reestablishment of historic fire-return intervals of 5-10 years. Burning grasslands once every $2-4$ years will prevent encroachment of woody vegetation and remove thick litter (Madden, 1996; Johnson, 1997; Madden and others, 1999). In Minnesota, Johnson and Temple (1990) found lower rates of nest depredation on nests in recently burned $(<3$ years $)$ grasslands. In eastern grasslands, Gill and others (2006) recommended burning CRP grasslands every $2-3$ years so that CRP fields would remain suitable for Grasshopper Sparrows.

The suitability of grasslands managed with a combination of burning and grazing to Grasshopper Sparrows may depend on grassland type; for example, burning and grazing may be more tolerable in tallgrass prairies (Fuhlendorf and others, 2006) than in shortgrass and mixed-grass prairies (Augustine and Derner, 2015; Richardson, 2012). In shortgrass prairies of Colorado, patch-burn grazing management did not enhance habitat for Grasshopper Sparrows, as the taller vegetation preferred by this species in this habitat was removed (Augustine and Derner, 2015). Grasshopper Sparrows preferred unburned grasslands in shortgrass prairies. To benefit Grasshopper Sparrows, Augustine and Derner (2015) recommended alternative management strategies to patch-burn grazing, such as periodic rest from livestock grazing in areas not burned for $>3$ years. In northern mixed-grass prairies burned by wildfires, a study by Richardson (2012) indicated that the combination of burning and grazing did not provide preferred Grasshopper Sparrow habitat; Grasshopper Sparrows preferred undisturbed pastures. Richardson (2012) recommended a fire-return interval of 5 years or multiple small annual burns to create a gradient of burned patches. In Lostwood National Wildlife Refuge in western North Dakota, Danley and others (2004) reported that Grasshopper Sparrows were consistently present in grasslands with recurrent prescribed burns followed by grazing.

In tallgrass prairies from Minnesota to northern Missouri, Grasshopper Sparrows may tolerate some degree of burning but may be more tolerant of grazing (Pillsbury, 2010; Pillsbury and others, 2011; Duchardt and others, 2016; Ahlering and others, 2019). Ahlering and others (2019) found that Grasshopper Sparrows occupied grazed pastures that had not been burned for $>3$ years and suggested that habitat preferred by the species could be established by promoting grazing on public lands that currently are not being grazed. In the Grand River Grasslands of southern Iowa and northern Missouri, Grasshopper Sparrow abundance was lowest on burn-only pastures compared to patch-burn/grazed and complete burn/ grazed pastures, presumably because vegetation growth after burning created tall and dense structure not tolerated by the species (Pillsbury, 2010; Pillsbury and others, 2011; Duchardt and others, 2016). Patch-burn grazing was well-tolerated by Grasshopper Sparrows but did not produce the vegetative structural heterogeneity that provided suitable habitat for multiple avian species. Similar to Ahlering and others (2019), Pillsbury and others (2011) concluded that the stark reductions in livestock stocking rate that would have created heterogeneity would best be achieved on public lands and recreational private lands where revenues from livestock production would be of secondary importance. Building on the study by Pillsbury and others (2011), Duchardt and others (2016) adjusted stocking rates annually on the basis of residual vegetation in study pastures and found that avian diversity peaked at moderate stocking rates. Duchardt and others (2016) recommended grazing even after burning to provide the shorter, sparser vegetation that grazing conferred upon burned pastures and that was preferred by Grasshopper Sparrows. To provide suitable nesting habitat, Hovick and others (2012) suggested moderateto-heavy livestock stocking rates in either patch-burn grazing or totally burned and grazed pastures but cautioned that these stocking rates may not be suitable for other avian species.

With and others (2008) expressed concern about the viability of the Flint Hills in providing habitat for Grasshopper Sparrows, despite research indicating that the species is typically more abundant in pastures maintained with the traditional annual spring burning followed by intensive cattle grazing (for example, Williams and Boyle, 2018) than in alternative strategies such as patch-burn grazing (Coppedge and others, 2008). Heeding the warning of With and others (2008) will be a challenge for resource managers. Although the species commonly uses pastures under the traditional regime, the practice may negatively impact Grasshopper Sparrows by potentially creating unsuitable vegetation conditions for nesting (Powell, 2006) and increasing the rate of brood parasitism (Patten and others, 2006, 2011). Population responses need to be monitored, because higher abundance does not always reflect higher productivity (Patten and others, 2006; With and others, 2008; Rahmig and others, 2009). Williams and Boyle (2018) cautioned that although Grasshopper Sparrow density was consistent among years for grazing and burning management treatments, male turnover was high and thus, proximate cues used by the species to assess habitat quality may not predictably reflect true quality, leading to dispersal and high turnover.

Powell (2008) suggested that a 2-year fire-return interval might be more appropriate for Grasshopper Sparrows, although other grassland bird species might prefer a longer interval, such as 4 years. Hovick and others (2015) suggested that a 3- to 4-year fire-return interval might maximize avian diversity overall, but this interval may not specifically benefit Grasshopper Sparrows (Powell, 2008). Burning alone or grazing alone, without the combination of the two, might be more beneficial to Grasshopper Sparrows (Powell, 2008). Coppedge and others (2008) suggested that implementation of rotating disturbance patches via the patch-burn technique would not benefit Grasshopper Sparrows; the species was most common in annually burned grasslands. However, Brown-headed Cowbird abundance is significantly higher in pastures under the traditional management than under patch-burn grazing, and rates of brood parasitism are high (Patten and others, 2006). Patten and others (2006) found that rates of brood parasitism were positively related to edge, especially to road cuts and associated growth of woody vegetation, and advocated for minimizing road-building, removing trees and shrubs along roadsides, and refraining from planting them along new roads. 
Decoupling the effect of grazing from the effect of burning on parasitism rate would be challenging in the Flint Hills, but these management treatments affect parasitism less than edge (Patten and others, 2006). Contrary to Coppedge and others (2008), Davis and others (2016a) recommended patch-burn grazing to improve habitat for Grasshopper Sparrows, as Grasshopper Sparrow abundance in the 1-year postburn and 2-year postburn patches could exceed levels necessary for maintaining a stable population of Grasshopper Sparrows under realistic adult and juvenile survival rates. Davis and others (2016a) called for additional research into how grazing and fire intensity, patch-burn area, and fire pattern affect habitat structure for grassland birds.

With and others (2008) evaluated scenarios in which the current land use throughout the Flint Hills was altered, including one scenario in which the total area grazed or burned was reduced by 50 percent; Grasshopper Sparrows were predicted to decline under this scenario. Because such widespread alterations also would likely affect other factors, such as types and abundance of predators and nest-predation rates, With and others (2008) offered no recommendations on management scenarios related to burning and grazing. With and others (2008) and Rahmig and others (2009) recommended increasing hay production in the tallgrass prairies of the Flint Hills, as nest success has been found to be high in this habitat and the native warm-season grasses in the Flint Hills are mowed later (mid-July) than elsewhere in the Midwest, enabling birds to complete at least one nesting attempt (With and others, 2008). With and others (2008) further examined scenarios under which grasslands were restored under the CRP program, but both they and Rahmig and others (2009) found that Grasshopper Sparrows were uncommon in this habitat, thus indicating that increasing the CRP program in the Flint Hills may not be beneficial to the species.

Grazing and haying conferred more preferred habitat for Grasshopper Sparrows than burning in tallgrass prairies located outside of the Flint Hills as well as within sand sagebrush grasslands in eastern Oklahoma (Powell and Busby, 2013; Holcomb and others, 2014). Powell and Busby (2013) reported lowest densities in idle fields, either burned or unburned, indicating that grazing and haying were necessary to maintain habitat for Grasshopper Sparrows. In sand sagebrush grasslands, grazing also may be beneficial; Doxon (2009) and Holcomb and others (2014) found that Grasshopper Sparrow abundance was three times higher in unburned grazed pastures than in patch-burn pastures and that Grasshopper Sparrow density increased as time-since-burn increased. However, Powell and Busby (2013) cautioned that occasional burning in tallgrass prairies was necessary to curtail shrub encroachment, and Holcomb and others (2014) found that species richness was higher in patch-burn grazing than unburned grazed pastures, indicating a benefit to a number of other avian species.

In eastern grasslands, Whitmore (1981) suggested that late-winter burns effectively prevented encroachment of shrubs. Burning also may be beneficial in reducing nest depredation by snakes (Lyons and others, 2015).
Little information is available on the effect of grazing on Grasshopper Sparrows in the Northwest and thus, recommendations for grazing management for this region are sparse (Ruth, 2015). Grazing studies within the Arizona desert grasslands are very localized and thus management recommendations for desert grasslands also are limited (Ruth, 2015). In sparse, arid grasslands, even light grazing or burning can be detrimental if vegetation becomes too short and open for Grasshopper Sparrow use (Bock and Webb, 1984; Bock and others, 1984, 1993; Bock and Bock, 1987). In mixed-grass prairies, light-to-moderate grazing that reduces vegetation height and density and creates patchy areas is compatible with the habitat needs of the Grasshopper Sparrow, but heavy grazing that reduces litter should be avoided (Kantrud, 1981; Kantrud and Kologiski, 1982; Messmer, 1990; Berkey and others, 1993; Salo and others, 2004; Sliwinski, 2011; Vold and others, 2019). In northern mixed-grass prairies, Salo and others (2004), Sliwinski (2011), and Vold and others (2019) suggested grazing at a range of stocking rates to benefit multiple species. Sliwinski (2011) and Fischer and others (2020) reported that Grasshopper Sparrow abundance declined above 0.4 AUM per ha in Canadian mixed-grass prairies, whereas Vold and others (2019) recommended that stocking rates higher than 2 AUMs per ha should not be applied in mixed-grass prairies in northeastern Montana and western North Dakota. In the northern mixed-grass prairies of North Dakota, Grasshopper Sparrow densities were higher in lightly to moderately grazed pastures than heavily or extremely heavily grazed pastures, and grasslands grazed at low-to-moderate rates had greater biomass reserves that benefitted the suite of grassland bird species while maintaining acceptable daily rates of gain for individual cattle (Salo and others, 2004). The suite of grassland bird species was best maintained, on average, at 2.4 AUMs per ha, whereas livestock production and economic benefits to operators were best achieved on average at stocking rates from 2.4 to 4.2 AUMs per ha, adjusted for annual precipitation and soil moisture reserves. In the Nebraska Sandhills, Grasshopper Sparrows were most abundant on pastures grazed at 1.3 AUMs per ha (Kempema, 2007). Kempema (2007) stressed that maintaining the health and resilience of the Sandhills grasslands might best be achieved by managing on a landscape scale that incorporates multiple ranches and grazing systems so that a matrix of habitat structures can support multiple grassland bird species.

Managing stocking rates to achieve optimal grazing intensity for Grasshopper Sparrows likely depends on contextspecific (that is, local) factors, including grassland type, interannual variability in precipitation levels, topoedaphic conditions, range and soil productivity potential, and landscape composition (Kempema, 2007; Lipsey and Naugle, 2017; Vold and others, 2019). Lipsey and Naugle (2017) suggested that land managers evaluate current cover conditions and manage for the cover that is most limiting for birds at the time of evaluation. For example, during a summer with above-average precipitation, Grasshopper Sparrows would be less likely to be affected by grazing intensity, but grazing may 
need to be intensified in some locations to maintain suitable grassland habitat for avian species that prefer short vegetation (Lipsey and Naugle 2017). In such a situation, Fischer and others (2020) indicated that vegetation effects of livestock grazing at high stocking rates are reversible upon cessation of grazing, such that high stocking rates may be tolerated by avian species on a limited basis. During drought conditions, Kempema (2007) suggested that medium- and long-duration grazing systems may be better at maintaining avian richness than short-duration grazing systems, especially for Grasshopper Sparrows. Lipsey and Naugle (2017) suggested that grasslands with productive soils were better candidates for targeting grazing-management strategies than low-productivity grasslands (for example, shrubland), in which the same suite of species would dominate regardless of grazing intensity. This sentiment was echoed by Vold and others (2019), who also suggested that interactions between livestock grazing management and local rangeland production potential generally limit broad-scale livestock management recommendations for conservation of grassland birds in northern mixed-grass prairie ecosystems. Vold and others (2019) summed up their recommendations for effective management of rangelands in four points. Grassland bird conservation in the northern mixed-grass prairie requires continuous consideration of (1) species or guilds (for example, sparse grass, dense-grass) of management concern, (2) variable soil productivity at the local (for example, management unit) scale, (3) local annual precipitation before the summer grazing season and the interaction of soil productivity and precipitation at the pasture level, and (4) livestock utilization of rangeland vegetation within a specific pasture in the context of each of these variables (Vold and others, 2019).

Several studies in mixed-grass prairies suggested that rotational grazing systems may help achieve desired vegetation heterogeneity for breeding birds (Skinner, 1974; Berkey and others, 1993). In contrast, Vold and others (2019) failed to find that rest-rotation grazing improved avian abundance or diversity, relative to traditional season-long or summerrotation grazing. As with stocking rate, the effect on vegetation of abiotic factors, such as interannual variability in precipitation levels and soil type, may be as important as grazing system in governing the abundance and distribution of bird species (Kempema, 2007; Lipsey and Naugle, 2017, Vold and others, 2019). Vold and others (2019) recommended prioritizing the preservation and maintenance of contiguous grassland landscapes over concerns about the implementation of grazing systems, as rotational grazing systems seem to have limited effect on Grasshopper Sparrow abundance. Large expanses of grasslands ensure a diversity of vegetation structure and soilproductivity potential that support a multitude of avian species (Vold and others, 2019).

As with the previous studies in northern mixed-grass prairies, Sliwinski and others $(2019,2020)$ found that rotational grazing systems in the Nebraska Sandhills did not explain variation in abundance of Grasshopper Sparrows or three other species of the five total species examined. The authors cautioned that using a variety of grazing systems across a landscape may not confer the desired degree of vegetation heterogeneity desired to improve avian diversity. Rather, Sliwinski and others (2019) found that stocking rate, season of use, and management intensity may be better indicators of avian abundance, although Grasshopper Sparrows specifically did not respond to stocking rate or management intensity. Higher vegetation heterogeneity was found among pasture units than within a single unit, indicating the importance of viewing an individual pasture in the context of a landscape of other pastures and treating private-lands management as a coordinated effort among many pastures, and thus developing relationships with multiple private landowners will be important (Sliwinski and others, 2019, 2020). The application of a variety of long-term measures, such as heavy grazing, longterm rest, or patch-burn grazing, across a large landscape may be necessary to realize vegetation heterogeneity that would be beneficial to multiple species (Sliwinski and others, 2019).

In shortgrass prairies, Grasshopper Sparrow abundance may be impacted equally or more strongly by the amount of precipitation than by the grazing system (Davis and others, 2020). Davis and others (2020) demonstrated that year and ecological-site characteristics affected Grasshopper Sparrow density more than did grazing management. Similar to findings by Lipsey and Naugle (2017) and Vold and others (2019) in mixed-grass prairies, the implementation of grazing treatments in shortgrass prairies may need to be tailored to grassland type and to topoedaphic and precipitation conditions. For example, rest from grazing benefitted Grasshopper Sparrow densities only when it was applied to the least productive ecological site, whereas the species was always most abundant in salt flats and sandy plains ecological sites regardless of the grazing system (Davis and others, 2020). Thus, management objectives that fail to account for the unique soil and plantcommunity characteristics and the annual variation in climate variables of the landscape may be unsuccessful (Davis and others, 2020).

Most research on grazing in tallgrass prairies includes the practice of simultaneous burning (for example, Zimmerman, 1993; Fuhlendorf and others, 2006; Powell, 2006; Davis and others, 2016a; Williams and Boyle, 2018). In contrast to grazing in mixed-grass prairies, heavier grazing in tallgrass prairies may be beneficial to Grasshopper Sparrows (Ahlering and Merkord, 2016). In North Dakota tallgrass prairies, Ahlering and Merkord (2016) reported that Grasshopper Sparrow abundance peaked at moderate-to-high levels of grazing (3.21-3.71 AUMs per ha). In eastern grasslands, however, grazing may be detrimental; Sutter and Ritchison (2005) reported that rates of nest failure were higher for Grasshopper Sparrows in grazed areas than ungrazed areas in central Kentucky and suggested that grazing at one animal unit per hectare was too intense and removed too much vegetation for Grasshopper Sparrows to successfully nest.

Conventional mowing of hayland is generally detrimental to grassland bird species as traditional mowing dates occur within the avian breeding season when nests, eggs, and 
juvenile and adult birds can be destroyed or killed (Frawley and Best, 1991). Mowing also may cause Grasshopper Sparrows to abandon territories, although birds may colonize second crops (Frawley and Best, 1991). Davis and others (2016b) suggested that mowing after July 15 in Canadian hayfields might be appropriate, although more research on the survival and recruitment rates of young that fledge after haying would be merited. McMullen and Harms (2020) recommended delaying the mowing of Iowa hayfields until after July 31 and mowing some fields at the end of or early in the breeding season to provide the low vegetation preferred by Grasshopper Sparrows. In Canada, delaying the mowing of hayfields until mid-July or later may allow many nests to produce fledglings in years with normal breeding phenology; mowing should be delayed further if nesting is hampered by inclement spring weather or drought (Dale and others, 1997). Dale and others (1997) recommended that, when mowing cannot be delayed, large fields should be divided in half and each half should be mowed in alternate years, which will ensure some productivity in individual fields as well provide protective cover for fledglings in the unmowed half of the field. In Missouri tallgrass prairies, mowing on a 1-3-year rotation provided vegetation heights $(<30 \mathrm{~cm})$ suitable for Grasshopper Sparrows (Swengel and Swengel, 2001).

In contrast to the timing of mowing of conventional hayfields, the fall mowing of CRP switchgrass fields may be beneficial to Grasshopper Sparrows. Roth and others (2005) suggested that harvesting of switchgrass fields in August may create habitat the following year suitable to Grasshopper Sparrows. Murray and Best (2003) and Murray and others (2003) stated that total-harvested switchgrass fields would be beneficial for Grasshopper Sparrows, but a mixture of totalharvested and strip-harvested fields would provide habitat for additional avian species. To provide the shorter and sparser growth preferred by Grasshopper Sparrows, reducing or eliminating the application of fertilizer to switchgrass fields would be beneficial (Murray and Best, 2003). To increase habitat diversity in switchgrass fields to benefit multiple avian species, Uden and others (2015) urged harvesting switchgrass fields at different times and at varying heights, as well as investigating how switchgrass hybrids affect stand structure.

To benefit Grasshopper Sparrows in eastern haylands, Bollinger and Gavin (1992) and Bollinger (1995) recommended creating or maintaining hayland of relatively sparse, grass-dominated vegetation, a structure that is typical in eastern haylands as the original legume or legume/grass seeding mixtures age (longer than 8-10 years since planted). As with midwestern hayfields, delaying mowing benefits Grasshopper Sparrows, as fields mowed at earlier dates (late May-early June) the previous year had lower Grasshopper Sparrow densities than those mowed at later dates (Bollinger, 1995). Allen and others (2019) recommended leaving portions of hayfields unmowed to act as refugia that Grasshopper Sparrows can use after the remainder of the hayfield is harvested. Grasshopper Sparrows may prefer longer and narrower refugia strips, as contrasted to short and compact areas. Allen and others (2021) predicted that if agricultural landowners were provided with financial incentives to forego 0.9 megagram per ha per year of hay harvest, the Grasshopper Sparrow growth rate in eastern grasslands would stabilize. In an urbanized region of New Jersey, Seigel and Lockwood (2010) modeled the benefits of enrolling even moderate levels of hayfields into a Federal delayed-mowing management program, indicating that the Grasshopper Sparrow population can persist without protecting or managing all remaining grassland in the landscape, even when conservation funding is limited. However, maximizing the number of hayfields enrolled in a delayed-mowing program reduces the possibility that Grasshopper Sparrows will establish territories in nonenrolled hayfields that have earlier mowing dates and thus may act as ecological sinks/traps. In their modeled system, Seigel and Lockwood (2010) proposed an optimum strategy of enrolling a smaller percentage of hayfields in the delayed-mowing program while simultaneously removing nonenrolled hayfields, which function as ecological sinks/traps.

Productivity of Grasshopper Sparrows using cropland fields may be enhanced by leaving more crop residue on fields and decreasing the number of mechanical field operations through reduced-tillage cropping practices (Rodenhouse and others, 1995). In cultivated areas, no-tillage and minimum tillage practices are preferable to conventional tillage practices (Berkey and others, 1993; Rodenhouse and others, 1995; Koford and Best, 1996). Bryan and Best (1991, 1994) described a time period of late August but before mid-September for the mowing of grassed waterways in midwestern crop fields to reduce disturbances to nesting Grasshopper Sparrows. Grassed waterways may serve as refugia for Grasshopper Sparrows because nearby haylands and roadsides are mowed earlier in the season; however, mowing should not be delayed until mid-September because there would not be sufficient time for vegetation regrowth to provide adequate nesting cover in the following spring. Conversion of annually tilled croplands to grassland plantings will benefit Grasshopper Sparrows (Bakker and Higgins 2009). The predictive models developed by Uden and others (2015) indicated that the conversion of rowcrops to switchgrass provided notable increases in the abundance of Grasshopper Sparrows, especially when paired with late summer or fall harvests.

To lessen the negative effects of natural gas and oil development on Grasshopper Sparrows, Kalyn Bogard and Davis (2014) recommended timely cattle rotation, fencing off of gas wells, and allowing adequate resting periods for vegetative regrowth as possible management actions to reduce interactive effects of natural gas development, livestock grazing, and concomitant changes in vegetation structure. Kalyn Bogard and Davis (2014) further recommended that management prescriptions be based on the habitat requirements of individual species, but with the recognition that management actions tailored to enhance habitat for one species might have a deleterious effect on another species. Thompson and others (2015) stated that the footprint of oil development could be minimized by clustering oil wells along corridors and on bore pads rather 
than placing numerous single-bore well pads throughout the landscape.

To reduce negative impacts from wind turbines, Loss and others (2013) stressed the importance of considering speciesspecific and location-specific risks and making multiscale decisions about where to site wind facilities and individual wind turbines in the context of risks to individual bird species. Allison and others (2019) listed the Grasshopper Sparrow as a species of management and regulatory concern and suggested that actions may be required to mitigate the effects of displacement from wind-energy infrastructure. Shaffer and others (2019b) developed an avian-impact offset method to guide compensatory mitigation of habitat loss associated with anthropogenic developments such as wind, oil, and natural gas facilities and related road infrastructure. The avian-impact offset method calculates the biological value (measured in terms of avian density) lost when Grasshopper Sparrows and other species avoid otherwise suitable breeding habitat owing to the presence of the infrastructure. The method converts biological value to the traditional unit of measure (that is, hectares of grassland) in which land is purchased or sold, so that compensatory mitigation can be implemented in the form of conservation easements or grassland reconstruction at the local, regional, or landscape scales (Shaffer and others, 2019b). To this end, Shaffer and others (2019b) applied the models of Niemuth and others (2017) to develop a geospatial tool that identifies locations for placement of compensatory offset sites with equivalent biological value as impact sites. Additionally, the tool can be used before the construction of facilities to identify locations that would require little compensatory mitigation if developed, relative to other potential locations.

DeVault and others (2014) recommended that solar arrays be located with airfields to minimize the impacts of solar-energy development on biodiversity. Schmidt and others (2013) found that Grasshopper Sparrows were at low risk of colliding with aircraft and that airfield grasslands provided suitable habitat for the species.

To make oil production waste fluids inaccessible to Grasshopper Sparrow and other birds, Trail (2006) recommended replacing open oil pits with closed tanks or other closed containment systems. If open pits are retained, Trail (2006) recommended increased netting to exclude wildlife. To be effective, netting should be sturdy and supported by a steel frame to provide complete enclosure and should be maintained and monitored to ensure that it remains effective under all conditions.

\section{References}

Adams, H.L., Burger, L.W., Jr., and Riffell, S., 2013, Disturbance and landscape effects on avian nests in agricultural conservation buffers: The Journal of Wildlife Management, v. 77, no. 6, p. 1213-1220. [Also available at https://dx.doi. org/10.1002/jwmg.568.]
Agnew, W., Uresk, D.W., and Hansen, R.M., 1986, Flora and fauna associated with prairie dog colonies and adjacent ungrazed mixed-grass prairie in western South Dakota: Journal of Range Management, v. 39, no. 2, p. 135-139. [Also available at https://doi.org/10.2307/3899285.]

Ahlering, M.A., Johnson, D.H., and Elliott, L.H., 2019, Land ownership and use influence grassland bird abundance: The Journal of Wildlife Management, v. 83, no. 2, p. 343-355. [Also available at https://doi.org/10.1002/jwmg.21590.]

Ahlering, M.A., Johnson, D.H., and Faaborg, J., 2009, Factors associated with arrival densities of Grasshopper Sparrow (Ammodramus savannarum) and Baird's Sparrow ( $A$. bairdii) in the upper Great Plains: The Auk, v. 126, no. 4, p. 799-808. [Also available at https://doi.org/10.1525/ auk.2009.08154.]

Ahlering, M.A., and Merkord, C.L., 2016, Cattle grazing and grassland birds in the northern tallgrass prairie: The Journal of Wildlife Management, v. 80, no. 4, p. 643-654. [Also available at https://dx.doi.org/10.1002/jwmg.1049.]

Allen, M.C., Burger, J., and Lockwood, J.L., 2019, Evaluation of unharvested refugia for grassland bird conservation within active hayfields: Avian Conservation and Ecology, v. 14, no. 2, 15. [Also available at https://doi.org/10.5751/ ACE-01457-140215.]

Allen, M.C., Lockwood, J.L., and Burger, J., 2021, Finding clarity in ecological outcomes using empirical integrated social-ecological systems - A case study of agriculturedependent grassland birds: Journal of Applied Ecology, v. 58, no. 3, p. 528-538. [Also available at https://doi. org/10.1111/1365-2664.13776.]

Allison, T.D., Diffendorfer, J.E., Baerwald, E.F., Beston, J.A., Drake, D., Hale, A.M., Hein, C.D., Huso, M.M., Loss, S.R., Lovich, J.E., Strickland, M.D., Williams, K.A., and Winder, V.L., 2019, Impacts to wildlife of wind energy siting and operation in the United States: Issues in Ecology, Report No. 21, accessed March 2021 at https:/www.esa.org/wpcontent/uploads/2019/09/Issues-in-Ecology_Fall-2019.pdf.

Andersen, E.M., and Steidl, R.J., 2019, Woody plant encroachment restructures bird communities in semiarid grasslands: Biological Conservation, v. 240, article 108276. [Also available at https://doi.org/10.1016/j.biocon.2019.108276.]

Andersen, E.M., and Steidl, R.J., 2020, Plant invasions alter settlement patterns of breeding grassland birds: Ecosphere, v. 11, no. 1, article 303012. [Also available at https://doi. org/10.1002/ecs2.3012.]

Arnold, T.W., and Higgins, K.F., 1986, Effects of shrub coverages on birds of North Dakota mixed-grass prairies: Canadian Field-Naturalist, v. 100, no. 1, p. 10-14. 
Augustine, D.J., and Derner, J.D., 2015, Patch-burn grazing management, vegetation heterogeneity, and avian responses in a semi-arid grassland: The Journal of Wildlife Management, v. 79, no. 6, p. 927-936. [Also available at https://doi. org/10.1002/jwmg.909.]

Bakker, K.K., and Higgins, K.F., 2009, Planted grasslands and native sod prairie-Equivalent habitat for grassland birds?: Western North American Naturalist, v. 69 , no. 2, p. 235-242. [Also available at https://doi. org/10.3398/064.069.0212.]

Bakker, K.K., Naugle, D.E., and Higgins, K.F., 2002, Incorporating landscape attributes into models for migratory grassland bird conservation: Conservation Biology, v. 16, no. 6, p. 1638-1646. [Also available at https://doi.org/10.1046/ j.1523-1739.2002.01328.x.]

Balent, K.L., and Norment, C.J., 2003, Demographic characteristics of a Grasshopper Sparrow population in a highly fragmented landscape of western New York: Journal of Field Ornithology, v. 74, no. 4, p. 341-348. [Also available at https://doi.org/10.1648/0273-8570-74.4.341.]

Baltensperger, A.P., Dixon, M.D., and Swanson, D.L., 2020, Implications of future climate- and land-change scenarios on grassland bird abundance and diversity in the Upper Missouri River Basin: Landscape Ecology, v. 35, p. 17571773. [Also available at https://doi.org/10.1007/s10980020-01050-4.]

Bar-Massada, A., Wood, E.M., Pidgeon, A.M., and Radeloff, V.C., 2012, Complex effects of scale on the relationships of landscape pattern versus avian species richness and community structure in a woodland savanna mosaic: Ecography, v. 35, no. 5, p. 393-411. [Also available at https://doi. org/10.1111/j.1600-0587.2011.07097.x.]

Bartuszevige, A.M., Capparella, A.P., Harper, R.G., Frick, J.A., Criley, B., Doty, K., and Erhart, E., 2002, Organochlorine pesticide contamination in grassland-nesting passerines that breed in North America: Environmental Pollution, v. 117, no. 2, p. 225-232. [Also available at https://doi. org/10.1016/S0269-7491(01)00272-X.]

Basore, N.S., Best, L.B., and Wooley, J.B., 1986, Bird nesting in Iowa no-tillage and tilled cropland: The Journal of Wildlife Management, v. 50, no. 1, p. 19-28. [Also available at https://doi.org/10.2307/3801482.]

Berkey, G., Crawford, R., Galipeau, S., Johnson, D., Lambeth, D., and Kreil, R., 1993, A review of wildlife management practices in North Dakota-Effects on nongame bird populations and habitats: Denver, Colo., U.S. Fish and Wildlife Service, Report submitted to Region 6, $51 \mathrm{p}$.
Berman, G.M., 2007, Nesting success of grassland birds in fragmented and unfragmented landscapes of north central South Dakota: Brookings, S. Dak., South Dakota State University, Master's Thesis, $64 \mathrm{p}$.

Bernath-Plaisted, J.S., Panjabi, A.O., Guido, N.A., Bell, K.D., Drilling, N., Strasser, E.H., Johnson, S.K., and Correll, M.D., 2021, Quantifying multiple breeding vital rates in two declining grassland songbirds: Avian Conservation and Ecology, v. 16, no. 1, p. 19. [Also available at https://doi. org/10.5751/ACE-01875-160119.]

Berthelsen, P.S., 1989, Value of the Conservation Reserve Program to birds in the Texas southern high plains: Lubbock, Tex., Texas Tech University, Master's Thesis, 106 p.

Berthelsen, P.S., and Smith, L.M., 1995, Nongame bird nesting on CRP lands in Texas Southern High Plains: Journal of Soil and Water Conservation, v. 50, no. 6, p. 672-675. [Also available at https://www.jswconline.org/content/50/6/672. short.]

Best, L.B., Bergin, T.M., and Freemark, K.E., 2001, Influence of landscape composition on bird use of rowcrop fields: The Journal of Wildlife Management, v. 65, no. 3, p. 442-449. [Also available at https://doi.org/10.2307/3803096.]

Best, L.B., Campa, H., III, Kemp, K.E., Robel, R.J., Ryan, M.R., Savidge, J.A., Weeks, H.P., Jr., and Winterstein, S.R., 1997, Bird abundance and nesting in CRP fields and cropland in the Midwest - A regional approach: Wildlife Society Bulletin, v. 25, no. 4, p. 864-877.

Best, L.B., Whitmore, R.C., and Booth, G.M., 1990, Use of cornfields by birds during the breeding season-The importance of edge habitat: American Midland Naturalist, v. 123, no. 1, p. 84-99. [Also available at https://doi. org/10.2307/2425762.]

Beston, J.A., Diffendorfer, J.E., Loss, S.R., and Johnson, D.H., 2016, Prioritizing avian species for their risk of population level consequences from wind energy development: PLoS One, v. 11, no. 3, p. e0150813. [Also available at https://doi. org/10.1371/journal.pone.0150813.]

Bielfelt, B.J., 2013, Invasion by a native grass-Implications of increased dominance of Heteropogon contortus (tanglehead) for grassland birds: Kingsville, Tex., Texas A\&M University-Kingsville, Master's Thesis, 117 p.

Birkenholz, D.E., 1973, Habitat relationships of grassland birds at Goose Lake Prairie Nature Preserve, in Hulbert, L.C., ed., Proceedings of the third Midwest Prairie Conference: Manhattan, Kans., Kansas State University, p. 63-66. 
Blank, P.J., Sample, D.W., Williams, C.L., and Turner, M.G., 2014, Bird communities and biomass yields in potential bioenergy grasslands: PLoS One, v. 9, no. 10, p. e109989. [Also available at https://doi.org/10.1371/journal. pone.0109989.]

Blankespoor, G.W., 1980, Prairie restoration-Effects on nongame birds: The Journal of Wildlife Management, v. 44, no. 3, p. 667-672. [Also available at https://doi. org/10.2307/3808015.]

Bock, C.E., and Bock, J.H., 1987, Avian habitat occupancy following fire in a Montana shrubsteppe: Prairie Naturalist, v. 19 , no. 3 , p. 153-158.

Bock, C.E., and Bock, J.H., 1992, Response of birds to wildfire in native versus exotic Arizona grassland: The Southwestern Naturalist, v. 37, no. 1, p. 73-81. [Also available at https://doi.org/10.2307/3672149.]

Bock, C.E., Bock, J.H., and Bennett, B.C., 1999, Songbird abundance in grasslands at a suburban interface on the Colorado High Plains, in Vickery, P.D., and Herkert, J.R., eds., Ecology and conservation of grassland birds of the Western Hemisphere: Studies in Avian Biology, v. 19, p. 131-136.

Bock, C.E., Bock, J.H., Kenney, W.R., and Hawthorne, V.M., 1984, Responses of birds, rodents, and vegetation to livestock exclosure in a semidesert grassland site: Journal of Range Management, v. 37, no. 3, p. 239-242. [Also available at https://doi.org/10.2307/3899146.]

Bock, C.E., Saab, V.A., Rich, T.D., and Dobkin, D.S., 1993, Effects of livestock grazing on Neotropical migratory landbirds in western North America, in Finch, D.M., and Stangel, P.W., eds., Status and management of Neotropical migratory birds: Fort Collins, Colo., U.S. Department of Agriculture, Forest Service, Rocky Mountain Forest and Range Experiment Station, General Technical Report RM-229, p. 296-309.

Bock, C.E., and Webb, B., 1984, Birds as grazing indicator species in southeastern Arizona: The Journal of Wildlife Management, v. 48, no. 3, p. 1045-1049. [Also available at https://doi.org/10.2307/3801466.]

Bohannon, R., and Blinnikov, M., 2019, Habitat fragmentation and breeding bird populations in western North Dakota after the introduction of hydraulic fracturing: Annals of the American Association of Geographers, v. 109, no. 5, p. 1471-1492. [Also available at https://doi.org/10.1080/24 694452.2019.1570836.]

Bollinger, E.K., 1988, Breeding dispersion and reproductive success of Bobolinks in an agricultural landscape: Ithaca, N.Y., Cornell University, Ph.D. Dissertation, 189 p.
Bollinger, E.K., 1995, Successional changes and habitat selection in hayfield bird communities: The Auk, v. 112, no. 3, p. $720-730$.

Bollinger, E.K., and Gavin, T.A., 1992, Eastern Bobolink populations - Ecology and conservation in an agricultural landscape, in Hagan, J.M., III, and Johnston, D.W., eds., Ecology and conservation of Neotropical migrant landbirds: Washington, D.C., Smithsonian Institute Press, p. 497-506.

Browder, S.F., Johnson, D.H., and Ball, I.J., 2002, Assemblages of breeding birds as indicators of grassland condition: Ecological Indicators, v. 2, no. 3, p. 257-270. [Also available at https://doi.org/10.1016/S1470160X(02)00060-2.]

Bryan, G.G., and Best, L.B., 1991, Bird abundance and species richness in grassed waterways in Iowa rowcrop fields: American Midland Naturalist, v. 126, no. 1, p. 90-102. [Also available at https://doi.org/10.2307/2426153.]

Bryan, G.G., and Best, L.B., 1994, Avian nest density and success in grassed waterways in Iowa rowcrop fields: Wildlife Society Bulletin, v. 22, no. 4, p. 583-592.

Butler, C.J., 2003, The disproportionate effect of global warming on the arrival dates of short-distance migratory birds in North America: The Ibis, v. 145, no. 3, p. 484495. [Also available at https://doi.org/10.1046/j.1474919X.2003.00193.x.]

Buxton, V.L., and Benson, T.J., 2016, Conservation-priority grassland bird response to urban landcover and habitat fragmentation: Urban Ecosystems, v. 19, no. 2, p. 599-613. [Also available at https://doi.org/10.1007/s11252-016-0527-3.]

Byers, C.M., Ribic, C.A., Sample, D.W., Dadisman, J.D., and Guttery, M.R., 2017, Grassland bird productivity in warm season grass fields in southwest Wisconsin: American Midland Naturalist, v. 178, no. 1, p. 47-63. [Also available at https://doi.org/10.1674/0003-0031-178.1.47.]

Cady, S.M., O’Connell, T.J., Loss, S.R., Jaffe, N.E., and Davis, C.A., 2019, Species-specific and temporal scale-dependent responses of birds to drought: Global Change Biology, v. 25, no. 8, p. 2691-2702. [Also available at https://doi. org/10.1111/gcb.14668.]

Chapman, R.N., Engle, D.M., Masters, R.E., and Leslie, D.M., Jr., 2004, Grassland vegetation and bird communities in the southern Great Plains of North America: Agriculture, Ecosystems and Environment, v. 104, no. 3, p. 577-585. [Also available at https://doi.org/10.1016/j.agee.2004.01.026.]

Chepulis, B.J., 2016, Grassland bird response to landscapelevel and site-specific variables in the Little Missouri National Grassland: Fargo, N. Dak, North Dakota State University, Master's Thesis, 139 p. 
Ciuzio, E., Hohman, W.L., Martin, B., Smith, M.D., Stephens, S., Strong, A.M., and Vercauteren, T., 2013, Opportunities and challenges to implementing bird conservation on private lands: Wildlife Society Bulletin, v. 37, no. 2, p. 267-277. [Also available at https://doi.org/10.1002/wsb.266.]

Clark, T.W., Campbell, T.W., III, Socha, D.G., and Casey, D.E., 1982, Prairie dog colony attributes and associated vertebrate species: The Great Basin Naturalist, v. 42, no. 4, p. 572-582.

Coppedge, B.R., Engle, D.M., Masters, R.E., and Gregory, M., 2001, Avian response to landscape change in fragmented southern Great Plains grasslands: Ecological Applications, v. 11, no. 1, p. 47-59. [Also available at https:// doi.org/10.1890/1051-0761(2001)011[0047:ARTLCI]2.0 .CO;2.]

Coppedge, B.R., Engle, D.M., Masters, R.E., and Gregory, M.S., 2004, Predicting juniper encroachment and CRP effects on avian community dynamics in southern mixedgrass prairie, USA: Biological Conservation, v. 115, no. 3, p. 431-441. [Also available at https://doi.org/10.1016/ S0006-3207(03)00160-5.]

Coppedge, B.R., Fuhlendorf, S.D., Harrell, W.C., and Engle, D.M., 2008, Avian community response to vegetation and structural features in grasslands managed with fire and grazing: Biological Conservation, v. 141, no. 5, p. 1196-1203. [Also available at https://doi.org/10.1016/j. biocon.2008.02.015.]

Corace, R.G., III, Flaspohler, D.J., and Shartell, L.M., 2009, Geographical patterns in openland cover and hayfield mowing in the Upper Great Lakes region-Implications for grassland bird conservation: Landscape Ecology, v. 24, no. 3, p. 309-323. [Also available at https://doi.org/10.1007/ s10980-008-9306-8.]

Cox, A.W., Wolfenbarger, L.L., Berkeley, L.I., Engberg, S.E., Janousek, W.M., Klug, P.E., Rider, N.L., and McCarty, J.P., 2014, Grassland bird communities on conservation and marginal grasslands in an agricultural landscape: Agriculture, Ecosystems and Environment, v. 193, p. 53-59. [Also available at https://doi.org/10.1016/j.agee.2014.04.026.]

Crosby, A.D., Elmore, R.D., Leslie, D.M., Jr., and Will, R.E., 2015, Looking beyond rare species as umbrella speciesNorthern Bobwhites (Colinus virginianus) and the conservation of grassland and shrubland birds: Biological Conservation, v. 186, p. 233-240. [Also available at https://doi. org/10.1016/j.biocon.2015.03.018.]

Cunningham, M.A., and Johnson, D.H., 2006, Proximate and landscape factors influence grassland bird distributions: Ecological Applications, v. 16, no. 3, p. 10621075. [Also available at https://doi.org/10.1890/10510761(2006)016\%5B1062:PALFIG\%5D2.0.CO;2.]
Dale, B.C., Martin, P.A., and Taylor, P.S., 1997, Effects of hay management regimes on grassland songbirds in Saskatchewan: Wildlife Society Bulletin, v. 25, no. 3, p. 616-626.

Danley, R.F., Murphy, R.K., Madden, E.M., and Smith, K.A., 2004, Species diversity and habitat of grassland passerines during grazing of a prescribe-burned, mixed-grass prairie: Western North American Naturalist, v. 64, no. 1, p. 72-77.

Davis, C.A., Churchwell, R.T., Fuhlendorf, S.D., Engle, D.M., and Hovick, T.J., 2016a, Effect of pyric herbivory on source-sink dynamics in grassland birds: Journal of Applied Ecology, v. 53, no. 4, p. 1004-1012. [Also available at https://doi.org/10.1111/1365-2664.12641.]

Davis, K.P., Augustine, D.J., Monroe, A.P., Derner, J.D., and Aldridge, C.L., 2020, Adaptive rangeland management benefits grassland birds utilizing opposing vegetation structure in the shortgrass steppe: Ecological Applications, v. 30, no. 1, p. e02020. [Also available at https://doi.org/10.1002/ eap.2020.]

Davis, S.K., 2004, Area sensitivity in grassland passerinesEffects of patch size, patch shape, and vegetation structure on bird abundance and occurrence in southern Saskatchewan: The Auk, v. 121, no. 4, p. 1130-1145. [Also available at https://doi.org/10.2307/4090481.]

Davis, S.K., and Duncan, D.C., 1999, Grassland songbird occurrence in native and crested wheatgrass pastures of southern Saskatchewan, in Vickery, P.D., and Herkert, J.R., eds., Ecology and conservation of grassland birds of the Western Hemisphere: Studies in Avian Biology, v. 19, p. 211-218.

Davis, S.K., Ludlow, S.M., and McMaster, D.G., 2016b, Reproductive success of songbirds and waterfowl in native mixed-grass pasture and planted grasslands used for pasture and hay: The Condor, v. 118, no. 4, p. 815-834. [Also available at https://doi.org/10.1650/CONDOR-16-16.1.]

Davis, S.K., and Sealy, S.G., 2000, Cowbird parasitism and nest predation in fragmented grasslands of southwestern Manitoba, in Smith, J.N.M., Cook, T.L., Rothstein, S.I., Robinson, S.K., and Sealy, S.G., eds., Ecology and management of cowbirds and their hosts: Austin, Tex., University of Texas Press, p. 220-228.

DeJong, J.R., Naugle, D.E., Bakker, K.K., Quamen, F.R., and Higgins, K.F., 2004, Impacts of agricultural tillage on grassland birds in western South Dakota, in Egan, D., and Harrington, J.A., eds., Proceedings of the nineteenth North American Prairie Conference: Madison, Wis., University of Wisconsin, p. 76-80.

Delany, M.F., Clinton, T.M., and Progulske, D.R., Jr., 1995, Territory size and movements of Florida Grasshopper Sparrows: Journal of Field Ornithology, v. 66, no. 2, p. 305-309. 
Delisle, J.M., 1995, Avian use of fields enrolled in the Conservation Reserve Program in southeast Nebraska: Lincoln, Nebr., University of Nebraska, Master's Thesis, 38 p.

Delisle, J.M., and Savidge, J.A., 1996, Reproductive success of Grasshopper Sparrows in relation to edge: Prairie Naturalist, v. 28 , no. 3 , p. 107-113.

Delisle, J.M., and Savidge, J.A., 1997, Avian use and vegetation characteristics of Conservation Reserve Program fields: The Journal of Wildlife Management, v. 61, no. 2, p. 318 325. [Also available at https://doi.org/10.2307/3802587.]

DeVault, T.L., Seamans, T.W., Schmidt, J.A., Belant, J.L., Blackwell, B.F., Mooers, N., Tyson, L.A., and Van Pelt, L., 2014, Bird use of solar photovoltaic installations at US airports-Implications for aviation safety: Landscape and Urban Planning, v. 122, p. 122-128. [Also available at https://doi.org/10.1016/j.landurbplan.2013.11.017.]

Dieni, J.S., and Jones, S.L., 2003, Grassland songbird nest site selection patterns in northcentral Montana: The Wilson Bulletin, v. 115, no. 4, p. 388-396. [Also available at https:// doi.org/10.1676/03-055.]

Doxon, E.D., 2009, Nesting and feeding ecology of grassland birds in mixed-grass prairie managed with patch-burn techniques: Stillwater, Okla., Oklahoma State University, Ph.D. Dissertation, 273 p., accessed October 2020 at https:// shareok.org/bitstream/handle/11244/6845/Department $\% 20$ of $\% 20$ Natural $\% 20$ Resource $\% 20$ Ecology\%20and\%20Management_06.pdf? sequence $=1$ \&isAllowed=y.

Dreitz, V.J., Stinson, L.T., Hahn, B.A., Tack, J.D., and Lukacs, P.M., 2017, A large-scale perspective for managing prairie avifauna assemblages across the western US-Influences of habitat, land ownership and latitude: PeerJ, v. 5, p. e2879. [Also available at https://doi.org/10.7717/peerj.2879.]

Ducey, J., and Miller, L., 1980, Birds of an agricultural community: Nebraska Bird Review, v. 48, no. 3, p. 58-68.

Duchardt, C.J., Augustine, D.J., and Beck, J.L., 2019, Threshold responses of grassland and sagebrush birds to patterns of disturbance created by an ecosystem engineer: Landscape Ecology, v. 34, no. 4, p. 895-909. [Also available at http:// doi.org/10.1007/s10980-019-00813-y.]

Duchardt, C.J., Miller, J.R., Debinski, D.M., and Engle, D.M., 2016, Adapting the fire-grazing interaction to small pastures in a fragmented landscape for grassland bird conservation: Range Ecology and Management, v. 69, no. 4, p. 300-309. [Also available at https://doi.org/10.1016/j. rama.2016.03.005.]
Duchardt, C.J., Porensky, L.M., Augustine, D.J., and Beck, J.L., 2018, Disturbance shapes grassland bird communities on a grassland-sagebrush ecotone: Ecosphere, v. 9, no. 10, p. e02483. [Also available at http://doi.org/10.1002/ ecs2.2483.]

Earnst, S.L., and Holmes, A.L., 2012, Bird-habitat relationships in Interior Columbia Basin shrubsteppe: The Condor, v. 114, no. 1, p. 15-29. [Also available at https://doi. org/10.1525/cond.2012.100176.]

Earnst, S.L., Newsome, H.L., LaFramboise, W.L., and LaFramboise, N., 2009, Avian response to wildfire in Interior Columbia Basin shrubsteppe: The Condor, v. 111, no. 2, p. 370-376. [Also available at https://doi.org/10.1525/ cond.2009.080109.]

Elliott, L.H., and Johnson, D.H., 2017, Local-scale habitat associations of grassland birds in southwestern Minnesota: American Midland Naturalist, v. 178, no. 2, p. 165-188. [Also available at https://doi.org/10.1674/0003-0031178.2.165.]

Elliott, P.F., 1976, The role of community factors in cowbirdhost interactions: Manhattan, Kans., Kansas State University, Ph.D. Dissertation, 62 p.

Elliott, P.F., 1978, Cowbird parasitism in the Kansas tall grass prairie: The Auk, v. 95, no. 1, p. 161-167. [Also available at https://doi.org/10.2307/4085507.]

Engle, D.M., Griner, T.L., Boren, J.C., Masters, R.E., and Gregory, M.S., 1999, Response of breeding birds in the Great Plains to low density urban sprawl: Great Plains Research, v. 9, p. 55-73.

Erickson, A.N., 2009, Responses of grassland birds to patchburn grazing in the Flint Hills of Kansas: Manhattan, Kans., Kansas State University, Master's Thesis, 71 p.

Erickson, W.P., Wolfe, M.M., Bay, K.J., Johnson, D.H., and Gehring, J.L., 2014, A comprehensive analysis of small-passerine fatalities from collision with turbines at wind energy facilities: PLoS One, v. 9, no. 9, p. e107491. [Also available at https://doi.org/10.1371/journal.pone.0107491.]

Faanes, C.A., and Lingle, G.R., 1995, Breeding birds of the Platte River Valley of Nebraska: Jamestown, N. Dak., U.S. Geological Survey, Northern Prairie Wildlife Research Center, $412 \mathrm{p}$.

Fedy, B., Devries, J.H., Howerter, D.W., and Row, J.R., 2018, Distribution of priority grassland bird habitats in the Prairie Pothole Region of Canada: Avian Conservation and Ecology, v. 13, no. 1, article 4. [Also available at https://doi. org/10.5751/ACE-01143-130104.] 
Fischer, S, Henderson, D.C., and Koper, N., 2020, A resilient system-North American mixed-grass prairie responds to livestock exclusion: Biological Conservation, v. 243, article 108453. [Also available at https://doi.org/10.1016/j. biocon.2020.108453.]

Fletcher, R.J., Jr., and Koford, R.R., 2002, Habitat and landscape associations of breeding birds in native and restored grasslands: The Journal of Wildlife Management, v. 66 , no. 4, p. 1011-1022. [Also available at https://doi. org/10.2307/3802933.]

Fontaine, A.L., Kennedy, P.L., and Johnson, D.H., 2004, Effects of distance from cattle water developments on grassland birds: Journal of Range Management, v. 57, no. 3, p. 238-242. [Also available at https://doi. org $/ 10.2307 / 4003790$.

Forbush, E.H., 1929, Birds of Massachusetts and other New England States. Part III. Land birds from sparrows to thrushes: Boston, Mass, Massachusetts Department of Agriculture, $466 \mathrm{p}$.

Forde, J.E., Sloan, N.F., and Shown, D.A., 1984, Grassland habitat management using prescribed burning in Wind Cave National Park, South Dakota: Prairie Naturalist, v. 16, no. 3, p. $97-110$.

Frawley, B.J., 1989, The dynamics of nongame bird breeding ecology in Iowa alfalfa fields: Ames, Iowa, Iowa State University, Master's Thesis, 94 p. [Also available at https:// doi.org/10.31274/rtd-180813-13196.]

Frawley, B.J., and Best, L.B., 1991, Effects of mowing on breeding bird abundance and species composition in alfalfa fields: Wildlife Society Bulletin, v. 19, no. 2, p. 135-142.

Frey, C.M., Jensen, W.E., and With, K.A., 2008, Topographic patterns of nest placement and habitat quality for grassland birds in tallgrass prairie: American Midland Naturalist, v. 160 , no. 1 , p. 220-234. [Also available at https://doi. org/10.1674/0003-0031(2008)160\%5B220:TPONPA\%5D2 .0.CO;2.]

Fritcher, S.C., Rumble, M.A., and Flake, L.D., 2004, Grassland bird densities in seral stages of mixed-grass prairie: Journal of Range Management, v. 57, no. 4, p. 351-357. [Also available at https://doi.org/10.2307/4003858.]

Fuhlendorf, S.D., Harrell, W.C., Engle, D.M., Hamilton, R.G., Davis, C.A., and Leslie, D.M., Jr., 2006, Should heterogeneity be the basis for conservation? Grassland bird response to fire and grazing: Ecological Applications, v. 16, no. 5, p. 1706-1716. [Also available at https://doi. org/10.1890/1051-0761(2006)016\%5B1706:SHBTBF\%5D 2.0.CO;2.]
Galligan, E.W., DeVault, T.L., and Lima, S.L., 2006, Nesting success of grassland and savanna birds on reclaimed surface coal mines of the midwestern United States: The Wilson Journal of Ornithology, v. 118, no. 4, p. 537-546. [Also available at https://doi.org/10.1676/05-086.1.]

Geaumont, B.A., Hovick, T.J., Limb, R.F., Mack, W.M., Lipinski, A.R., and Sedivec, K.K., 2019, Plant and bird community dynamics in mixed-grass prairie grazed by native and domestic herbivores: Rangeland Ecology and Management, v. 72, no. 2, p. 374-384. [Also available at https://doi. org/10.1016/j.rama.2018.10.002.]

George, A.D., O'Connell, T.J., Hickman, K.R., and Leslie, D.M., 2013, Food availability in exotic grasslands-A potential mechanism for depauperate breeding assemblages: The Wilson Journal of Ornithology, v. 125, no. 3, p. 526533. [Also available at https://doi.org/10.1676/13-003.1.]

George, J.L., 1952, The birds on a southern Michigan farm: Ann Arbor, Mich., University of Michigan, Ph.D. Dissertation, $413 \mathrm{p}$.

George, T.L., Fowler, A.C., Knight, R.L., and McEwen, L.C., 1992, Impacts of a severe drought on grassland birds in western North Dakota: Ecological Applications, v. 2, no. 3, p. 275-284. [Also available at https://doi. org/10.2307/1941861.]

Gill, D.E., Blank, P., Parks, J., Guerard, J.B., Lohr, B., Schwartzman, E., Gruber, J.G., Dodge, G., Rewa, C.A., and Sears, H.F., 2006, Plants and breeding bird response on a managed Conservation Reserve Program grassland in Maryland: Wildlife Society Bulletin, v. 34, no. 4, p. 944-956. [Also available at https://doi.org/10.2193/00917648(2006)34\%5B944:PABBRO\%5D2.0.CO;2.]

Giuliano, W.M., and Daves, S.E., 2002, Avian response to warm-season grass use in pasture and hayfield management: Biological Conservation, v. 106, no. 1, p. 1-9. [Also available at https://doi.org/10.1016/S0006-3207(01)00126-4.]

Glass, A.J., Caven, A.J., Kim, D., Sutton, M.O., and Arcilla, N., 2020, Climate change and land management implications for a declining Neotropical migratory songbird breeding in the North American Great Plains: Avian Conservation and Ecology, v. 15, no. 1, p. e4. [Also available at https:// doi.org/10.5751/ACE-01515-150104.]

Gorzo, J.M., Pidgeon, A.M., Thogmartin, W.E., Allstadt, A.J., Radeloff, V.C., Heglund, P.J., and Vavrus, S.J., 2016, Using the North American Breeding Bird Survey to assess broadscale response of the continent's most imperiled avian community, grassland birds, to weather variability: The Condor, v. 118 , no. 3, p. 502-512. [Also available at https://doi. org/10.1650/CONDOR-15-180.1.] 
Grant, T.A., Madden, E., and Berkey, G.B., 2004, Tree and shrub invasion in northern mixed-grass prairie-Implications for breeding grassland birds: Wildlife Society Bulletin, v. 32, no. 3, p. 807-818. [Also available at https://doi. org/10.2193/0091-7648(2004)032[0807:TASIIN]2.0.CO;2.]

Grant, T.A., Madden, E.M., Shaffer, T.L., and Dockens, J.S., 2010, Effects of prescribed fire on vegetation and passerine birds in northern mixed-grass prairie: The Journal of Wildlife Management, v. 74, no. 8, p. 1841-1851. [Also available at https://doi.org/10.2193/2010-006.]

Grant, T.A., Shaffer, T.L., Madden, E.M., and Berkey, G.B., 2011, Ducks and passerines nesting in northern mixed-grass prairie treated with fire: Wildlife Society Bulletin, v. 35, no. 4, p. 368-376. [Also available at https://doi.org/10.1002/ wsb.65.]

Graves, B.M., Rodewald, A.D., and Hull, S.D., 2010, Influence of woody vegetation on grassland birds within reclaimed surface mines: The Wilson Journal of Ornithology, v. 122, no. 4, p. 646-654. [Also available at https://doi. org/10.1676/09-101.1.]

Greer, M.J., 2009, An evaluation of habitat use and requirements for grassland bird species of greatest conservation need in central and western South Dakota: Brookings, S. Dak., South Dakota State University, Master's Thesis, $158 \mathrm{p}$.

Greer, M.J., Bakker, K.K., and Dieter, C.D., 2016, Grassland bird response to recent loss and degradation of native prairie in central and western South Dakota: The Wilson Journal of Ornithology, v. 128, no. 2, p. 278-289. [Also available at https://doi.org/10.1676/wils-128-02-278-289.1.]

Griebel, R.L., Winter, S.L., and Steuter, A.A., 1998, Grassland birds and habitat structure in Sandhills prairie management using cattle or bison plus fire: Great Plains Research, v. 8, no. 2 , p. $255-268$.

Gripne, S.L., 2005, Grassbanks-Bartering for conservation: Rangelands, v. 27, no. 1, p. 24-38. [Also available at https:// doi.org/10.2111/1551-501X(2005)27<24:GBFC>2.0.CO;2.]

Gruver, B.J., and Guthery, F.S., 1986, Effects of brush control and game-bird management on nongame birds: Journal of Range Management, v. 39, no. 3, p. 251-253. [Also available at https://doi.org/10.2307/3899061.]

Guido, N.A., 2020, Habitat selection across the reproductive cycle of grassland songbirds in the northern Great Plains: Orono, Maine, University of Maine, Master's Thesis, 116 p.
Guttery, M.R., Ribic, C.A., Sample, D.W., Paulios, A., Trosen, C., Dadisman, J., Schneider, D., and Horton, J.A., 2017, Scale-specific habitat relationships influence patch occupancy-Defining neighborhoods to optimize the effectiveness of landscape-scale grassland bird conservation: Landscape Ecology, v. 32, no. 3, p. 515-529. [Also available at https://doi.org/10.1007/s10980-016-0462-y.]

Haire, S.L., Bock, C.E., Cade, B.S., and Bennett, B.C., 2000, The role of landscape and habitat characteristics in limiting abundance of grassland nesting songbirds in an urban open space: Landscape and Urban Planning, v. 48, no. 1-2, p. 65-82. [Also available at https://doi.org/10.1016/ S0169-2046(00)00044-X.]

Harms, T.M., Murphy, K.T., Lyu, X., Patterson, S.S., Kinkead, K.E., Dinsmore, S.J., and Frese, P.W., 2017, Using landscape habitat associations to prioritize areas of conservation action for terrestrial birds: PLoS One, v. 12, no. 3, p. e0173041. [Also available at https://doi.org/10.1371/ journal.pone.0173041.]

Harrison, K.G., 1974, Aspects of habitat selection in grassland birds: Kalamazoo, Mich., Western Michigan University, Master's Thesis, $82 \mathrm{p}$.

Helzer, C.J., 1996, The effects of wet meadow fragmentation on grassland birds: Lincoln, Nebr., University of Nebraska, Master's Thesis, $65 \mathrm{p}$.

Helzer, C.J., and Jelinski, D.E., 1999, The relative importance of patch area and perimeter-area ratio to grassland breeding birds: Ecological Applications, v. 9, no. 4, p. 1448-1458. [Also available at https://doi.org/10.2307/2641409.]

Henderson, A.E., and Davis, S.K., 2014, Rangeland health assessment-A useful tool for linking range management and grassland bird conservation?: Rangeland Ecology and Management, v. 67, no. 1, p. 88-98. [Also available at https://doi.org/10.2111/REM-D-12-00140.1.]

Herkert, J.R., 1991, An ecological study of the breeding birds of grassland habitats within Illinois: Urbana, Ill., University of Illinois, Ph.D. Dissertation, 112 p.

Herkert, J.R., 1994a, Breeding bird communities of midwestern prairie fragments-The effects of prescribed burning and habitat-area: Natural Areas Journal, v. 14, no. 2, p. $128-135$.

Herkert, J.R., 1994b, The effects of habitat fragmentation on midwestern grassland bird communities: Ecological Applications, v. 4, no. 3, p. 461-471. [Also available at https:// doi.org/10.2307/1941950.] 
Herkert, J.R., Reinking, D.L., Wiedenfeld, D.A., Winter, M., Zimmerman, J.L., Jensen, W.E., Finck, E.J., Koford, R.R., Wolfe, D.H., Sherrod, S.K., Jenkins, M.A., Faaborg, J., and Robinson, S.K., 2003, Effects of prairie fragmentation on the nest success of breeding birds in the midcontinental United States: Conservation Biology, v. 17, no. 2, p. 587594. [Also available at https://doi.org/10.1046/j.15231739.2003.01418.x.]

Herse, M.R., With, K.A., and Boyle, W.A., 2018, The importance of core habitat for a threatened species in changing landscapes: Journal of Applied Ecology, v. 55, no. 5, p. 2241-2252. [Also available at https://doi. org/10.1111/1365-2664.13234.]

Herse, M.R., With, K.A., and Boyle, W.A., 2020, Grassland fragmentation affects declining tallgrass prairie birds most where large amounts of grassland remain: Landscape Ecology, v. 35, no. 12, p. 2791-2804. [Also available at https:// doi.org/10.1007/s10980-020-01064-y.]

Herse, M.R., With, K.A., and Boyle, W.A., 2021, Correction to-Grassland fragmentation affects declining tallgrass prairie birds most where large amounts of grassland remain: Landscape Ecology, v 36, p.943-944. [Also available at https://doi.org/10.1007/s10980-020-01158-7.]

Hickman, K.R., Farley, G.H., Channell, R., and Steier, J.E., 2006, Effects of Old World bluestem (Bothriochloa ischaemum) on food availability and avian community composition within the mixed-grass prairie: The Southwestern Naturalist, v. 51, no. 4, p. 524-530. [Also available at https://doi. org/10.1894/0038-4909(2006)51[524:EOOWBB]2.0.CO;2.]

Holcomb, E.D., Davis, C.A., and Fuhlendorf, S.D., 2014, Patch-burn management-Implications for conservation of avian communities in fire-dependent sagebrush ecosystems: The Journal of Wildlife Management, v. 78, no. 5, p. 848856. [Also available at https://doi.org/10.1002/jwmg.723.]

Holmes, A.L., and Miller, R.F., 2010, State-and-transition models for assessing Grasshopper Sparrow habitat use: The Journal of Wildlife Management, v. 74, no. 8, p. 1834-1840. [Also available at https://doi.org/10.2193/2009-417.]

Horn, D.J., and Koford, R.R., 2000, Relation of grassland bird abundance to mowing of Conservation Reserve Program fields in North Dakota: Wildlife Society Bulletin, v. 28, no. 3, p. 653-659.

Hovick, T.J., Elmore, R.D., Fuhlendorf, S.D., Engle, D.M., and Hamilton, R.G., 2015, Spatial heterogeneity increases diversity and stability in grassland bird communities: Ecological Applications, v. 25, no. 3, p. 662-672. [Also available at https://doi.org/10.1890/14-1067.1.]
Hovick, T.J., Miller, J.R., Dinsmore, S.J., Engle, D.M., Debinski, D.M., and Fuhlendorf, S.D., 2012, Effects of fire and grazing on Grasshopper Sparrow nest survival: The Journal of Wildlife Management, v. 76, no. 1, p. 19-27. [Also available at https://doi.org/10.1002/jwmg.243.]

Hovick, T.J., Miller, J.R., Koford, R.R., Engle, D.M., and Debinski, D.M., 2011, Postfledging survival of Grasshopper Sparrows in grasslands managed with fire and grazing: The Condor, v. 113, no. 2, p. 429-437. [Also available at https:// doi.org/10.1525/cond.2011.100135.]

Hubbard, R.D., Althoff, D.P., Blecha, K.A., Bruvold, B.A., and Japuntich, R.D., 2006, Nest site characteristics of Eastern Meadowlarks and Grasshopper Sparrows in tallgrass prairie at the Fort Riley Military Installation, Kansas: Transactions of the Kansas Academy of Science, v. 109, no. 3-4, p. 168-174. [Also available at https://doi.org/10.1660/00228443(2006)109\%5B168:NSCOEM\%5D2.0.CO;2.]

Huber, G.E., and Steuter, A.A., 1984, Vegetation profile and grassland bird response to spring burning: Prairie Naturalist, v. 16 , no. 2 , p. 55-61.

Hull, S.D., 2002, The relationships among vegetative structure, arthropod populations, and grassland bird abundance and reproductive success on Wildlife Production Areas in Ohio: Columbus, Ohio, The Ohio State University, Ph.D. Dissertation, $100 \mathrm{p}$.

Hull, S.D., Robel, R.J., and Kemp, K.E., 1996, Summer avian abundance, invertebrate biomass, and forbs in Kansas CRP: Prairie Naturalist, v. 28, no. 1, p. 1-12.

Igl, L.D., 2009, Breeding bird use of grasslands enrolled in the Conservation Reserve Program in the northern Great Plains: Fargo, N. Dak., North Dakota State University, Ph.D. Dissertation, $199 \mathrm{p}$.

Igl, L.D., and Johnson, D.H., 2007, Brown-headed Cowbird, Molothrus ater, parasitism and abundance in the northern Great Plains: Canadian Field-Naturalist, v. 121, no. 3, p. 239-255. [Also available at https://doi.org/10.22621/cfn. v121i3.471.]

Igl, L.D., and Johnson, D.H., 2016, Effects of haying on breeding birds in CRP grasslands: The Journal of Wildlife Management, v. 80, no. 7, p. 1189-1204. [Also available at https://doi.org/10.1002/jwmg.21119.]

Igl, L.D., Johnson, D.H., and Kantrud, H.A., 2008, A historical perspective - Changes in grassland breeding bird densities within major habitats in North Dakota between 1967 and 1992-1993, in Springer, J.T., and Springer, E.C., eds., Prairie invaders - Proceedings of the twentieth North American Prairie Conference: Kearney, Nebr., University of Nebraska, p. 275-295. 
Igl, L.D., Newton, W.E., Grant, T.A., and Dixon, C.S., 2018, Adaptive management in native grasslands managed by the U.S. Fish and Wildlife Service-Implications for grassland birds: U.S. Geological Survey Open-File Report 2018-1152, 61 p. [Also available at https://doi.org/10.3133/ ofr20181152.]

Igl, L.D., Shaffer, J.A., Johnson, D.H., and Buhl, D.A., 2017, The influence of local- and landscape-level factors on wetland breeding birds in the Prairie Pothole Region of North and South Dakota: U.S. Geological Survey OpenFile Report 2017-1096, 65 p. [Also available at https://doi. org/10.3133/ofr20171096.]

Ingold, D.J., 2002, Use of a reclaimed stripmine by grassland nesting birds in east-central Ohio: Ohio Journal of Science, v. 102 , no. 3 , p. 56-62.

Ingold, D.J., Dooley, J.L., and Cavender, N., 2010, Nest-site fidelity in grassland birds on mowed versus unmowed areas on a reclaimed surface mine: Northeastern Naturalist, v. 17, no. 1, p. 125-134. [Also available at https://doi. org/10.1656/045.017.0110.]

Intergovernmental Panel on Climate Change, 2000, IPCC special report-Emissions scenarios: United Kingdom, accessed May 2020 at https://www.ipcc.ch/site/assets/ uploads/2018/03/sres-en.pdf.

Jacobs, R.B., Thompson, F.R., III, Koford, R.R., La Sorte, F.A., Woodward, H.D., and Fitzgerald, J.A., 2012, Habitat and landscape effects on abundance of Missouri's grassland birds: The Journal of Wildlife Management, v. 76, no. 2, p. 372-381. [Also available at https://doi.org/10.1002/ jwmg.264.]

Janes, S.W., 1983, Status, distribution, and habitat selection of the Grasshopper Sparrow in Morrow County, Oregon: Murrelet, v. 64 , no. 2 , p. 51-54. [Also available at https://doi. org $/ 10.2307 / 3534692$.]

Jensen, W.E., 1999, Nesting habitat and responses to habitat edges of three grassland passerine species: Emporia, Kans., Emporia State University, Master's Thesis, 58 p.

Johnson, D.H., 1997, Effects of fire on bird populations in mixed-grass prairie, in Knopf, F.L., and Samson, F.B., eds., Ecology and conservation of Great Plains vertebrates: New York, N.Y., Springer-Verlag, p. 181-206. [Also available at https://doi.org/10.1007/978-1-4757-2703-6_8.]

Johnson, D.H., and Igl, L.D., 1995, Contributions of the Conservation Reserve Program to populations of breeding birds in North Dakota: The Wilson Bulletin, v. 107, no. 4, p. 709-718.
Johnson, D.H., and Igl, L.D., 2001, Area requirements of grassland birds-A regional perspective: The Auk, v. 118, no. 1, p. 24-34. [Also available at https://doi. org/10.2307/4089756.]

Johnson, D.H., and Schwartz, M.D., 1993a, The Conservation Reserve Program and grassland birds: Conservation Biology, v. 7, no. 4, p. 934-937. [Also available at https://doi. org/10.1046/j.1523-1739.1993.740934.x.]

Johnson, D.H., and Schwartz, M.D., 1993b, The Conservation Reserve Program - Habitat for grassland birds: Great Plains Research, v. 3, no. 2, p. 273-295.

Johnson, R.G., and Temple, S.A., 1986, Assessing habitat quality for birds nesting in fragmented tallgrass prairies, in Verner, J., Morrison, M.L., and Ralph, C.J., eds., Wildlife 2000-Modeling habitat relationships of terrestrial vertebrates: Madison, Wis., University of Wisconsin Press, p. 245-249.

Johnson, R.G., and Temple, S.A., 1990, Nest predation and brood parasitism of tallgrass prairie birds: The Journal of Wildlife Management, v. 54, no. 1, p. 106-111. [Also available at https://doi.org/10.2307/3808909.]

Johnson, T.N., Kennedy, P.L., DelCurto, T., and Taylor, R.V., 2011, Bird community responses to cattle stocking rates in a Pacific Northwest bunchgrass prairie: Agriculture, Ecosystems and Environment, v. 144, no. 1, p. 338-346. [Also available at https://doi.org/10.1016/j.agee.2011.10.003.]

Jones, S.L., 2011, Territory size in mixed-grass prairie songbirds: Canadian Field-Naturalist, v. 125, no. 1, p. 12-15. [Also available at http://doi.org/10.22621/cfn.v125i1.1115.]

Jones, S.L., Dieni, J.S., and Gouse, P.J., 2010, Reproductive biology of a grassland songbird community in northcentral Montana: The Wilson Journal of Ornithology, v. 122, no. 3, p. 455-464. [Also available at https://doi.org/10.1676/08171.1.]

Jones, S.L., Dieni, J.S., Green, M.T., and Gouse, P.J., 2007, Annual return rates of breeding grassland songbirds: The Wilson Journal of Ornithology, v. 119, no. 1, p. 89-94. [Also available at https://doi.org/10.1676/05-158.1.]

Kahl, R.B., Baskett, T.S., Ellis, J.A., and Burroughs, J.N., 1985, Characteristics of summer habitats of selected nongame birds in Missouri: Columbia, Mo., University of Missouri-Columbia, Research Bulletin 1056, 155 p.

Kalyn Bogard, H.J., 2011, Natural gas development and grassland songbird abundance in southwestern Saskatchewan-The impact of gas wells and cumulative disturbance: Regina, Saskatchewan, University of Regina, Master's Thesis, $154 \mathrm{p}$. 
Kalyn Bogard, H.J., and Davis, S.K., 2014, Grassland songbirds exhibit variable responses to the proximity and density of natural gas wells: The Journal of Wildlife Management, v. 78 , no. 3, p. 471-482. [Also available at https://doi. org/10.1002/jwmg.684.]

Kantrud, H.A., 1981, Grazing intensity effects on the breeding avifauna of North Dakota native grasslands: Canadian Field-Naturalist, v. 95, no. 4, p. 404-417.

Kantrud, H.A., and Kologiski, R.L., 1982, Effects of soils and grazing on breeding birds of uncultivated upland grasslands of the northern Great Plains: Washington, D.C., U.S. Fish and Wildlife Service, Wildlife Research Report 15, 33 p.

Kaspari, M., and O'Leary, H., 1988, Nonparental attendants in a north-temperate migrant: The Auk, v. 105, no. 4, p. $792-$ 793.

Kempema, S.L.F., 2007, The influence of grazing systems on grassland bird density, productivity, and species richness on private rangeland in the Nebraska Sandhills: Lincoln, Nebr., University of Nebraska, Master's Thesis, 178 p.

Kendeigh, S.C., 1941, Birds of a prairie community: The Condor, v. 43, no. 4, p. 165-174. [Also available at https://doi. org/10.2307/1364328.]

Kim, D.H., Newton, W.E., Lingle, G.R., and Chavez-Ramirez, F., 2008, Influence of grazing and available moisture on breeding densities of grassland birds in the central Platte River Valley, Nebraska: The Wilson Journal of Ornithology, v. 120, no. 4, p. 820-829. [Also available at https://doi. org/10.1676/07-153.1.]

King, J.W., and Savidge, J.A., 1995, Effects of the Conservation Reserve Program on wildlife in southeast Nebraska: Wildlife Society Bulletin, v. 23, no. 3, p. 377-385.

Klimkiewicz, M.K., and Futcher, A.G., 1987, Longevity records of North American birds - Coerebinae through Estrildidae: Journal of Field Ornithology, v. 58, no. 3, p. 318-333.

Klute, D.S., 1994, Avian community structure, reproductive success, vegetative structure, and food availability in burned Conservation Reserve Program fields and grazed pastures in northeastern Kansas: Manhattan, Kans., Kansas State University, Master's Thesis, $168 \mathrm{p}$.

Klute, D.S., Robel, R.J., and Kemp, K.E., 1997, Will conversion of Conservation Reserve Program (CRP) lands to pasture be detrimental for grassland birds in Kansas?: American Midland Naturalist, v. 137, no. 2, p. 206-212. [Also available at https://doi.org/10.2307/2426840.]

Knapton, R.W., 1979, Birds of the Gainsborough-Lyleton region: Regina, Saskatchewan, Saskatchewan Natural History Society, Special Publication 10, $72 \mathrm{p}$.
Koford, R.R., 1999, Density and fledging success of grassland birds in Conservation Reserve Program fields in North Dakota and west-central Minnesota, in Vickery, P.D., and Herkert, J.R., eds., Ecology and conservation of grassland birds of the Western Hemisphere: Studies in Avian Biology, v. 19, p. 187-195.

Koford, R.R., and Best, L.B., 1996, Management of agricultural landscapes for the conservation of Neotropical migratory birds, in Thompson, F.R., III, ed., Management of midwestern landscapes for the conservation of Neotropical migratory birds: Detroit, Mich., U.S. Department of Agriculture, Forest Service, General Technical Report NC-187, p. $68-88$.

Langham, G.M., Schuetz, J.G., Distler, T., Soykan, C.U., and Wilsey, C., 2015, Conservation status of North American birds in the face of future climate change: PLoS One, v. 10, no. 9, p. e0135350. [Also available at https://doi. org/10.1371/journal.pone.0135350.]

Laubach, R., 1984, Breeding birds of Sheeder Prairie Preserve, west-central Iowa: Proceedings of the Iowa Academy of Science, v. 91, no. 4, p. 153-163.

Lautenbach, J.M., Stricker, N., Ervin, M., Hershner, A., Harris, R., and Smith, C., 2020, Woody vegetation removal benefits grassland birds on reclaimed surface mines: Journal of Fish and Wildlife Management, v. 11, no. 1, p. 89-98. [Also available at https://doi.org/10.3996/062019-JFWM-053.]

Lenth, B.A., Knight, R.L., and Gilgert, W.C., 2006, Conservation value of clustered housing developments: Conservation Biology, v. 20, no. 5, p. 1445-1456. [Also available at https://doi.org/10.1111/j.1523-1739.2006.00491.x.]

Lipsey, M.K., 2015, Cows and plows-Science-based conservation for grassland songbirds in agricultural landscapes: Missoula, Mont., University of Montana, Ph.D. Dissertation, $137 \mathrm{p}$.

Lipsey, M.K., and Naugle, D.E., 2017, Precipitation and soil productivity explain effects of grazing on grassland songbirds: Rangeland Ecology and Management, v. 70, no. 3, p. 331-340. [Also available at https://doi.org/10.1016/j. rama.2016.10.010.]

Lloyd, J., Mannan, R.W., DeStefano, S., and Kirkpatrick, C., 1998, Effects of mesquite invasion on a southeastern Arizona grassland bird community: The Wilson Bulletin, v. 110 , no. 3 , p. $403-408$.

Lockhart, J., and Koper, N., 2018, Northern prairie songbirds are more strongly influenced by grassland configuration than grassland amount: Landscape Ecology, v. 33, no. 9, p. 1543-1558. [Also available at https://doi.org/10.1007/ s10980-018-0681-5.] 
Lokemoen, J.T., and Beiser, J.A., 1997, Bird use and nesting in conventional, minimum-tillage, and organic cropland: The Journal of Wildlife Management, v. 61, no. 3, p. 644655. [Also available at https://doi.org/10.2307/3802172.]

Londe, D.W., Fuhlendorf, S.D., Elmore, R.D., and Davis, C.A., 2019, Landscape heterogeneity influences the response of grassland birds to energy development: Wildlife Biology, v. 2019, no. 1, p. 1-11. [Also available at https:// doi.org/10.2981/wlb.00523.]

Long, A.M., Jensen, W.E., and With, K.A., 2009, Orientation of Grasshopper Sparrow and Eastern Meadowlark nests in relation to wind direction: The Condor, v. 111, no. 2, p. 395-399. [Also available at https://doi.org/10.1525/ cond.2009.080076.]

Longcore, T., Rich, C., Mineau, P., MacDonald, B., Bert, D.G., Sullivan, L.M., Mutrie, E., Gauthreaux, S.A., Jr., Avery, M.L., Crawford, R.L., Manville, A.M., II, Travis, E.R., and Drake, D., 2013, Avian mortality at communication towers in the United States and Canada-Which species, how many, and where?: Biological Conservation, v. 158, p. 410-419. [Also available at https://doi.org/10.1016/j. biocon.2012.09.019.]

Loss, S.R., Will, T., and Marra, P.P., 2013, Estimates of bird collision mortality at wind facilities in the contiguous United States: Biological Conservation, v. 168, p. 201-209. [Also available at https://doi.org/10.1016/j. biocon.2013.10.007.]

Lueders, A.S., Kennedy, P.L., and Johnson, D.H., 2006, Influences of management regimes on breeding bird densities and habitat in mixed-grass prairie-An example from North Dakota: The Journal of Wildlife Management, v. 70, no. 2, p. 600-606. [Also available at https://doi.org/10.2193/0022541X(2006)70\%5B600:IOMROB\%5D2.0.CO;2.]

Lyons, T.P., Miller, J.R., Debinski, D.M., and Engle, D.M., 2015, Predator identity influences the effect of habitat management on nest predation: Ecological Applications, v. 25, no. 6, p. 1596-1605. [Also available at https://doi. org/10.1890/14-1641.1.]

Mack, W.M., 2017, Grassland birds-Community dynamics, resource selection, and nest survival on mixed-grass prairie grazed by native colonial and domestic herbivores: Fargo, N. Dak., North Dakota State University, Master's Thesis, $64 \mathrm{p}$.

Madden, E.M., 1996, Passerine communities and bird-habitat relationships on prescribe-burned, mixed-grass prairie in North Dakota: Bozeman, Mont., Montana State University, Master's Thesis, $153 \mathrm{p}$.
Madden, E.M., Hansen, A.J., and Murphy, R.K., 1999, Influence of prescribed fire history on habitat and abundance of passerine birds in northern mixed-grass prairie: Canadian Field-Naturalist, v. 113, no. 4, p. 627-640.

Madden, E.M., Murphy, R.K., Hansen, A.J., and Murray, L., 2000, Models for guiding management of prairie bird habitat in northwestern North Dakota: American Midland Naturalist, v. 144, no. 2, p. 377-392. [Also available at https://doi.org/10.1674/0003-0031(2000)144\%5B0377:MF GMOP\%5D2.0.CO;2.]

Mattice, J.A., Brauning, D.W., and Diefenbach, D.R., 2005, Abundance of grassland sparrows on reclaimed surface mines in western Pennsylvania, in Ralph, C.J., and Rich, T.D., eds., Bird conservation implementation and integration in the Americas-Proceedings of the third International Partners in Flight Conference: Albany, Calif., U.S. Dept. of Agriculture, Forest Service, General Technical Report PSWGTR-191, p. 504-510.

McCoy, T.D., Ryan, M.R., and Kurzejeski, E.W., 2001, Grassland bird conservation-CP1 vs. CP2 plantings in Conservation Reserve Program fields in Missouri: American Midland Naturalist, v. 145, no. 1, p. 1-17. [Also available at https://doi.org/10.1674/0003-0031(2001)145[0001:GBCCV C]2.0.CO;2.]

McCoy, T.D., Ryan, M.R., Kurzejeski, E.W., and Burger, L.W., Jr., 1999, Conservation Reserve Program-Source or sink habitat for grassland birds in Missouri?: The Journal of Wildlife Management, v. 63, no. 2, p. 530-538. [Also available at https://doi.org/10.2307/3802639.]

McLachlan, M.M., 2007, Habitat use by birds in the northern shortgrass prairie of North America-A local and landscape approach: Stillwater, Okla., Oklahoma State University, Master's Thesis, $87 \mathrm{p}$.

McLaughlin, M.E., Janousek, W.M., McCarty, J.P., and Wolfenbarger, L.L., 2014, Effects of urbanization on site occupancy and density of grassland birds in tallgrass prairie fragments: Journal of Field Ornithology, v. 85, no. 3, p. 258-273. [Also available at https://doi.org/10.1111/ jofo.12066.]

McMaster, D.G., and Davis, S.K., 2001, An evaluation of Canada's Permanent Cover Program-Habitat for grassland birds?: Journal of Field Ornithology, v. 72, no. 2, p. 195210. [Also available at https://doi.org/10.1648/0273-857072.2.195.] 
McMaster, D.G., Devries, J.H., and Davis, S.K., 1999, An integrated evaluation of cropland conversion in the Missouri Coteau of Saskatchewan-Productivity of pintail and other grassland birds: Regina, Saskatchewan, Saskatchewan Wetland Conservation Corporation; Oak Hammock Marsh, Manitoba, Institute for Wetland and Waterfowl Research; Oak Hammock Marsh, Manitoba, Ducks Unlimited Canada, $11 \mathrm{p}$.

McMullen, C.M., and Harms, T.M., 2020, Impact of delayed mowing on restoring populations of grassland birds of conservation concern: Ecological Restoration, v. 38, no. 2, p. 77-82. [Also available at https://doi.org/10.3368/ er.38.2.77.]

Messmer, T.A., 1990, Influence of grazing treatments on nongame birds and vegetation structure in south central North Dakota: Fargo, N. Dak., North Dakota State University, Ph.D. Dissertation, 164 p.

Miller, R.A., Bond, L., Migas, P.N., Carlisle, J.D., and Kaltenecker, G.S., 2017, Contrasting habitat associations of sagebrush-steppe songbirds in the Intermountain West: Western Birds, v. 48, no. 1, p. 35-55. [Also available at https://doi.org/10.21199/WB481.3.]

Mineau, P., Downes, C.M., Kirk, D.A., Bayne, E., and Csizy, M., 2005, Patterns of bird species abundance in relation to granular insecticide use in the Canadian prairies: Ecoscience, v. 12, no. 2, p. 267-278. [Also available at https://doi. org/10.2980/i1195-6860-12-2-267.1.]

Mineau, P., and Whiteside, M., 2013, Pesticide acute toxicity is a better correlate of U.S. grassland bird declines than agricultural intensification: PLoS One, v. 8, no. 2, p. e57457. [Also available at https://doi.org/10.1371/journal.pone.0057457.]

Murray, L.D., and Best, L.B., 2003, Short-term bird response to harvesting switchgrass for biomass in Iowa: The Journal of Wildlife Management, v. 67, no. 3, p. 611-621. [Also available at https://doi.org/10.2307/3802718.]

Murray, L.D., Best, L.B., Jacobsen, T.J., and Braster, M.L., 2003, Potential effects on grassland birds of converting marginal cropland to switchgrass biomass production: Biomass and Bioenergy, v. 25, no. 2, p. 167-175. [Also available at https://doi.org/10.1016/S0961-9534(02)00187-3.]

Murray, L.D., Ribic, C.A., and Thogmartin, W.E., 2008, Relationship of obligate grassland birds to landscape structure in Wisconsin: The Journal of Wildlife Management, v. 72, no. 2, p. 463-467. [Also available at https://doi. org/10.2193/2006-556.]

National Geographic Society, 2011, Field guide to the birds of North America (6th ed.): Washington, D.C., National Geographic Society, 576 p.
Negus, L.P., Davis, C.A., and Wessel, S.E., 2010, Avian response to mid-contract management of Conservation Reserve Program fields: American Midland Naturalist, v. 164, no. 2, p. 296-310. [Also available at https://doi. org/10.1674/0003-0031-164.2.296.]

Niemuth, N.D., Estey, M.E., Fields, S.P., Wangler, B., Bishop, A.A., Moore, P.J., Grosse, R.C., and Ryba, A.J., 2017, Developing spatial models to guide conservation of grassland birds in the U.S. northern Great Plains: The Condor, v. 119, no. 3, p. 506-525. [Also available at https://doi. org/10.1650/CONDOR-17-14.1.]

Niemuth, N.D., Solberg, J.W., and Shaffer, T.L., 2008, Influence of moisture on density and distribution of grassland birds in North Dakota: The Condor, v. 110, no. 2, p. 211-222. [Also available at https://doi.org/10.1525/ cond.2008.8514.]

Nixon, A.E., Fisher, R.J., Stralberg, D., Bayne, E.M., and Farr, D.R., 2016, Projected responses of North American grassland songbirds to climate change and habitat availability at their northern range limits in Alberta, Canada: Avian Conservation and Ecology, v. 11, no. 2, article 2, p. 1-14. [Also available at https://doi.org/10.5751/ACE-00866-110202.]

O’Leary, C.H., and Nyberg, D.W., 2000, Treelines between fields reduce the density of grassland birds: Natural Areas Journal, v. 20, no. 3, p. 243-249.

Olechnowski, B.F.M., Debinski, D.M., Drobney, P., VisteSparkman, K., and Reed, W.T., 2009, Changes in vegetation structure through time in a restored tallgrass prairie ecosystem and implications for avian diversity and community composition: Ecological Restoration, v. 27, no. 4, p. 449-457. [Also available at https://doi.org/10.3368/ er.27.4.449.]

Osborne, D.C., and Sparling, D.W., 2013, Multi-scale associations of grassland birds in response to cost-share management of Conservation Reserve Program fields in Illinois: The Journal of Wildlife Management, v. 77, no. 5, p. 920930. [Also available at https://doi.org/10.1002/jwmg.553.]

Patten, M.A., Reinking, D.L., and Wolfe, D.H., 2011, Hierarchical cues in brood parasite nest selection: Journal of Ornithology, v. 152, no. 3, p. 521-532. [Also available at https://doi.org/10.1007/s10336-010-0608-7.]

Patten, M.A., Shochat, E., Reinking, D.L., Wolfe, D.H., and Sherrod, S.K., 2006, Habitat edge, land management, and rates of brood parasitism in tallgrass prairie: Ecological Applications, v. 16, no. 2, p. 687-695. [Also available at https://doi.org/10.1890/1051-0761(2006)016\%5B0687:HEL MAR\%5D2.0.CO;2.] 
Patterson, M.P., and Best, L.B., 1996, Bird abundance and nesting success in Iowa CRP fields-The importance of vegetation structure and composition: American Midland Naturalist, v. 135 , no. 1, p. 153-167. [Also available at https://doi.org/10.2307/2426881.]

Peer, B.D., Robinson, S.K., and Herkert, J.R., 2000, Egg rejection by cowbird hosts in grasslands: The Auk, v. 117, no. 4, p. 892-901. [Also available at https://doi. org/10.2307/4089628.]

Piehler, K.G., 1987, Habitat relationships of three grassland sparrow species on reclaimed surface mines in Pennsylvania: Morgantown, W. Va., West Virginia University, Master's Thesis, 78 p.

Pillsbury, F.C., 2010, Grassland bird responses to a firegrazing interaction in a fragmented landscape: Ames, Iowa, Iowa State University, Ph.D. Dissertation, 114 p.

Pillsbury, F.C., Miller, J.R., Debinski, D.M., and Engle, D.M., 2011, Another tool in the toolbox? Using fire and grazing to promote bird diversity in highly fragmented landscapes: Ecosphere, v. 2, no. 3, article 28. [Also available at https:// doi.org/10.1890/ES10-00154.1.]

Powell, A.F.L.A., 2006, Effects of prescribed burns and bison (Bos bison) grazing on breeding bird abundance in tallgrass prairie: The Auk, v. 123, no. 1, p. 183-197. [Also available at https://doi.org/10.1642/0004-8038(2006)123\%5B0183:E OPBAB\%5D2.0.CO;2.]

Powell, A.F.L.A., 2008, Responses of breeding birds in tallgrass prairie to fire and cattle grazing: Journal of Field Ornithology, v. 79, no. 1, p. 41-52. [Also available at https://doi. org/10.1111/j.1557-9263.2008.00144.x.]

Powell, A.F.L.A., and Busby, W.H., 2013, Effects of grassland management on breeding birds at the western edge of the tallgrass prairie ecosystem in Kansas: Natural Areas Journal, v. 33, no. 2, p. 130-138. [Also available at https://doi. org/10.3375/043.033.0202.]

Prescott, D.R.C., 1997, Avian communities and NAWMP habitat priorities in the northern prairie biome of Alberta: St. Albert, Alberta, Land Stewardship Centre of Canada, NAWMP-029, $41 \mathrm{p}$.

Prescott, D.R.C., and Wagner, G.M., 1996, Avian responses to implementation of a complementary/rotational grazing system by the North American Waterfowl Management Plan in southern Alberta-The Medicine Wheel Project: Edmonton, Alberta, Alberta NAWMP Centre, NAWMP-018, 24 p.

Quamen, F.R., 2007, A landscape approach to grassland bird conservation in the Prairie Pothole Region of the northern Great Plains: Missoula, Mont., University of Montana, Ph.D. Dissertation, 149 p.
Quinn, J.E., Awada, T., Trinidade, F., Fulginiti, L., and Perrin, R., 2017, Combining habitat loss and agricultural intensification improves our understanding of drivers of change in avian abundance in a North American cropland anthrome: Ecology and Evolution, v. 7, no. 3, p. 803-814. [Also available at https://doi.org/10.1002/ece3.2670.]

Quinn, J.E., Brandle, J.R., and Johnson, R.J., 2012, The effects of land sparing and wildlife-friendly practices on grassland bird abundance within organic farmlands: Agriculture, Ecosystems and Environment, v. 161, p. 10-16. [Also available from https://doi.org/10.1016/j.agee.2012.07.021.]

Rahmig, C.J., Jensen, W.E., and With, K.A., 2009, Grassland bird responses to land management in the largest remaining tallgrass prairie: Conservation Biology, v. 23, no. 2, p. 420-432. [Also available at https://doi.org/10.1111/ j.1523-1739.2008.01118.x.]

Rao, D., Gennet, S., Hammond, M., Hopkinson, P., and Bartolome, J., 2008, A landscape analysis of grassland birds in a valley grassland-oak woodland mosaic, in Merenlender, A., McCreary, D., and Purcell, K.L., eds., Proceedings of the Sixth Symposium on Oak Woodlands-Today's challenges, tomorrow's opportunities: Albany, California, U.S. Department of Agriculture, Forest Service, Pacific Southwest Research Station, General Technical Report PSW-GTR-217, p. 385-397.

Reinking, D.L., Wolfe, D.H., and Sherrod, S.K., 2009, Nest monitoring, point counts, and habitat of tallgrass prairie breeding birds of northeastern Oklahoma, 1992-1996: Oklahoma Biological Survey, v. 9, no. 1, p. 1-12.

Renfrew, R.B., and Ribic, C.A., 2002, Influence of topography on density of grassland passerines in pastures: American Midland Naturalist, v. 147, no. 2, p. 315-325. [Also available at https://doi.org/10.1674/0003-0031(2002)147\%5B03 15:IOTODO\%5D2.0.CO;2.]

Renfrew, R.B., and Ribic, C.A., 2008, Multi-scale models of grassland passerine abundance in a fragmented system in Wisconsin: Landscape Ecology, v. 23, no. 2, p. 181-193. [Also available at https://doi.org/10.1007/s10980-007-91792.]

Renfrew, R.B., Ribic, C.A., and Nack, J.L., 2005, Edge avoidance by nesting grassland birds - A futile strategy in a fragmented landscape: The Auk, v. 122, no. 2, p. 618-636. [Also available at https://doi.org/10.1642/00048038(2005)122\%5B0618:EABNGB\%5D2.0.CO;2.]

Renken, R.B., 1983, Breeding bird communities and birdhabitat associations on North Dakota waterfowl production areas of three habitat types: Ames, Iowa, Iowa State University, Master's Thesis, $90 \mathrm{p}$. 
Renken, R.B., and Dinsmore, J.J., 1987, Nongame bird communities on managed grasslands in North Dakota: Canadian Field-Naturalist, v. 101, no. 4, p. 551-557.

Ribic, C.A., Guzy, M.J., Anderson, T.J., Sample, D.W., and Nack, J., 2012, Bird productivity and nest predation in agricultural grasslands, in Ribic, C.A., Thompson, F.R., III, and Pietz, P.J., eds., Video surveillance of nesting birds: Berkeley, Calif., University of California Press, Studies in Avian Biology, v. 43, p. 119-134. [Also available at https:// doi.org/10.1525/california/9780520273139.003.0010.]

Ribic, C.A., Guzy, M.J., and Sample, D.W., 2009a, Grassland bird use of remnant prairie and Conservation Reserve Program fields in an agricultural landscape in Wisconsin: American Midland Naturalist, v. 161, no. 1, p. 110-122. [Also available at https://doi.org/10.1674/0003-0031161.1.110.]

Ribic, C.A., Koford, R.R., Herkert, J.R., Johnson, D.H., Niemuth, N.D., Naugle, D.E., Bakker, K.K., Sample, D.W., and Renfrew, R.B., 2009b, Area sensitivity in North American grassland birds-Patterns and processes: The Auk, v. 126, no. 2, p. 233-244. [Also available at https://doi.org/10.1525/ auk.2009.1409.]

Ribic, C.A., and Sample, D.W., 2001, Associations of grassland birds with landscape factors in southern Wisconsin: American Midland Naturalist, v. 146, no. 1, p. 105-121. [Also available at https://doi.org/10.1674/00030031(2001)146\%5B0105:AOGBWL\%5D2.0.CO;2.]

Richardson, A.N., 2012, Changes in grassland songbird abundances through time in response to burning and grazing in the northern mixed-grass prairie: Winnipeg, Manitoba, University of Manitoba, Master's Thesis, $73 \mathrm{p}$.

Richardson, A.N., Koper, N., and White, K.A., 2014, Interactions between ecological disturbances-Burning and grazing and their effects on songbird communities in northern mixed-grass prairies: Avian Conservation and Ecology, v. 9, no. 2, article 5. [Also available at https://doi.org/10.5751/ ACE-00692-090205.]

Riffell, S., Scognamillo, D., and Burger, L.W., 2008, Effects of the Conservation Reserve Program on Northern Bobwhite and grassland birds: Environmental Monitoring and Assessment, v. 146 , no. $1-3$, p. $309-323$. [Also available at https:// doi.org/10.1007/s10661-007-0082-8.]

Riffell, S., Scognamillo, D., Burger, L.W., Jr., and Bucholtz, S., 2010, Broad-scale relations between Conservation Reserve Program and grassland birds-Do cover type, configuration, and contract age matter?: The Open Ornithology Journal, v. 3, p. 112-123. [Also available at https://doi.org/1 0.2174/1874453201003010112.]
Robel, R.J., Briggs, J.N., Dayton, A.D., and Hulbert, L.C., 1970, Relationships between visual obstruction measurements and weight of grassland vegetation: Journal of Range Management, v. 23, no. 4, p. 295-297. [Also available at https://doi.org/10.2307/3896225.]

Robel, R.J., Hughes, J.P., Hull, S.D., Kemp, K.E., and Klute, D.S., 1998, Spring burning - Resulting avian abundance and nesting in Kansas CRP: Journal of Range Management, v. 51, no. 2, p. 132-138. [Also available at https://doi. org/10.2307/4003197.]

Roberts, A.J., Boal, C.W., Wester, D.B., Rideout-Hanzak, S., and Whitlaw, H.A., 2012, Grassland bird community response to large wildfires: The Wilson Journal of Ornithology, v. 124, no. 1, p. 24-30. [Also available at https://doi. org/10.1676/10-177.1.]

Roberts, A.J., Boal, C.W., and Whitlaw, H.A., 2017, Nesting ecology of grassland birds following a wildfire in the southern Great Plains: The Southwestern Naturalist, v. 62, no. 1, p. 39-45. [Also available at https://doi.org/10.1894/00384909-62.1.39.]

Rockwell, S.M., Wehausen, B., Johnson, P.R., Kristof, A., Stephens, J.L., Alexander, J.D., and Barnett, J.K., 2021, Sagebrush bird communities differ with varying levels of crested wheatgrass invasion: Journal of Fish and Wildlife Management online early. [Also available at https://doi. org/10.3996/JFWM-20-035.]

Rodenhouse, N.L., Best, L.B., O'Connor, R.J., and Bollinger, E.K., 1995, Effects of agricultural practices and farmland structures on Neotropical migratory birds, in Martin, T.E., and Finch, D.M., eds., Ecology and management of Neotropical migratory birds-A synthesis and review of critical issues: New York, N.Y., Oxford University Press, p. 269-293.

Rohrbaugh, R.W., Jr., Reinking, D.L., Wolfe, D.H., Sherrod, S.K., and Jenkins, M.A., 1999, Effects of prescribed burning and grazing on nesting and reproductive success of three grassland passerine species in tallgrass prairie, in Vickery, P.D., and Herkert, J.R., eds., Ecology and conservation of grassland birds of the Western Hemisphere: Studies in Avian Biology, v. 19, p. 165-170.

Rotenberry, J.T., and Wiens, J.A., 1980, Habitat structure, patchiness, and avian communities in North American steppe vegetation-A multivariate analysis: Ecology, v. 61 , no. 5, p. 1228-1250. [Also available at https://doi. org/10.2307/1936840.]

Roth, A.M., Sample, D.W., Ribic, C.A., Paine, L., Undersander, D.J., and Bartelt, G.A., 2005, Grassland bird response to harvesting switchgrass as a biomass energy crop: Biomass and Bioenergy, v. 28, no. 5, p. 490-498. [Also available at https://doi.org/10.1016/j.biombioe.2004.11.001.] 
Ruth, J.M., 2008, Distribution and abundance of breeding Arizona Grasshopper Sparrow (Ammodramus savannarum ammolegus) in the southwestern United States-Past, present, and future, in Ruth, J.M., Brush, T., and Krueper, D., eds., Birds of the US-Mexico borderlands-Distribution, ecology, and conservation-Studies in Avian Biology v. 37, p. 113-124.

Ruth, J.M., 2015, Status Assessment and Conservation Plan for the Grasshopper Sparrow (Ammodramus savannarum). Version 1.0. U.S. Fish and Wildlife Service, Lakewood, Colo., 109 p., accessed February 2021 at https://digitalcommons.unl.edu/usfwspubs/471/.

Ruth, J.M., 2017, Life history attributes of Arizona Grasshopper Sparrows (Ammodramus savannarum ammolegus) and comparisons with other North American subspecies: American Midland Naturalist, v. 178, no. 1, p. 64-81. [Also available at https://doi.org/10.1674/0003-0031-178.1.64.]

Ruth, J.M., and Skagen, S.K., 2017, Territory and nest site selection patterns by Grasshopper Sparrows in southeastern Arizona: The Condor, v. 119, no. 1, p. 469-483. [Also available at https://doi.org/10.1650/CONDOR-16-210.1.]

Ruth, J.M., and Skagen, S.K., 2018, Reproductive response of Arizona Grasshopper Sparrows to weather patterns and habitat structure: The Condor, v. 120, no. 3, p. 596-616. [Also available at https://doi.org/10.1650/CONDOR-17-128.1.]

Ruth, J.M., Talbot, W.A., and Smith, E.K., 2020, Behavioral response to high temperatures in a desert grassland birdUse of shrubs as thermal refugia: Western North American Naturalist, v. 80 , no. 2, p. 265-275. [Also available at https://doi.org/10.3398/064.080.0215.]

Salo, E.D., Higgins, K.F., Patton, B.D., Bakker, K.K., and Barker, W.T., 2004, Grazing intensity effects on vegetation, livestock and non-game birds in North Dakota mixed-grass prairie, in Egan, D., and Harrington, J.A., eds., Proceedings of the nineteenth North American Prairie Conference: Madison, Wis., University of Wisconsin, p. 205-215.

Sample, D.W., 1989, Grassland birds in southern Wisconsin-Habitat preference, population trends, and response to land use changes: Madison, Wis., University of Wisconsin, Master's Thesis, $588 \mathrm{p}$.

Sauer, J.R., Hines, J.E., Fallon, J.E., Pardieck, K.L., Ziolkowski, D.J., Jr., and Link, W.A., 2014, The North American Breeding Bird Survey, results and analysis 1966-2012 (ver. 02.19.2014): Laurel, Md., U.S. Geological Survey, Patuxent Wildlife Research Center, accessed June 2020 at https://www.mbr-pwrc.usgs.gov/bbs/bbs2012.shtml.

Scheiman, D.M., Bollinger, E.K., and Johnson, D.H., 2003, Effects of leafy spurge infestation on grassland birds: The Journal of Wildlife Management, v. 67, no. 1, p. 115-121. [Also available at https://doi.org/10.2307/3803067.]
Schmidt, J.A., Washburn, B.E., DeVault, T.L., and Seamans, T.W., 2013, Do native warm-season grasslands near airports increase bird strike hazards?: American Midland Naturalist, v. 170, no. 1, p. 144-157. [Also available https://doi. org/10.1674/0003-0031-170.1.144.]

Schneider, N.A., 1998, Passerine use of grasslands managed with two grazing regimes on the Missouri Coteau in North Dakota: Brookings, S. Dak., South Dakota State University, Master's Thesis, $94 \mathrm{p}$.

Schulte, L.A., MacDonald, A.L., Niemi, J.B., and Helmers, M.J., 2016, Prairie strips as a mechanism to promote land sharing by birds in industrial agricultural landscapes: Agriculture, Ecosystems and Environment, v. 220, p. 55-63. [Also available at https://doi.org/10.1016/j. agee.2016.01.007.]

Scott, P.E., DeVault, T.L., Bajema, R.A., and Lima, S.L., 2002, Grassland vegetation and bird abundances on reclaimed midwestern coal mines: Wildlife Society Bulletin, v. 30, no. 4, p. 1006-1014.

Seigel, A., and Lockwood, J., 2010, How increasing levels of private land enrollment in conservation agreements affect the population viability of grassland birds: Biodiversity and Conservation, v. 19, no. 8, p. 2343-2357. [Also available at https://doi.org/10.1007/s10531-010-9837-6.]

Shaffer, J.A., and Buhl, D.A., 2016, Effects of wind-energy facilities on breeding grassland bird distributions: Conservation Biology, v. 30, no. 1, p. 59-71. [Also available at https://doi.org/10.1111/cobi.12569.]

Shaffer, J.A., Igl, L.D., and Johnson, D.H., 2019a, The effects of management practices on grassland birds-Rates of Brown-headed Cowbird (Molothrus ater) parasitism in nests of North American grassland birds, chap. PP of Johnson, D.H., Igl, L.D., Shaffer, J.A., and DeLong, J.P., eds., The effects of management practices on grassland birds: U.S. Geological Survey Professional Paper 1842, 24 p., accessed March 2021 at https://doi.org/10.3133/pp1842PP.

Shaffer, J.A., Loesch, C.R., and Buhl, D.A., 2019b, Estimating offsets for avian displacement effects of anthropogenic impacts: Ecological Applications, v. 29, no. 8, p. e01983. [Also available at https://doi.org/10.1002/eap.1983.]

Shaffer, J.A., Roth, C.L., and Mushet, D.M., 2019c, Modeling effects of crop production, energy development and conservation-grassland loss on avian habitat: PLoS One, v. 14, no. 1, p. e0198382. [Also available at https://doi. org/10.1371/journal.pone.0198382.]

Shahan, J.L., Goodwin, B.J., and Rundquist, B.C., 2017, Grassland songbird occurrence on remnant prairie patches is primarily determined by landscape characteristics: Landscape Ecology, v. 32, no. 5, p. 971-988. [Also available at https://doi.org/10.1007/s10980-017-0500-4.] 
Shaw, M.R., Klausmeyer, K., Cameron, D.R., MacKenzie, J., and Roehrdanz, P., 2012, Economic costs of achieving current conservation goals in the future as climate changes: Conservation Biology, v. 26, no. 3, p. 385-396. [Also available at https://doi.org/10.1111/j.1523-1739.2012.01824.x.]

Skinner, R.M., 1974, Grassland use patterns and prairie bird populations in Missouri: Columbia, Mo., University of Missouri, Master's Thesis, $53 \mathrm{p}$.

Skinner, S.P., 2004, Linking decision support systems for ducks with relative abundance of other grassland bird species: Saskatoon, Saskatchewan, University of Saskatchewan, Master's Thesis, 115 p.

Skipper, C.S., 1998, Henslow's Sparrows return to previous nest site in western Maryland: North American Bird Bander, v. 23 , no. 2 , p. $36-41$.

Sliwinski, M.S., 2011, Changes in grassland songbird abundance and diversity in response to grazing by bison and cattle in the northern mixed-grass prairie: Winnipeg, Manitoba, University of Manitoba, Master's Thesis, $156 \mathrm{p}$.

Sliwinski, J.S., Powell, L.A., and Schacht, W.H., 2019, Grazing systems do not affect bird habitat on a Sandhills landscape: Rangeland Ecology and Management, v. 72, no. 1, p. 136-144. [Also available at https://doi.org/10.1016/j. rama.2018.07.006.]

Sliwinski, J.S., Powell, L.A., and Schacht, W.H., 2020, Similar bird communities across grazing systems in the Nebraska Sandhills: The Journal of Wildlife Management, v. 84, no. 4, p. 802-812. [Also available at https://doi.org/10.1002/ jwmg.21825.]

Small, D.M., Blank, P.J., and Lohr, B., 2015, Habitat use and movement patterns by dependent and independent juvenile Grasshopper Sparrows during the post-fledging period: Journal of Field Ornithology, v. 86, no. 1, p. 17-26. [Also available at https://doi.org/10.1111/jofo.12085.]

Small, D.M., Gimpel, M.E., Parks, J., Guerard, J.B., and Gill, D.E., 2009, First documented cases of polygyny in the Grasshopper Sparrow: The Wilson Journal of Ornithology, v. 121, no. 4, p. 822-825. [Also available at https://doi. org/10.1676/09-021.1.]

Smith, G.A., and Lomolino, M.V., 2004, Black-tailed prairie dogs and the structure of avian communities on the shortgrass plains: Oecologia, v. 138, no. 4, p. 592-602. [Also available at https://doi.org/10.1007/s00442-003-1465-3.]

Smith, R.L., 1963, Some ecological notes on the Grasshopper Sparrow: The Wilson Bulletin, v. 75, no. 2, p. 159-165.
Smith, R.L., 1968, Grasshopper Sparrow (Ammodramus savannarum), in Austin, O.L., Jr., ed., Life histories of North American cardinals, grosbeaks, buntings, towhees, finches, sparrows, and allies. Order Passeriformes-Family Fringillidae. Part two-Genera Pipilo (part) through Spizella: New York, N.Y., Dover Publications, Inc., p. 725-745. [Also available at https://doi.org/10.5479/ si.03629236.237.1.]

Smythe, L.A., 2006, Response of nesting grassland birds to sand shinnery oak communities treated with tebuthiuron and grazing in eastern New Mexico: Lubbock, Tex., Texas Tech University, Master's Thesis, $105 \mathrm{p}$.

Smythe, L.A., and Haukos, D.A., 2010, Response of grassland birds in sand shinnery oak communities restored using tebuthiuron and grazing in eastern New Mexico: Restoration Ecology, v. 18, no. 2, p. 215-223. [Also available at https://doi.org/10.1111/j.1526-100X.2008.00443.x.]

Soha, J.A., Lohr, B., and Gill, D.E., 2009, Song development in the Grasshopper Sparrow, Ammodramus savannarum: Animal Behaviour, v. 77, no. 6, p. 1479-1489. [Also available at https://doi.org/10.1016/j.anbehav.2009.02.021.]

Stallman, H.R., and Best, L.B., 1996, Bird use of an experimental strip intercropping system in northeast Iowa: The Journal of Wildlife Management, v. 60, no. 2, p. 354-362. [Also available at https://doi.org/10.2307/3802235.]

Stauffer, G.E., Diefenbach, D.R., Marshall, M.R., and Brauning, D.W., 2011, Nest success of grassland sparrows on reclaimed surface mines: The Journal of Wildlife Management, v. 75, no. 3, p. 548-557. [Also available at https://doi. org/10.1002/jwmg.70.]

Stewart, R.E., 1975, Breeding birds of North Dakota: Fargo, N. Dak., Tri-College Center for Environmental Studies, $295 \mathrm{p}$.

Stuber, E.F., and Fontaine, J.J., 2018, Ecological neighborhoods as a framework for umbrella species selection: Biological Conservation, v. 233, p. 112-119. [Also available at https://doi.org/10.1016/j.biocon.2018.04.026.]

Sullivan, B.L., Wood, C.L., Iliff, M.J., Bonney, R.E., Fink, D., and Kelling, S., 2009, eBird-A citizen-based bird observation network in the biological sciences: Biological Conservation, v. 142, no. 10, p. 2282-2292. [Also available at https://doi.org/10.1016/j.biocon.2009.05.006.]

Sutter, B., and Ritchison, G., 2005, Effects of grazing on vegetation structure, prey availability, and reproductive success of Grasshopper Sparrows: Journal of Field Ornithology, v. 76 , no. 4, p. 345-351. [Also available at https://doi. org/10.1648/0273-8570-76.4.345.] 
Sutter, G.C., and Brigham, R.M., 1998, Avifaunal and habitat changes resulting from conversion of native prairie to crested wheatgrass - Patterns at songbird community and species levels: Canadian Journal of Zoology, v. 76, no. 5, p. 869-875. [Also available at https://doi.org/10.1139/z98018.]

Swengel, S.R., 1996, Management responses of three species of declining sparrows in tallgrass prairie: Bird Conservation International, v. 6, no. 3, p. 241-253. [Also available at https://doi.org/10.1017/S0959270900003130.]

Swengel, S.R., and Swengel, A.B., 2001, Relative effects of litter and management on grassland bird abundance in Missouri, USA: Bird Conservation International, v. 11, no. 2, p. 113-128. [Also available at https://doi.org/10.1017/ S095927090100020X.]

Tack, J.D., Quamen, F.R., Kelsey, K., and Naugle, D.E., 2017, Doing more with less-Removing trees in a prairie system improves value of grasslands for obligate bird species: Journal of Environmental Management, v. 198, no. 1, p. 163-169. [Also available at https://doi.org/10.1016/j. jenvman.2017.04.044.]

Temple, S.A., Fevold, B.M., Paine, L.K., Undersander, D.J., and Sample, D.W., 1999, Nesting birds and grazing cattleAccommodating both on midwestern pastures, in Vickery, P.D., and Herkert, J.R., eds., Ecology and conservation of grassland birds of the Western Hemisphere: Studies in Avian Biology, v. 19, p. 196-202.

Thogmartin, W.E., Knutson, M.G., and Sauer, J.R., 2006, Predicting regional abundance of rare grassland birds with a hierarchical spatial count model: The Condor, v. 108, no. 1, p. 25-46. [Also available at https://doi.org/10.1650/00105422(2006)108\%5B0025:PRAORG\%5D2.0.CO;2.]

Thompson, S.J., Johnson, D.H., Niemuth, N.D., and Ribic, C.A., 2015, Avoidance of unconventional oil wells and roads exacerbates habitat loss for grassland birds in the North American Great Plains: Biological Conservation, v. 192, p. 82-90. [Also available at https://doi.org/10.1016/j. biocon.2015.08.040.]

Thompson, T.R., Boal, C.W., and Lucia, D., 2009, Grassland bird associations with introduced and native grass Conservation Reserve Program fields in the Southern High Plains: Western North American Naturalist, v. 69 , no. 4, p. 481-490. [Also available at https://doi. org/10.3398/064.069.0408.]

Trail, P.W., 2006, Avian mortality at oil pits in the United States-A review of the problem and efforts for its solution: Environmental Management, v. 38, no. 4, p. 532-544. [Also available at https://doi.org/10.1007/s00267-005-0201-7.]
Uden, D.R., 2012, Agricultural landuse change impacts on bioenergy production, avifauna, and water use in Nebraska's Rainwater Basin: Lincoln, Nebr., University of Nebraska, Master's Thesis, $250 \mathrm{p}$.

Uden, D.R., Allen, C.R., Mitchell, R.B., McCoy, T.D., and Guan, Q., 2015, Predicted avian responses to bioenergy development scenarios in an intensive agricultural landscape: Global Change Biology. Bioenergy, v. 7, no. 4, p. 717-726. [Also available at https://doi.org/10.1111/ gcbb.12157.]

Vander Haegen, W.M., Dobler, F.C., and Pierce, D.J., 2000, Shrubsteppe bird response to habitat and landscape variables in eastern Washington, U.S.A.: Conservation Biology, v. 14, no. 4, p. 1145-1160. [Also available at https://doi. org/10.1046/j.1523-1739.2000.99293.x.]

Van Dyke, F., Schmeling, J.D., Starkenburg, S., Yoo, S.H., and Stewart, P.W., 2007, Responses of plant and bird communities to prescribed burning in tallgrass prairies: Biodiversity and Conservation, v. 16, no. 4, p. 827-839. [Also available at https://doi.org/10.1007/s10531-006-9107-9.]

Van Dyke, F., Van Kley, S.E., Page, C.E., and Van Beek, J.G., 2004, Restoration efforts for plant and bird communities in tallgrass prairies using prescribed burning and mowing: Restoration Ecology, v. 12, no. 4, p. 575-585. [Also available at https://doi.org/10.1111/j.1061-2971.2004.00352.x.]

Veech, J.A., 2006, A comparison of landscapes occupied by increasing and decreasing populations of grassland birds: Conservation Biology, v. 20, no. 5, p. 1422-1432. [Also available at https://doi.org/10.1111/j.15231739.2006.00487.x.]

Vickery, P.D., 1993, Habitat selection of grassland birds in Maine: Orono, Maine, University of Maine, Ph.D. Dissertation, $124 \mathrm{p}$.

Vickery, P.D., 2020, Grasshopper Sparrow (Ammodramus savannarum) (ver. 1.0), in Poole, A.F., and Gill, F.B., eds., The birds of the world: Ithaca, N.Y., Cornell Lab of Ornithology, accessed July 2021 at https://birdsoftheworld. $\mathrm{org} / \mathrm{bow} / \mathrm{species/graspa/cur/introduction.} \mathrm{[Also} \mathrm{available} \mathrm{at}$ https://doi.org/10.2173/bow.graspa.01.]

Vickery, P.D., Hunter, M.L., Jr., and Melvin, S.M., 1994, Effects of habitat area on the distribution of grassland birds in Maine: Conservation Biology, v. 8, no. 4, p. 10871097. [Also available at https://doi.org/10.1046/j.15231739.1994.08041087.x.]

Vickery, P.D., Hunter, M.L., Jr., and Wells, J.V., 1992, Use of a new reproductive index to evaluate relationship between habitat quality and breeding success: The Auk, v. 109, no. 4, p. 697-705. [Also available at https://doi. org/10.2307/4088145.] 
Vickery, P.D., Hunter, M.L., Jr., and Wells, J.V., 1999, Effects of fire and herbicide treatment on habitat selection in grassland birds in southern Maine, in Vickery, P.D., and Herkert, J.R., eds., Ecology and conservation of grassland birds of the Western Hemisphere: Studies in Avian Biology, v. 19, p. 149-159.

Vold, S.T., Berkeley, L.I., and McNew, L.B., 2019, Effects of livestock grazing management on grassland birds in a northern mixed-grass prairie ecosystem: Rangeland Ecology and Management, v. 72, no. 6, p. 933-945. [Also available at https://doi.org/10.1016/j.rama.2019.08.005.]

Volkert, W.K., 1992, Response of grassland birds to a largescale prairie planting project: Passenger Pigeon, v. 54, no. 3, p. 190-196.

Vos, S.M., and Ribic, C.A., 2011, Grassland bird use of oak barrens and dry prairies in Wisconsin: Natural Areas Journal, v. 31, no. 1, p. 26-33. [Also available at https://doi. org/10.3375/043.031.0104.]

Vos, S.M., and Ribic, C.A., 2013, Nesting success of grassland birds in oak barrens and dry prairies in west central Wisconsin: Northeastern Naturalist, v. 20, no. 1, p. 131-142. [Also available at https://doi.org/10.1656/045.020.0110.]

Walcheck, K.C., 1970, Nesting bird ecology of four plant communities in the Missouri River Breaks, Montana: The Wilson Bulletin, v. 82, no. 4, p. 370-382.

Walk, J.W., and Warner, R.E., 2000, Grassland management for the conservation of songbirds in the midwestern USA: Biological Conservation, v. 94, no. 2, p. 165-172. [Also available at https://doi.org/10.1016/S0006-3207(99)001822.]

Wellicome, T.I., Kardynal, K.J., Franken, R.J., and Gillies, C.S., 2014, Off-road sampling reveals a different grassland bird community than roadside sampling-Implications for survey design and estimates to guide conservation: Avian Conservation and Ecology, v. 9, no. 1, article 4. [Also available at https://doi.org/10.5751/ACE-00624-090104.]

Wentworth, K.L., Brittingham, M.C., and Wilson, A.M., 2010, Conservation Reserve Enhancement Program fields-Benefits for grassland and shrub-scrub species: Journal of Soil and Water Conservation, v. 65, no. 1, p. 50-60. [Also available in https://doi.org/10.2489/jswc.65.1.50.]

Whitmore, R.C., 1979, Temporal variation in the selected habitats of a guild of grassland sparrows: The Wilson Bulletin, v. 91, no. 4, p. 592-598.

Whitmore, R.C., 1980, Reclaimed surface mines as avian habitat islands in the eastern forest: American Birds, v. 34, no. 1 , p. 13-14.
Whitmore, R.C., 1981, Structural characteristics of Grasshopper Sparrow habitat: The Journal of Wildlife Management, v. 45, no. 3, p. 811-814. [Also available at https://doi. org $/ 10.2307 / 3808729$.]

Wiens, J.A., 1969, An approach to the study of ecological relationships among grassland birds: Ornithological Monographs no. 8, p. 1-93. [Also available at https://doi. $\operatorname{org} / 10.2307 / 40166677$.

Wiens, J.A., 1970, Avian populations and patterns of habitat occupancy at the Pawnee site, 1968-1969: Fort Collins, Colo., Colorado State University, U.S. International Biological Program, Grassland Biome Technical Report 63, 57 p.

Wiens, J.A., 1973, Interterritorial habitat variation in Grasshopper and Savannah sparrows: Ecology, v. 54, no. 4, p. 877-884. [Also available at https://doi. org/10.2307/1935683.]

Wilkins, K., Pejchar, L., and Garvoille, R., 2019, Ecological and social consequences of bison reintroduction in Colorado: Conservation Science and Practice, v. 1, no. 2, e. 9. [Also available at https://doi.org/10.1111/csp2.9.]

Williams, E.J., 2016, Grasshopper Sparrows on the movePatterns and causes of within-season breeding dispersal in a declining grassland songbird: Manhattan, Kans., Kansas State University, Master's Thesis. 132 p.

Williams, E.J., and Boyle, W.A., 2018, Patterns and correlates of within-season breeding dispersal-A common strategy in a declining grassland songbird: The Auk, v. 135, no. 1, p. 1-14. [Also available at https://doi.org/10.1642/AUK-1769.1.]

Williams, E.J., and Boyle, W.A., 2019, Causes and consequences of avian within-season dispersal decisions in a dynamic grassland environment: Animal Behaviour, v. 155, p. 77-87. [Also available at https://doi.org/10.1016/j.anbehav.2019.06.009.]

Wilsey, C., Taylor, L., Bateman, B., Jensen, C., Michel, N., Panjabi, A., and Langham, G., 2019, Climate policy action needed to reduce vulnerability of conservation-reliant grassland birds in North America: Conservation Science and Practice, v. 1, no. 4, p. e21. [Also available at https://doi. org/10.1111/csp2.21.]

Wilson, S.D., and Belcher, J.W., 1989, Plant and bird communities of native prairie and introduced Eurasian vegetation in Manitoba, Canada: Conservation Biology, v. 3, no. 1, p. 39-44. [Also available at https://doi. org/10.1111/j.1523-1739.1989.tb00222.x.]

Winnicki, S.K., Munguía, S.M., Williams, E., and Boyle, A., 2020, Social interactions do not drive territory aggregation in a grassland songbird: Ecology, v. 101, no. 2, p. e02927. [Also available at https://doi.org/10.1002/ecy.2927.] 
Winter, M., 1998, Effect of habitat fragmentation on grassland-nesting birds in southwestern Missouri: Columbia, Mo., University of Missouri, Ph.D. Dissertation, 215 p.

Winter, M., and Faaborg, J., 1999, Patterns of area sensitivity in grassland-nesting birds: Conservation Biology, v. 13, no. 6, p. 1424-1436. [Also available at https://doi. org/10.1046/j.1523-1739.1999.98430.x.]

With, K.A., King, A.W., and Jensen, W.E., 2008, Remaining large grasslands may not be sufficient to prevent grassland bird declines: Biological Conservation, v. 141, no. 12, p. 3152-3167. [Also available at https://doi.org/10.1016/j. biocon.2008.09.025.]

Wood, E.M., Pidgeon, A.M., Gratton, C., and Wilder, T.T., 2011, Effects of oak barrens habitat management for Karner blue butterfly (Lycaeides samuelis) on the avian community: Biological Conservation, v. 144, no. 12, p. 3117-3126. [Also available at https://doi.org/10.1016/j. biocon.2011.10.010.]

Wray, T., II, Strait, K.A., and Whitmore, R.C., 1982, Reproductive success of grassland sparrows on a reclaimed surface mine in West Virginia: The Auk, v. 99, no. 1, p. 157164. [Also available at https://doi.org/10.2307/4086032.]
Wulff, S.J., Butler, M.J., and Ballard, W.B., 2016, Assessment of diurnal wind turbine collision risk for grassland birds on the southern Great Plains: Journal of Fish and Wildlife Management, v. 7, no. 1, p. 129-140. [Also available at https://doi.org/10.3996/042015-JFWM-031.]

Zimmerman, J.L., 1992, Density-independent factors affecting the avian diversity of the tallgrass prairie community: The Wilson Bulletin, v. 104, no. 1, p. 85-94.

Zimmerman, J.L., 1993, Birds of Konza-The avian ecology of the tallgrass prairie: Lawrence, Kans., University of Kansas Press, 186 p.

Zimmerman, J.L., 1997, Avian community responses to fire, grazing, and drought in the tallgrass prairie, in Knopf, F.L., and Samson, F.B., eds., Ecology and conservation of Great Plains vertebrates: New York, N.Y., Springer-Verlag, p. 167-180. [Also available at https://doi.org/10.1007/9781-4757-2703-6_7.]

Zimmerman, J.L., and Finck, E.J., 1983, Success in a secondary habitat - The Dickcissel in the tallgrass prairie, in Brewer, R., ed., Proceedings of the eighth North American Prairie Conference: Kalamazoo, Mich., Western Michigan University, p. 47-49. 
Table GG1. Measured values of vegetation structure and composition in Grasshopper Sparrow (Ammodramus savannarum) breeding habitat by study. The parenthetical descriptors following authorship and year in the "Study" column indicate that the vegetation measurements were taken in locations or under conditions specified in the descriptor; no descriptor implies that measurements were taken within the general study area.

[cm, centimeter; \%, percent; --, no data; CRP, Conservation Reserve Program; <, less than; DNC, dense nesting cover; >, greater than; spp., species]

\begin{tabular}{|c|c|c|c|c|c|c|c|c|c|c|c|}
\hline Study & $\begin{array}{l}\text { State or } \\
\text { province }\end{array}$ & Habitat & $\begin{array}{c}\text { Management } \\
\text { practice or } \\
\text { treatment }\end{array}$ & $\begin{array}{c}\text { Vegetation } \\
\text { height } \\
\text { (cm) }\end{array}$ & $\begin{array}{c}\text { Vegetation } \\
\text { height-density } \\
\text { (cm) }\end{array}$ & $\begin{array}{c}\text { Grass } \\
\text { cover } \\
(\%) \\
\end{array}$ & $\begin{array}{c}\text { Forb } \\
\text { cover } \\
(\%)\end{array}$ & $\begin{array}{c}\text { Shrub } \\
\text { cover } \\
(\%) \\
\end{array}$ & $\begin{array}{c}\text { Bare ground } \\
\text { cover } \\
(\%)\end{array}$ & $\begin{array}{c}\text { Litter } \\
\text { cover } \\
(\%) \\
\end{array}$ & $\begin{array}{l}\text { Litter } \\
\text { depth } \\
(\mathrm{cm})\end{array}$ \\
\hline $\begin{array}{l}\text { Bakker and Higgins, } \\
2009\end{array}$ & $\begin{array}{l}\text { Minnesota, } \\
\text { South } \\
\text { Dakota }\end{array}$ & Tallgrass prairie & -- & $96^{\mathrm{a}}$ & $20^{\mathrm{b}}$ & -- & -- & -- & -- & -- & 2.6 \\
\hline $\begin{array}{l}\text { Bakker and Higgins, } \\
2009\end{array}$ & $\begin{array}{l}\text { Minnesota, } \\
\text { South } \\
\text { Dakota }\end{array}$ & Tame grassland & $\begin{array}{l}\text { Seeded to intermediate } \\
\text { wheatgrass } \\
\text { (Thinopyrum } \\
\text { intermedium) }\end{array}$ & $135^{\mathrm{a}}$ & $36^{\mathrm{b}}$ & -- & -- & -- & -- & -- & 3.1 \\
\hline $\begin{array}{l}\text { Bakker and Higgins, } \\
2009\end{array}$ & $\begin{array}{l}\text { Minnesota, } \\
\text { South } \\
\text { Dakota }\end{array}$ & Tame grassland & $\begin{array}{l}\text { Seeded to switchgrass } \\
\quad(\text { Panicum virgatum })\end{array}$ & $107^{\mathrm{a}}$ & $37^{\mathrm{b}}$ & -- & -- & -- & -- & -- & 1.6 \\
\hline $\begin{array}{l}\text { Bakker and Higgins, } \\
2009\end{array}$ & $\begin{array}{l}\text { Minnesota, } \\
\text { South } \\
\text { Dakota }\end{array}$ & Tame grassland & $\begin{array}{l}\text { Cool-season seeding } \\
\text { mixture }\end{array}$ & $124^{\mathrm{a}}$ & $36^{\mathrm{b}}$ & -- & -- & -- & -- & -- & 3.4 \\
\hline $\begin{array}{l}\text { Bakker and Higgins, } \\
2009\end{array}$ & $\begin{array}{l}\text { Minnesota, } \\
\text { South } \\
\text { Dakota }\end{array}$ & Tame grassland & $\begin{array}{l}\text { Warm-season } \\
\text { seeding mixture }\end{array}$ & $166^{\mathrm{a}}$ & $27^{\mathrm{b}}$ & -- & -- & -- & -- & -- & 4.1 \\
\hline $\begin{array}{l}\text { Balent and Norment, } \\
2003\end{array}$ & New York & Multiple & -- & -- & $17-24.8^{\mathrm{b}}$ & -- & -- & -- & -- & -- & -- \\
\hline Bock and Webb, 1984 & Arizona & Semidesert grassland & Grazed, ungrazed & $30^{\mathrm{a}}$ & -- & 72.2 & 4.3 & 4.7 & 22.9 & -- & -- \\
\hline $\begin{array}{l}\text { Dieni and Jones, } 2003 \\
\text { (nests) }\end{array}$ & Montana & Mixed-grass prairie & Idle & 32.5 & $13^{\mathrm{b}}$ & 56.2 & 12.2 & 0.8 & 0.4 & 6.1 & 9.4 \\
\hline $\begin{array}{l}\text { Dieni and Jones, } 2003 \\
\text { (nest vicinity) }\end{array}$ & Montana & Mixed-grass prairie & Idle & 23.6 & $9^{b}$ & -- & -- & -- & -- & -- & -- \\
\hline $\begin{array}{l}\text { Fletcher and Koford, } \\
2002\end{array}$ & Iowa & Tallgrass prairie & -- & 91.7 & -- & 45.6 & 33.4 & -- & 0.9 & 9.9 & 3.4 \\
\hline $\begin{array}{l}\text { Fletcher and Koford, } \\
2002\end{array}$ & Iowa & Restored grassland & $\begin{array}{l}\text { Cool- and warm- } \\
\text { season seeding } \\
\text { mixture }\end{array}$ & 91.6 & -- & 51.8 & 20.6 & -- & 3.6 & 13.7 & 2.5 \\
\hline $\begin{array}{l}\text { Fritcher and others, } \\
\qquad 2004^{\mathrm{c}, \mathrm{d}}\end{array}$ & South Dakota & Mixed-grass prairie & Grazed & $26.6-51.8$ & $5.8-17^{\mathrm{b}}$ & $85.7-91.6$ & $18-26.1$ & -- & $1.8-12.9$ & $80.7-94.6$ & $0.9-3.1$ \\
\hline $\begin{array}{l}\text { Fuhlendorf and others, } \\
2006^{\mathrm{e}}\end{array}$ & Oklahoma & Tallgrass prairie & $\begin{array}{l}\text { Annual complete burn } \\
\text { and grazed }\end{array}$ & 14.7 & -- & 63 & 18 & -- & 20.3 & 8 & -- \\
\hline
\end{tabular}


Table GG1. Measured values of vegetation structure and composition in Grasshopper Sparrow (Ammodramus savannarum) breeding habitat by study. The parenthetical descriptors following authorship and year in the "Study" column indicate that the vegetation measurements were taken in locations or under conditions specified in the descriptor; no descriptor implies that measurements were taken within the general study area.-Continued

[cm, centimeter; \%, percent; --, no data; CRP, Conservation Reserve Program; <, less than; DNC, dense nesting cover; >, greater than; spp., species]

\begin{tabular}{|c|c|c|c|c|c|c|c|c|c|c|c|}
\hline Study & $\begin{array}{l}\text { State or } \\
\text { province }\end{array}$ & Habitat & $\begin{array}{c}\text { Management } \\
\text { practice or } \\
\text { treatment }\end{array}$ & $\begin{array}{l}\text { Vegetation } \\
\text { height } \\
\text { (cm) }\end{array}$ & $\begin{array}{l}\text { Vegetation } \\
\text { height-density } \\
\text { (cm) }\end{array}$ & $\begin{array}{c}\text { Grass } \\
\text { cover } \\
(\%)\end{array}$ & $\begin{array}{c}\text { Forb } \\
\text { cover } \\
(\%)\end{array}$ & $\begin{array}{c}\text { Shrub } \\
\text { cover } \\
(\%)\end{array}$ & $\begin{array}{c}\text { Bare ground } \\
\text { cover } \\
(\%)\end{array}$ & $\begin{array}{c}\text { Litter } \\
\text { cover } \\
(\%)\end{array}$ & $\begin{array}{l}\text { Litter } \\
\text { depth } \\
\text { (cm) }\end{array}$ \\
\hline $\begin{array}{l}\text { Fuhlendorf and others, } \\
2006^{\mathrm{e}}\end{array}$ & Oklahoma & Tallgrass prairie & Patch-burn and grazed & 21.7 & -- & 55.7 & 19 & -- & 14.7 & 50.3 & -- \\
\hline $\begin{array}{l}\text { Giuliano and Daves, } \\
2002\end{array}$ & Pennsylvania & Tame grassland & $\begin{array}{l}\text { Warm-season } \\
\text { seeding mixture }\end{array}$ & $43.6-133.5$ & -- & -- & -- & -- & -- & -- & -- \\
\hline $\begin{array}{l}\text { Giuliano and Daves, } \\
2002\end{array}$ & Pennsylvania & Tame grassland & $\begin{array}{l}\text { Cool-season seeding } \\
\text { mixture }\end{array}$ & $26.1-82.6$ & -- & -- & -- & -- & -- & -- & -- \\
\hline Grant and others, 2004 & North Dakota & Mixed-grass prairie & -- & 44 & -- & -- & -- & 12.2 & -- & -- & 3.5 \\
\hline Greer, $2009^{d}$ & South Dakota & Mixed-grass prairie & Multiple & $78^{\mathrm{a}}$ & $13^{\mathrm{b}}$ & 55 & 20 & 1.5 & 7.8 & 17.6 & 1.2 \\
\hline Guido, 2020 (nests) & $\begin{array}{l}\text { Montana, North } \\
\text { Dakota }\end{array}$ & Mixed-grass prairie & Grazed & 22 & $10^{\mathrm{b}}$ & 22 & 7 & 0 & 5 & 15 & -- \\
\hline $\begin{array}{l}\text { Guido, } 2020 \text { (juvenile } \\
\text { locations) }\end{array}$ & $\begin{array}{l}\text { Montana, North } \\
\text { Dakota }\end{array}$ & Mixed-grass prairie & Grazed & 29 & -- & 12 & 20 & 2 & 10 & 5 & -- \\
\hline $\begin{array}{l}\text { Harrison, } 1974 \\
\quad \text { (territories) }\end{array}$ & Michigan & Tame grassland & Hayed & 48.4 & -- & -- & -- & -- & -- & 60.5 & -- \\
\hline $\begin{array}{l}\text { Hickman and others, } \\
2006\end{array}$ & Kansas & Tallgrass prairie & Grazed & 31.7 & -- & 54 & 38.1 & -- & -- & -- & 1.2 \\
\hline $\begin{array}{l}\text { Hickman and others, } \\
2006\end{array}$ & Kansas & Expired CRP & Grazed & 31.9 & -- & 68 & 13.9 & -- & -- & -- & 3.3 \\
\hline $\begin{array}{l}\text { Hickman and others, } \\
2006\end{array}$ & Kansas & Tame grassland & Grazed & 29.6 & -- & 42.5 & 21.2 & -- & -- & -- & 1 \\
\hline $\begin{array}{l}\text { Hubbard and others, } \\
2006 \text { (nest sites) }\end{array}$ & Kansas & $\begin{array}{l}\text { Tallgrass prairie, tame } \\
\text { grassland }\end{array}$ & Multiple & -- & $30^{\mathrm{b}}$ & -- & -- & -- & -- & -- & 3.6 \\
\hline Jensen, 1999 (nests) & Kansas & Tallgrass prairie & Multiple & $0.7-32.5^{\mathrm{f}}$ & -- & 53.4 & 12.6 & 0.2 & 15.7 & 16.7 & -- \\
\hline $\begin{array}{l}\text { Jensen, } 1999 \text { (nest } \\
\text { vicinity) }\end{array}$ & Kansas & Tallgrass prairie & Multiple & $0.1-31.7^{f}$ & -- & 48.5 & 11.7 & $<1$ & 25.4 & 12.7 & -- \\
\hline Kalyn Bogard, 2011 & Saskatchewan & Mixed-grass prairie & Grazed & 11.1 & -- & 58.5 & 11.1 & -- & 27.6 & -- & 0.2 \\
\hline $\begin{array}{l}\text { Lueders and others, } \\
2006\end{array}$ & North Dakota & Mixed-grass prairie & Cattle-grazed & -- & $8^{\mathrm{b}}$ & $29.1^{\mathrm{g}}$ & 11 & 0.6 & 24.7 & 25.9 & 1.5 \\
\hline $\begin{array}{l}\text { Lueders and others, } \\
2006\end{array}$ & North Dakota & Mixed-grass prairie & $\begin{array}{l}\text { American bison (Bison } \\
\text { bison)-grazed }\end{array}$ & -- & $18^{\mathrm{b}}$ & $29^{\mathrm{g}}$ & 11.8 & 10.4 & 9.5 & 36.7 & 3.1 \\
\hline Madden, 1996 & North Dakota & Mixed-grass prairie & Burned & -- & $16^{\mathrm{b}}$ & 40.8 & 25.6 & 20.5 & -- & -- & 3.8 \\
\hline
\end{tabular}

Madden, 1996 Mixed-grass prairie Burned 
Table GG1. Measured values of vegetation structure and composition in Grasshopper Sparrow (Ammodramus savannarum) breeding habitat by study. The parenthetical descriptors following authorship and year in the "Study" column indicate that the vegetation measurements were taken in locations or under conditions specified in the descriptor; no descriptor implies that measurements were taken within the general study area.-Continued

[cm, centimeter; \%, percent; --, no data; CRP, Conservation Reserve Program; <, less than; DNC, dense nesting cover; >, greater than; spp., species]

\begin{tabular}{|c|c|c|c|c|c|c|c|c|c|c|c|}
\hline Study & $\begin{array}{l}\text { State or } \\
\text { province }\end{array}$ & Habitat & $\begin{array}{c}\text { Management } \\
\text { practice or } \\
\text { treatment }\end{array}$ & $\begin{array}{l}\text { Vegetation } \\
\text { height } \\
\text { (cm) }\end{array}$ & $\begin{array}{c}\text { Vegetation } \\
\text { height-density } \\
\text { (cm) }\end{array}$ & $\begin{array}{c}\text { Grass } \\
\text { cover } \\
(\%)\end{array}$ & $\begin{array}{c}\text { Forb } \\
\text { cover } \\
(\%)\end{array}$ & $\begin{array}{c}\text { Shrub } \\
\text { cover } \\
(\%)\end{array}$ & $\begin{array}{c}\text { Bare ground } \\
\text { cover } \\
(\%)\end{array}$ & $\begin{array}{c}\text { Litter } \\
\text { cover } \\
(\%)\end{array}$ & $\begin{array}{r}\text { Litter } \\
\text { depth } \\
\text { (cm) }\end{array}$ \\
\hline $\begin{array}{l}\text { McCoy and others, } \\
2001^{\mathrm{d}}\end{array}$ & Missouri & $\begin{array}{l}\text { Tame grassland } \\
\text { (CRP) }\end{array}$ & $\begin{array}{l}\text { Cool-season seeding } \\
\text { mixture }\end{array}$ & -- & $51^{\mathrm{b}}$ & 46 & 33 & 1 & 12 & 75 & 2.6 \\
\hline $\begin{array}{l}\text { McCoy and others, } \\
2001^{\mathrm{d}}\end{array}$ & Missouri & $\begin{array}{l}\text { Tame grassland } \\
\text { (CRP) }\end{array}$ & $\begin{array}{l}\text { Warm-season seeding } \\
\text { mixture }\end{array}$ & -- & $80^{\mathrm{b}}$ & 54 & 27 & $<1$ & 11 & 74 & 2.2 \\
\hline Murray and Best, 2003 & Iowa & $\begin{array}{l}\text { Tame grassland } \\
\text { (CRP) }\end{array}$ & $\begin{array}{l}\text { Total-harvested } \\
\text { switchgrass }\end{array}$ & 80.9 & $71^{\mathrm{b}}$ & 51.6 & 19.6 & 0.4 & 5 & 23.2 & 1.9 \\
\hline Murray and Best, 2003 & Iowa & $\begin{array}{l}\text { Tame grassland } \\
\text { (CRP) }\end{array}$ & $\begin{array}{l}\text { Strip-harvested } \\
\text { switchgrass }\end{array}$ & 81.7 & $75^{b}$ & 53.3 & 17.5 & 0.1 & 2.8 & 29.6 & 3.5 \\
\hline Murray and Best, 2003 & Iowa & $\begin{array}{l}\text { Tame grassland } \\
\quad(\mathrm{CRP})\end{array}$ & $\begin{array}{l}\text { Unharvested } \\
\text { switchgrass }\end{array}$ & 78.1 & $71^{\mathrm{b}}$ & 32.9 & 25.4 & 2.1 & 2.9 & 22.9 & 5.5 \\
\hline $\begin{array}{l}\text { Negus and others, } \\
2010^{\mathrm{d}}\end{array}$ & Nebraska & $\begin{array}{l}\text { Tame grassland } \\
\text { (CRP) }\end{array}$ & $\begin{array}{l}\text { Disked and } \\
\text { interseeded }\end{array}$ & 65.7 & $35.8^{\mathrm{b}}$ & 41.8 & 23.8 & -- & 14.5 & 25.2 & 1.7 \\
\hline $\begin{array}{l}\text { Negus and others, } \\
2010^{\mathrm{d}}\end{array}$ & Nebraska & $\begin{array}{l}\text { Tame grassland } \\
\text { (CRP) }\end{array}$ & Idle & 55.9 & $29.4^{\mathrm{b}}$ & 63.9 & 1.4 & -- & 1.4 & 39.3 & 3.1 \\
\hline $\begin{array}{l}\text { Osborne and Sparling, } \\
2013^{\mathrm{d}}\end{array}$ & Illinois & $\begin{array}{l}\text { Tame grassland } \\
\text { (CRP) }\end{array}$ & Idle & -- & $56.5^{\mathrm{b}}$ & 47.4 & 23.3 & -- & 8.5 & -- & 6.0 \\
\hline $\begin{array}{l}\text { Osborne and Sparling, } \\
2013^{\mathrm{d}}\end{array}$ & Illinois & $\begin{array}{l}\text { Tame grassland } \\
\text { (CRP) }\end{array}$ & Disked & -- & $52^{\mathrm{b}}$ & 47.7 & 22.5 & -- & 16.1 & -- & 5.4 \\
\hline $\begin{array}{l}\text { Osborne and Sparling, } \\
2013^{\mathrm{d}}\end{array}$ & Illinois & $\begin{array}{l}\text { Tame grassland } \\
\text { (CRP) }\end{array}$ & Glyphosphate-sprayed & -- & $56.7^{\mathrm{b}}$ & 23.8 & 37.5 & -- & 12.9 & -- & 4.1 \\
\hline $\begin{array}{l}\text { Osborne and Sparling, } \\
2013^{\mathrm{d}}\end{array}$ & Illinois & $\begin{array}{l}\text { Tame grassland } \\
\text { (CRP) }\end{array}$ & $\begin{array}{l}\text { Glyphosate-sprayed } \\
\text { and seeded }\end{array}$ & -- & $53.7^{\mathrm{b}}$ & 29.3 & 31.3 & -- & 15.5 & -- & 3.6 \\
\hline $\begin{array}{l}\text { Patterson and Best, } \\
1996 \text { (nests) }\end{array}$ & Iowa & $\begin{array}{l}\text { Tame grassland } \\
\text { (CRP) }\end{array}$ & $\begin{array}{l}\text { Idle with some spot } \\
\text { mowing }\end{array}$ & 45 & $24^{b}$ & 95 & 7 & -- & -- & -- & -- \\
\hline $\begin{array}{l}\text { Piehler, } 1987^{\mathrm{h}} \\
\quad \text { (territories) }\end{array}$ & Pennsylvania & $\begin{array}{l}\text { Reclaimed mine } \\
\text { grassland }\end{array}$ & -- & 75.5 & $99.5^{\mathrm{i}}$ & -- & 27.6 & 0.3 & 33.8 & 66.2 & 2.2 \\
\hline Pillsbury, $2010^{d}$ & Iowa, Missouri & $\begin{array}{l}\text { Restored native } \\
\text { grassland }\end{array}$ & Multiple & -- & $44.6^{\mathrm{b}}$ & 21.7 & 24.8 & 2.3 & -- & 32.1 & -- \\
\hline $\begin{array}{l}\text { Renfrew and Ribic, } \\
2002\end{array}$ & Wisconsin & $\begin{array}{l}\text { Tame lowland } \\
\text { grassland }\end{array}$ & Grazed & -- & $8.4^{\mathrm{b}}$ & -- & -- & -- & 34.9 & -- & 1 \\
\hline $\begin{array}{l}\text { Renfrew and Ribic, } \\
2002\end{array}$ & Wisconsin & $\begin{array}{l}\text { Tame upland } \\
\text { grassland }\end{array}$ & Grazed & -- & $9.9^{\mathrm{b}}$ & -- & -- & -- & 26.1 & -- & 1.1 \\
\hline
\end{tabular}


Table GG1. Measured values of vegetation structure and composition in Grasshopper Sparrow (Ammodramus savannarum) breeding habitat by study. The parenthetical descriptors following authorship and year in the "Study" column indicate that the vegetation measurements were taken in locations or under conditions specified in the descriptor; no descriptor implies that measurements were taken within the general study area.-Continued

[cm, centimeter; \%, percent; --, no data; CRP, Conservation Reserve Program; <, less than; DNC, dense nesting cover; >, greater than; spp., species]

\begin{tabular}{|c|c|c|c|c|c|c|c|c|c|c|c|}
\hline Study & $\begin{array}{l}\text { State or } \\
\text { province }\end{array}$ & Habitat & $\begin{array}{l}\text { Management } \\
\text { practice or } \\
\text { treatment }\end{array}$ & $\begin{array}{l}\text { Vegetation } \\
\text { height } \\
\text { (cm) }\end{array}$ & $\begin{array}{l}\text { Vegetation } \\
\text { height-density } \\
\text { (cm) }\end{array}$ & $\begin{array}{c}\text { Grass } \\
\text { cover } \\
(\%)\end{array}$ & $\begin{array}{l}\text { Forb } \\
\text { cover } \\
(\%)\end{array}$ & $\begin{array}{l}\text { Shrub } \\
\text { cover } \\
(\%)\end{array}$ & $\begin{array}{l}\text { Bare ground } \\
\text { cover } \\
(\%)\end{array}$ & $\begin{array}{l}\text { Litter } \\
\text { cover } \\
(\%)\end{array}$ & $\begin{array}{l}\text { Litter } \\
\text { depth } \\
(\mathrm{cm})\end{array}$ \\
\hline $\begin{array}{l}\text { Renfrew and Ribic, } \\
2008\end{array}$ & Wisconsin & Tame grassland & Grazed & -- & $9^{b}$ & -- & 31.8 & -- & 37.6 & -- & -- \\
\hline Renken, $1983^{\mathrm{h}}$ & North Dakota & $\begin{array}{l}\text { Tame grassland } \\
\text { (DNC) }\end{array}$ & Idle, grazed & -- & $40^{\mathrm{b}}$ & 62.4 & 26.4 & 6.9 & 0.4 & 99.1 & 2.8 \\
\hline Roth and others, 2005 & Wisconsin & $\begin{array}{l}\text { Tame grassland } \\
\quad(\mathrm{CRP})\end{array}$ & $\begin{array}{l}\text { Unharvested } \\
\text { switchgrass }\end{array}$ & -- & $56.8^{\mathrm{b}}$ & -- & 39.2 & -- & -- & -- & 3.1 \\
\hline Roth and others, 2005 & Wisconsin & $\begin{array}{l}\text { Tame grassland } \\
\text { (CRP) }\end{array}$ & $\begin{array}{l}\text { Harvested } \\
\text { switchgrass }\end{array}$ & -- & $12.4^{\mathrm{b}}$ & -- & 33.2 & -- & -- & -- & 1.4 \\
\hline $\begin{array}{l}\text { Ruth and Skagen, } 2017 \\
\text { (territories) }\end{array}$ & Arizona & Desert grassland & Multiple & -- & $4-14^{b}$ & -- & -- & -- & -- & -- & -- \\
\hline $\begin{array}{l}\text { Ruth and Skagen, } 2017 \\
\text { (nests) }\end{array}$ & Arizona & Desert grassland & Multiple & -- & $5-12^{b}$ & -- & -- & -- & -- & -- & -- \\
\hline Salo and others, 2004 & North Dakota & Mixed-grass prairie & $\begin{array}{l}\text { Light grazing } \\
\text { intensity }\end{array}$ & $52.9^{\mathrm{a}}$ & $50.3^{\mathrm{b}}$ & -- & -- & -- & -- & -- & 5.3 \\
\hline Salo and others, 2004 & North Dakota & Mixed-grass prairie & $\begin{array}{l}\text { Moderate grazing } \\
\text { intensity }\end{array}$ & $48.3^{\mathrm{a}}$ & $45.8^{\mathrm{b}}$ & -- & -- & -- & -- & -- & 4.6 \\
\hline Salo and others, 2004 & North Dakota & Mixed-grass prairie & $\begin{array}{l}\text { Heavy grazing } \\
\text { intensity }\end{array}$ & $27.1^{\mathrm{a}}$ & $22.9^{\mathrm{b}}$ & -- & -- & -- & -- & -- & 2 \\
\hline Salo and others, 2004 & North Dakota & Mixed-grass prairie & $\begin{array}{l}\text { Extreme grazing } \\
\text { intensity }\end{array}$ & $17.5^{\mathrm{a}}$ & $7.9^{\mathrm{b}}$ & -- & -- & -- & -- & -- & 0.9 \\
\hline Sample, 1989 & Wisconsin & Multiple & -- & 57.5 & $14^{\mathrm{b}}$ & -- & $76.2^{\mathrm{j}}$ & 3.2 & 7.8 & 12.4 & -- \\
\hline $\begin{array}{l}\text { Scheiman and others, } \\
2003 \text { (nests) }\end{array}$ & North Dakota & Tallgrass prairie & Multiple & -- & $14^{\mathrm{b}}$ & 38.5 & 13.2 & -- & 3.7 & 36.8 & 2.4 \\
\hline Schneider, 1998 & North Dakota & Mixed-grass prairie & Grazed & -- & $10.5^{\mathrm{b}}$ & 43.1 & 14.9 & -- & 2.8 & -- & 2.5 \\
\hline Sliwinski, 2011 & Saskatchewan & Mixed-grass prairie & $\begin{array}{l}\text { Bison- and cattle- } \\
\text { grazed }\end{array}$ & 30.8 & -- & 29.9 & 4.9 & -- & 1.4 & 34.3 & 4.7 \\
\hline $\begin{array}{l}\text { Small and others, } 2015 \\
\text { (dependent juvenile } \\
\text { locations) }\end{array}$ & Maryland & $\begin{array}{l}\text { Warm-season grass- } \\
\text { land (CRP) }\end{array}$ & Burned and sprayed & 108.5 & $32.5^{\mathrm{b}}$ & 31.8 & 26.2 & -- & 11.5 & 27 & 1.9 \\
\hline $\begin{array}{l}\text { Small and others, } 2015 \\
\text { (independent } \\
\text { juvenile locations) }\end{array}$ & Maryland & $\begin{array}{l}\text { Warm-season grass- } \\
\text { land (CRP) }\end{array}$ & Burned and sprayed & 98.8 & $30.7^{\mathrm{b}}$ & 17.3 & 18.5 & -- & 27.5 & 28.7 & 1.9 \\
\hline Smith, 1968 & Rangewide & Multiple & -- & -- & -- & -- & -- & $<35$ & -- & -- & -- \\
\hline
\end{tabular}

Rangewide Multiple 
Table GG1. Measured values of vegetation structure and composition in Grasshopper Sparrow (Ammodramus savannarum) breeding habitat by study. The parenthetical descriptors following authorship and year in the "Study" column indicate that the vegetation measurements were taken in locations or under conditions specified in the descriptor; no descriptor implies that measurements were taken within the general study area.-Continued

[cm, centimeter; \%, percent; --, no data; CRP, Conservation Reserve Program; <, less than; DNC, dense nesting cover; >, greater than; spp., species]

\begin{tabular}{|c|c|c|c|c|c|c|c|c|c|c|c|}
\hline Study & $\begin{array}{l}\text { State or } \\
\text { province }\end{array}$ & Habitat & $\begin{array}{c}\text { Management } \\
\text { practice or } \\
\text { treatment }\end{array}$ & $\begin{array}{l}\text { Vegetation } \\
\text { height } \\
\text { (cm) }\end{array}$ & $\begin{array}{c}\text { Vegetation } \\
\text { height-density } \\
\text { (cm) }\end{array}$ & $\begin{array}{c}\text { Grass } \\
\text { cover } \\
(\%)\end{array}$ & $\begin{array}{c}\text { Forb } \\
\text { cover } \\
(\%)\end{array}$ & $\begin{array}{c}\text { Shrub } \\
\text { cover } \\
(\%)\end{array}$ & $\begin{array}{c}\text { Bare ground } \\
\text { cover } \\
(\%)\end{array}$ & $\begin{array}{c}\text { Litter } \\
\text { cover } \\
(\%)\end{array}$ & $\begin{array}{l}\text { Litter } \\
\text { depth } \\
\text { (cm) }\end{array}$ \\
\hline Vold and others, 2019 & $\begin{array}{l}\text { Montana, North } \\
\text { Dakota }\end{array}$ & Mixed-grass prairie & Grazed & $15^{\mathrm{a}}$ & -- & -- & -- & -- & 10 & -- & 3 \\
\hline $\begin{array}{l}\text { Whitmore, } 1979^{\mathrm{k}} \\
\text { (territories) }\end{array}$ & West Virginia & $\begin{array}{l}\text { Reclaimed mine } \\
\text { grassland }\end{array}$ & Early breeding season & $8.1^{1}$ & $31^{\mathrm{i}}$ & 29.4 & 9.6 & -- & 25.6 & 72.9 & 2.1 \\
\hline $\begin{array}{l}\text { Whitmore, } 1979^{\mathrm{k}} \\
\text { (territories) }\end{array}$ & West Virginia & $\begin{array}{l}\text { Reclaimed mine } \\
\text { grassland }\end{array}$ & Peak breeding season & $13.6^{1}$ & $65.4^{\mathrm{i}}$ & 5.3 & 16.9 & -- & 13.9 & 86 & 1.5 \\
\hline $\begin{array}{l}\text { Whitmore, } 1981^{\mathrm{k}} \\
\quad \text { (territories) }\end{array}$ & West Virginia & $\begin{array}{l}\text { Reclaimed mine } \\
\text { grassland }\end{array}$ & -- & 43.8 & $73.4^{\mathrm{i}}$ & 25.7 & 24.7 & 0.7 & 21.9 & 72.5 & 2.4 \\
\hline Wiens, $1969^{\mathrm{h}}$ (nests) & Wisconsin & Tame grassland & Multiple & -- & -- & 98 & 29 & -- & 0 & -- & -- \\
\hline $\begin{array}{l}\text { Wiens, } 1969^{\mathrm{h}} \\
\text { (territories) }\end{array}$ & Wisconsin & Tame grassland & Multiple & -- & -- & 96 & 30 & -- & 2 & -- & -- \\
\hline $\begin{array}{l}\text { Wiens, } 1970^{\mathrm{h}} \\
\quad \text { (territories) }\end{array}$ & Colorado & Shortgrass prairie & $\begin{array}{l}\text { Heavy winter- } \\
\text { grazing intensity }\end{array}$ & -- & $0.5^{\mathrm{i}}$ & 87 & 0 & 0 & 12 & 34.4 & 0.4 \\
\hline Wiens, $1973^{\mathrm{h}}$ & Oklahoma & Shortgrass prairie & -- & $15.2^{\mathrm{m}}$ & $7.2^{\mathrm{i}}$ & 95 & 20 & 0 & 0 & 57 & 1.2 \\
\hline
\end{tabular}

${ }^{a}$ Mean grass height.

${ }^{b}$ Visual obstruction reading (Robel and others, 1970).

${ }^{\mathrm{c} R a n g e s}$ represent averages across seral stages within study area.

${ }^{\mathrm{d}}$ The sum of the percentages is $>100 \%$, based on methods described by the author(s).

eThe sum of the percentages is $>100 \%$, based on the modified point-quadrat technique as described by the author(s).

fRanges encompass the average heights of live grass, dead grass, live forb, and woody plants.

${ }^{g}$ Grass and sedge (Carex spp.) combined.

${ }^{\text {h}}$ The sum of the percentages is $>100 \%$, based on the modified point-quadrat technique of Wiens (1969).

${ }^{i}$ Effective vegetation height.

${ }^{\mathrm{j} H e r b a c e o u s ~ v e g e t a t i o n ~ c o v e r . ~}$

${ }^{k}$ The sum of the percentages is $>100 \%$, based on unclear methods.

'Forb height

memergent vegetation height. 

For more information about this publication, contact: Director, USGS Northern Prairie Wildlife Research Center 8711 37th Street Southeast Jamestown, ND 58401

701-253-5500

For additional information, visit: https://www.usgs.gov/centers/npwrc Publishing support provided by the Rolla Publishing Service Center 
